\title{
Mechanochemical Preparation and Structural \\ Characterization of Layered Double Hydroxides and their Amino Acid-Intercalated Derivatives
}

\author{
PhD Dissertation
}

\section{Zsolt Ferencz}

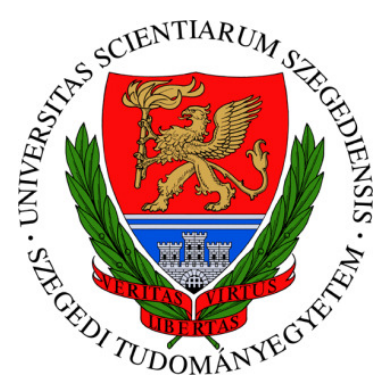

Supervisors:

Dr. István Pálinkó

Dr. Pál Sipos

Doctoral School of Chemistry

Material and Solution Structure Research Group

Department of Organic Chemistry

Faculty of Science and Informatics | University of Szeged

Szeged

2016 


\section{Table of content}

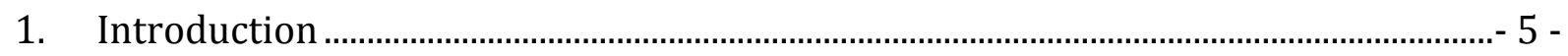

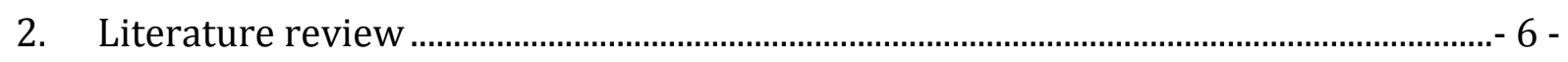

2.1 Structure of the LDHs ....................................................................................................... 7 -

2.1.1 Structure of the layers .......................................................................................- 7 -

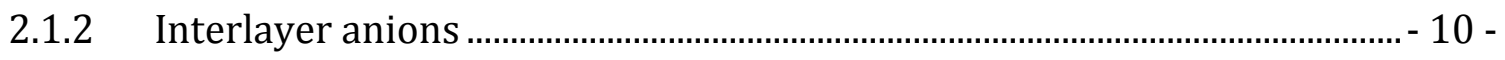

2.2 Aluminum-, iron- and tin-based layered double hydroxides...............................- 13 -

2.3 Preparation and intercalation methods ................................................................. - 15 -

2.3.1 The co-precipitation method …………………………………………………….... - 15 -

2.3.2 The urea hydrolysis method ………………………………………………….... - 17 -

2.3.3 Direct anion-exchange method............................................................................ - 18 -

2.3.4 Dehydration-rehydration method ..................................................................... - 19 -

2.3.5 Mechanochemical method ........................................................................................ - 21 -

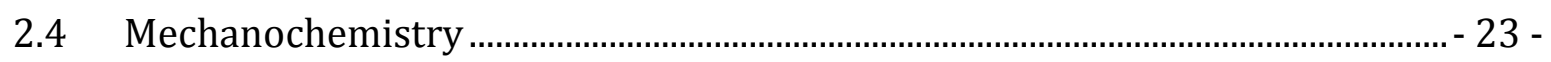

2.4.1 The history of mechanochemistry …………………………………………..... - 24 -

2.4.2 Mechanochemical tools............................................................................................ -25 -

2.4.3 Theories and models................................................................................................ 2 -

2.4.3.1 Hot-spot theory …………………………………………………………….... - 27 -

2.4.3.2 Magma-Plasma Model.....................................................................................- 28 -

2.4.3.3 The hierarchic model ........................................................................................ - 28 -

2.4.3.4 Dislocation and phonon theory.................................................................. - 29 -

2.4.3.5 Theory of short-live active centers............................................................ - 29 -

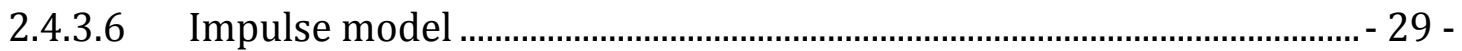

2.4.4 Mechanical activation ........................................................................................... - 30 -

2.4.5 Mechanochemical reactions............................................................................ - 31 -

2.5 Application of LDHs ..................................................................................................- 55 -

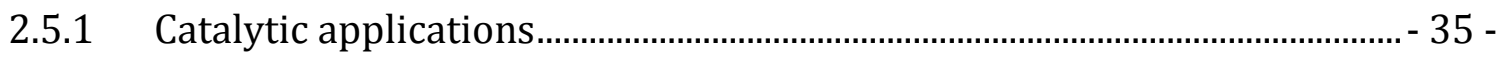


2.5.2 Environmental applications. $-37-$

2.5.3 Pharmaceutical and cosmetic applications .................................................... 38 -

2.5.4 Applications in the polymer industry................................................................ 40 -

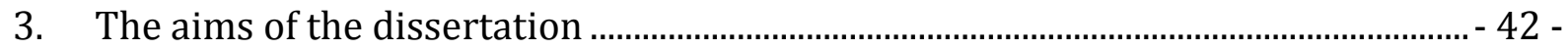

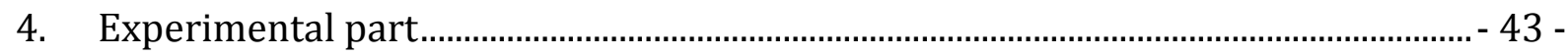

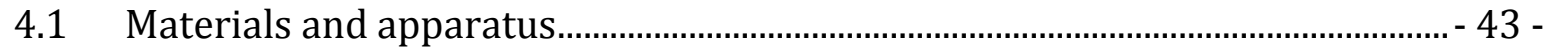

4.2 Preparation of concentrated and carbonate-free $\mathrm{NaOH}$ solution ......................... 43 -

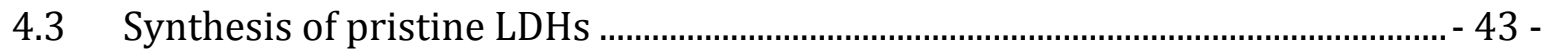

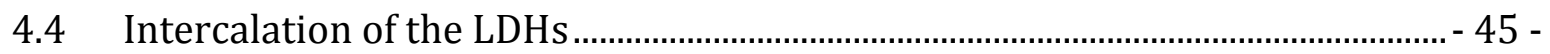

4.5 Instrumentation and characterization methods..................................................... $45-$

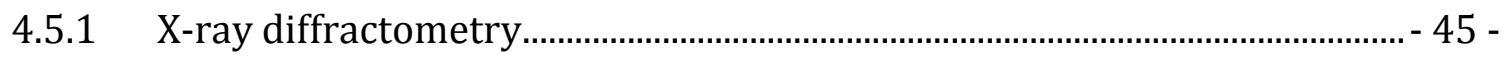

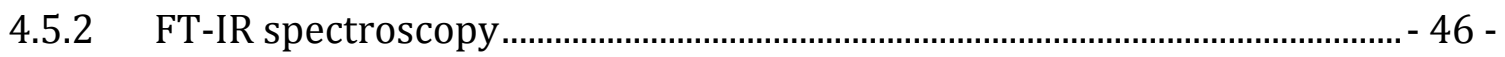

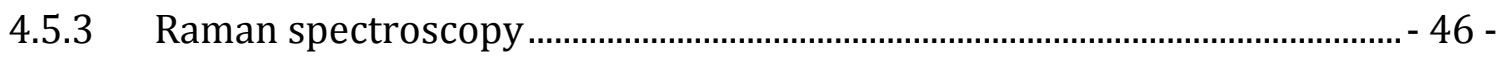

4.5.4 Thermal analytical measurements .................................................................. 46 -

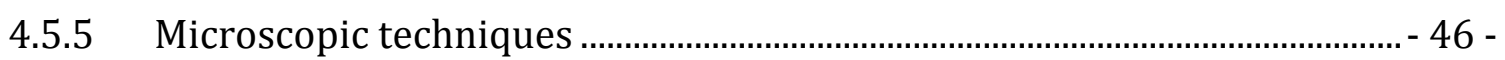

4.5.6 X-ray absorption spectroscopy ....................................................................... 4 -

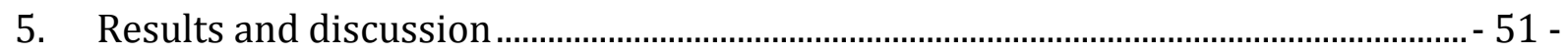

5.1 Preparation of Sn(IV) containing LDHs............................................................... - 51 -

5.2 Preparation of pristine Ca(II)Al(III)- and Ca(II)Fe(III)-LDHs............................. - 55 -

5.3 Intercalation of amino acid anions........................................................................ 70

5.3.1 Intercalation of cystine and valine anions into Ca(II)Sn(IV)-LDHs ...........- 70 -

5.3.2 Intercalation of cystine and tyrosine into Ca(II)Fe(III)-LDHs ..................... - 74 -

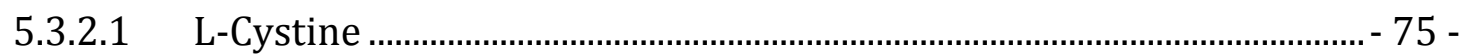

5.3.2.2 L-Tyrosine ............................................................................................... 82 -

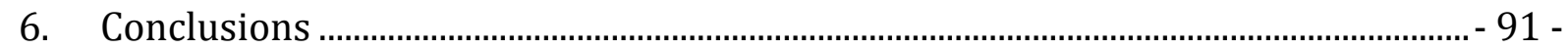

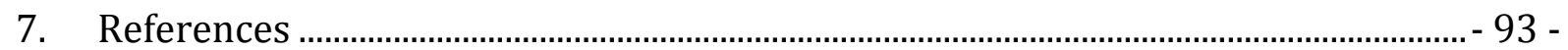

Magyar összefoglaló (Summary in Hungarian) ……………...................................................... - 99 - 
Acknowledgement..

$101-$

$-4-$ 


\section{INTRODUCTION}

Layered double hydroxides, compounds, which can be found in nature as minerals, and can also be synthesized, are currently generating an increasing attention among scientists. Due their unique structure, these synthetic inorganic materials exhibit a set of properties making them suitable for applications in several different advanced technological processes; nevertheless, their main application area is in catalysis, either as catalyst supports or as the actual catalyst. For their syntheses and post-synthesis modifications, various well-established solution-based methods have been developed. In this work a rarely used method is applied for the preparation and the modification of layered double hydroxides, mechanochemistry that is. Using this method, new type of pristine and composite layered double hydroxides could be synthesized besides the already known substances. 


\section{LITERATURE REVIEW}

Layered double hydroxides (LDHs) belong to a group of clay-like materials. Due to the fact that they incorporate various anions, they are also called anionic clays. Many of their representatives can be found in nature; however, for applications they are usually synthesized. This family of materials is represented by the first natural mineral discovered in Sweden in 1842 the hydrotalcite ${ }^{[1]}$. The name reflects the high water content (hydro-) and its resemblance to talc. This compound has a formula of $\mathrm{Mg}_{6} \mathrm{Al}_{2}(\mathrm{OH})_{16} \mathrm{CO}_{3} \cdot 4 \mathrm{H}_{2} \mathrm{O}$. Given that hydrotalcite is the most representative mineral of its group, LDHs are frequently regarded as "hydrotalcite-like compounds (HTlc)".

Regarding its structure, hydrotalcite is related to brucite, in which the $\mathrm{Mg}^{2+}$ ions are octahedrally surrounded by hydroxide ions to form infinite layers of $\mathrm{Mg}(\mathrm{OH})_{2}$. These infinite layers are composed of edge-sharing octahedral units with $\mathrm{O}-\mathrm{H}$ groups being perpendicular to the plane of the layers ${ }^{[2]}$. In the structure of hydrotalcite, some of the $\mathrm{Mg}^{2+}$ ions in the sheets are isomorphously substituted with $\mathrm{Al}^{3+}$ giving the layers excess positive charge, which is compensated by charge compensating anions $\left(\mathrm{A}^{\mathrm{n}}-\right)$ situated in the interlamellar space. A three-dimensional structure is generated by the stacking of the host layers on top of the other. In general, it may be stated that LDHs are composed of brucite-like layers, in which divalent cations are isomorphously substituted by trivalent cations giving the aforementioned positively charged layers. Between the layers charge compensating anions are situated. The general formula of these

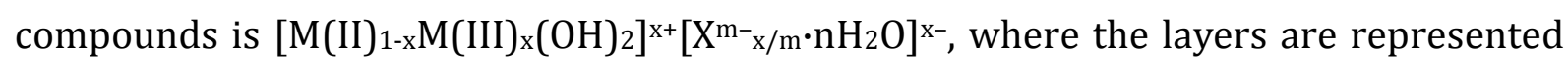
by $\left[\mathrm{M}(\mathrm{II})_{1-\mathrm{x}} \mathrm{M}(\mathrm{III})_{\mathrm{x}}(\mathrm{OH})_{2}\right]^{\mathrm{x}+}$ and the interlayer composition is $\left[\mathrm{X}^{\mathrm{m}-} \mathrm{x} / \mathrm{m} \cdot \mathrm{nH}_{2} \mathrm{O}\right]^{\mathrm{x}-[3]}$. The schematic structure of a layered double hydroxide is presented in Figure 1. A large variety of metals can be used as divalent and trivalent cations as constituents of the LDHs. The most common divalent cations are: $\mathrm{Mg}^{2+}, \mathrm{Ca}^{2+}, \mathrm{Mn}^{2+}, \mathrm{Cu}^{2+}, \mathrm{Co}^{2+}, \mathrm{Zn}^{2+}$, etc. The trivalent ones are $\mathrm{Al}^{3+}, \mathrm{Fe}^{3+}, \mathrm{Mo}^{3+}, \mathrm{Cr}^{3+}$, etc., while the most common charge compensating anions are $\mathrm{CO}_{3}{ }^{2-}, \mathrm{NO}_{3}{ }^{-}$and $\mathrm{Cl}^{-}{ }^{-4]}$. A general law for the formation of the LDH is that the ionic radii of the di- and trivalent cations should be in the same range[5], although some exceptions are known, e.g. in $\mathrm{Ba}(\mathrm{II}) \mathrm{Fe}(\mathrm{III})-\mathrm{LDH}$ the ionic radius of the $\mathrm{Ba}^{2+}$ is $1.49 \AA$, while that of $\mathrm{Fe}^{3+}$ is $0.79 \AA$ [6]. Although the majority of the LDHs are composed of di- and trivalent cations, there are documented cases, where instead of the trivalent metal ion, tetravalent metal ions were used, such as $\mathrm{Zr}^{4+[7]}$ and $\mathrm{Sn}^{4+}{ }^{[8]}$. A rare 
case is when monovalent cations and trivalent cations are used in forming the LDH. This is LiAl-LDH[9].

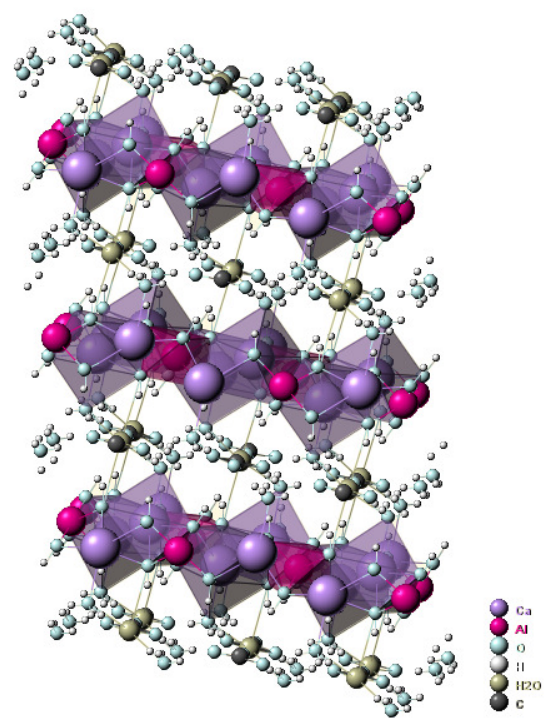

Figure 1. The schematic structure of a layered double hydroxide

It has been concluded that in order to obtain pure LDH phases the stoichiometry should be in the range of $0.2<\mathrm{x}<0.33$, which corresponds to a $\mathrm{M}(\mathrm{II}) / \mathrm{M}$ (III) molar ratios in the range of $2-4[10]$. When $x>0.33$ the energetically unfavorable $\mathrm{M}(\mathrm{III})-\mathrm{OH}-\mathrm{M}(\mathrm{III})$ linkage is unavoidable[11]. The energetically unfavorable state is due to the electrostatic repulsion between the neighboring trivalent metals in the layers as well as to the repulsion between the charge-compensating anions between the layers.

\subsection{Structure of the LDHs}

\subsubsection{Structure of the layers}

The layered structure of the LDHs is based on the structure of brucite, which is of the $\mathrm{CdI}_{2}$-type, typically associated with small polarizing cations and large polarizable anions. In it, the $\mathrm{Mg}^{2+}$ ions are surrounded by hydroxide ions in an approximately octahedral arrangement. These octahedral units form infinite layers. The layers are stacked on top of one another to form the three-dimensional structure. The structure is composed of close-packed planes of hydroxyl anions lying on a triangular lattice, while the metal cations occupy the octahedral holes between the alternate pairs of $\mathrm{OH}$ planes ${ }^{[12]}$. Both the local geometry around the metal and the close-packed hydroxyl anions are strongly distorted, the octahedra are compressed along the stacking axis, thus the local geometry at the metal is $\mathrm{D}_{3 d}$, rather than $\mathrm{O}_{h}$. The effects of this geometrical 
change are the increase in the $\mathrm{O}-\mathrm{O}$ and $\mathrm{Mg}-\mathrm{Mg}$ distance parallel to the plane, the decrease in the thickness of the layers and a change in the angle of the $0-\mathrm{Mg}-\mathrm{O}$ bond from the regular $90^{\circ}$ to $96.7^{\circ}$ and $83.3^{\circ}[13]$.

The LDHs, with structure derived from brucite, have similar geometry. The octahedra are strongly flattened along the stacking direction, lowering the symmetry from $\mathrm{O}_{h}$ to $\mathrm{D}_{3 d}$. The higher the ionic radius, the more flattened the octahedra are, resulting in the lowering in the thickness of the layers (h) and increasing the distance between the metals (Figure 2)[14].

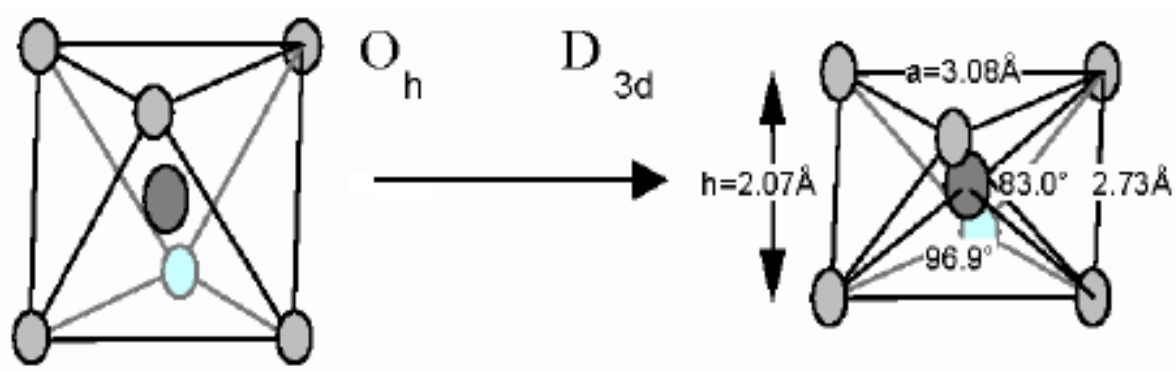

Figure 2. Deformation of the $\mathrm{M}(\mathrm{OH})_{6}$ octahedron in the $\mathrm{ZnAl}-\mathrm{LDH}$

The octahedral coordination of the metals in the layers could be lost, if the radius of the cations becomes too large. This can occur by the opening of one side of the octahedron on the interlamellar domain leading to additional coordination of one interlamellar water molecule. This way, the symmetry around the metal is lowered from $\mathrm{D}_{3 \mathrm{~d}}$ to $\mathrm{C}_{3 \mathrm{v}}$. This behavior is observed in minerals with $\mathrm{Ca}^{2+}$ as the divalent cation. For layers based on $\mathrm{Ca}^{2+}$ and $\mathrm{Al}^{3+}$, three different short- range distances are observed around $\mathrm{Ca}^{2+}: 3 \mathrm{Ca}-\mathrm{OH}$ at $2.375 \AA$, $3 \mathrm{Ca}-\mathrm{OH}$ at $2.455 \AA$ and $1 \mathrm{Ca}-\mathrm{OH} 2$ at $2.497 \AA^{[14]}$. The LDH structure is based on the corrugated main layers, with the ordered arrangement of $\mathrm{Ca}^{2+}$ and $\mathrm{M}^{3+}$ ions, having sevenfold and sixfold coordination, respectively, with the seventh apex of the Ca-polyhedron being the interlayer water molecule [15].

Minerals consisting of layers with pseudohexagonal symmetry usually exhibit different stacking sequences, yielding different polytypes. Different polytypes have equal number of layers per unit cell, but substantially differ from each other in layer arrangements. The stacking of the brucite-like layers in the LDHs can occur in many different ways, resulting in a variety of different possible polytypes.

The LDH polytypes can be classified by the number of stacked layers along the $c$ axis per unit cell, which can be 1, 2, 3 and 6 . When constructing the layered structure, in the stacking of the layers the opposing $\mathrm{OH}$ groups can lie either vertically above one 
another, in this case a prism-shaped interlayer arrangement is generated (P-type interlayers), or the $\mathrm{OH}$ groups are offset from this position, and octahedral arrangement is formed (0-type interlayers) [16]. From the combination of these layers three possible two-layered polytypes can be generated: $2 \mathrm{H}_{1}, 2 \mathrm{H}_{2}, 2 \mathrm{H}_{3}$. In the nomenclature of the polytypes, the first digit stands for the number of layers, the letter references the symmetry ( $\mathrm{H}$ for hexagonal, $\mathrm{R}$ for rombohedral), while the numerical subscript differentiates the particular polytypes. In polytype $2 \mathrm{H}_{1}$ both interlayers are of the Ptype, in $2 \mathrm{H}_{2}$ both interlayers are of the 0 -type, while $2 \mathrm{H}_{3}$ consists of the two types of interlayers in an alternating way. For the three layered polytypes there are nine different variations, from which seven have hexagonal $\left(3 \mathrm{H}_{1}, 3 \mathrm{H}_{2}, 3 \mathrm{H}_{3}, 3 \mathrm{H}_{4}, 3 \mathrm{H}_{5}, 3 \mathrm{H}_{6}\right.$, $\left.3 \mathrm{H}_{7}\right)$, and two have rombohedral symmetry $\left(3 \mathrm{R}_{1}\right.$ and $\left.3 \mathrm{R}_{2}\right)$. The $3 \mathrm{R}_{1}$ polytype only has $\mathrm{P}$ type interlayers; there are three, which are only composed of 0-type interlayers $(3 \mathrm{R} 2$, $3 \mathrm{H}_{1}$ and $3 \mathrm{H}_{2}$ ), while the rest of the three-layered polytypes have both $\mathrm{P}$ - and 0 -type interlayers. For the six-layered polytypes, the number of variations is quite large, with both rombohedral, and hexagonal symmetry. The polytype, in which a certain LDH crystallizes, is influenced not only by the cations within the layer, but by the interlayer anion as well. Studies show that the $\mathrm{CO}_{3}{ }^{2-}$ anions are positioned in the interlayer space, in a way that their oxygens can form hydrogen bonds with the $\mathrm{OH}$-groups of the brucitelike layers. This can only be realized with P-interlayers, where the oxygen atoms of the $\mathrm{CO}_{3}{ }^{2-}$ anion are positioned at equal distance from the $\mathrm{OH}$ sheets of the $\mathrm{LDH}[17]$. There are only two polytypes out of two- and three-layered variants with only P-type interlayers, the $2 \mathrm{H}_{1}$ and $3 \mathrm{R}_{1}$ polytypes; therefore, in the LDHs having this anion as charge compensating anion only these two polytypes are possible. Anions having 2D triangle arrangements (e.g. $\mathrm{NO}_{3}^{-}$), halogen anion and hydroxyls have similar behavior resulting in the same polytypes. However, if the anion is a tetrahedral (e.g. $\mathrm{SO}_{4}^{-}$or $\mathrm{CrO}_{4}^{2-}$ ) the diversity of the polytypes increases dramatically. The basal oxygens of the $\mathrm{SO}_{4}^{-}$and the $\mathrm{CrO}_{4}{ }^{2-}$ tetrahedra only form hydrogen bonds with hydroxyls of either the upper or the lower interlayer surface. If the position of the tetrahedral base is rigid enough in relation with the layered hydroxide sheets, the apical oxygens can bond with the hydroxyls from the upper sheet of this interlayer through water molecules. This allows the next brucitelike layer to have different position relative to the apical oxygens of the tetrahedra and the first layer. The result is that the minerals containing these anions can form structures with both P- and O-types of interlayers. Since the reflections of the X-ray 
diffraction (XRD) patterns are sensitive to the interlayer anion, it is difficult to distinguish between the various polytypes.

For synthetic monoanionic $\mathrm{Ca}^{2+} / \mathrm{M}^{3+} \mathrm{LDHs}$ several rombohedral space groups (R-3, $\mathrm{R}-3 \mathrm{c}, \mathrm{P}-3 \mathrm{c} 1)$, a monoclinic (C2/c) and two triclinic space groups (P1, P-1) have been observed. In the R-3 and R-3c space groups, the water molecules linked with the Ca atom are arranged in a straight line passing through the $\mathrm{Ca}^{2+}$ ions and they are perpendicular to the (001) plane. The neighboring brucite-like layers may be stacked in two different ways. In the first, $\mathrm{OH}$ groups form a prism resulting in a three-layered polytype with Ptype interlayers (3R), having R-3 unit cell. In the second, the $\mathrm{OH}$ groups form octahedron resulting in a six-layered polytype (6R) with 0-type interlayer having $\mathrm{R}-3 \mathrm{c}$ unit cell. This change in the unit cell depends largely on the size of the anion[18]. The chloride compounds crystallize in the R-3c space group, large anions like $\mathrm{I}^{-}$or $\mathrm{SO}_{4}{ }^{2-}$ favor the $\mathrm{R}-3$ unit cell, while intermediate ions like $\mathrm{Br}^{-}$exhibit both unit cells.

The replacement of $\mathrm{Al}^{3+}$ cations by larger trivalent metal ions results in a linear variation of the unit cell parameters, with the increase of the $\mathrm{M}^{3+}-\mathrm{OH}$ bond lengths the cell parameter $a$ increases while cell parameter $c$ decreases. In the octahedral layers the accommodation of the longer $\mathrm{M}^{3+}-\mathrm{OH}$ distances proceeds by flattening the $\mathrm{M}^{3+}(\mathrm{OH})_{6}$ octahedra along the $c$ axis in order to minimize the repulsion between the cations, just as for the hydrotalcite-like compounds[19]. The overall effect on these octahedral layers is a compression in the $c$ direction and an elongation in the $(a, b)$ plane.

\subsubsection{Interlayer anions}

The interlamellar domain in the LDHs can contain various anions, water molecules and sometimes other neutral or charged entities. There is almost no limitation to the nature of anions in the LDHs, as long as the anions do not abstract the metal ions from the hydroxide layers, and have a sufficient charge density in one cross section, not much less than $3.0 e / \mathrm{nm}^{2[20]}$. A major characteristic of the LDHs is that only weak bonding occurs between these interlamellar ions/molecules and the host structure, the layers of the LDH. Therefore, a great variety of anionic species can be located between the layers during the formation of the lamellar structure, or introduced by further anion exchange. These anions can be grouped in the following families of compounds:

- halides $\left(\mathrm{F}^{-}, \mathrm{Cl}^{-}, \mathrm{Br}^{-}, \mathrm{I}^{-}\right)$ 
- non-metal oxoanions $\left(\mathrm{BO}_{3}{ }^{3-}, \mathrm{CO}_{3}{ }^{2-}, \mathrm{NO}_{3}{ }^{-}, \mathrm{Si}_{2} \mathrm{O}_{5}{ }^{2-}, \mathrm{HPO}_{4}{ }^{2-}, \mathrm{SO}_{4}{ }^{2-}, \mathrm{ClO}_{4}{ }^{-}, \mathrm{AsO}_{4}{ }^{3-}\right.$, etc.)

- oxo- and polyoxometallate anions $\left(\mathrm{VO}_{4}^{3-}, \mathrm{CrO}_{4}^{2-}, \mathrm{MnO}_{4}^{-}, \mathrm{V}_{10} \mathrm{O}_{28^{6-}}, \mathrm{Cr}_{2} \mathrm{O}_{7}{ }^{2-}\right.$, $\mathrm{Mo}_{7} \mathrm{O}_{24}{ }^{6-}$, etc.)

- anionic complexes of transition metals $\left(\mathrm{Fe}(\mathrm{CN}) 6^{2-}\right.$, etc. $)$

- organic anions $\left(\mathrm{CH}_{3} \mathrm{COO}^{-}, \mathrm{C}_{6} \mathrm{H}_{5} \mathrm{COO}^{-}, \mathrm{C}_{12} \mathrm{H}_{25} \mathrm{COO}^{-}, \mathrm{C}_{2} \mathrm{O}_{4}{ }^{2-}, \mathrm{C}_{6} \mathrm{H}_{5} \mathrm{SO}_{3}{ }^{-}\right.$, etc. $)$

- anionic polymers (PSS, PVS, polyacrylate, etc.)

- biochemical anions. (various amino acids in anionic form, DNA with 500-1000 base pairs, ATP, ADP, etc.)

Given the fact that the stacked layers are kept together with weak bonds, depending on the charge and layout of the interlayer species, the basal spacing of the layers can be altered dramatically. The structure of the interlayer domain is more difficult to characterize than the main layers, since the different anions favor different type of interlayer structure, as was presented above. The X-ray diffractograms exhibit a regular stacking of the layers, from LDHs containing small anionic species (such as halides and carbonates) up to sulfate-containing LDHs having a basal spacing of $1.1 \mathrm{~nm}$. Depending on the size of the anion, the interlayer distances of the LDHs vary on a wide scale (Figure 3).

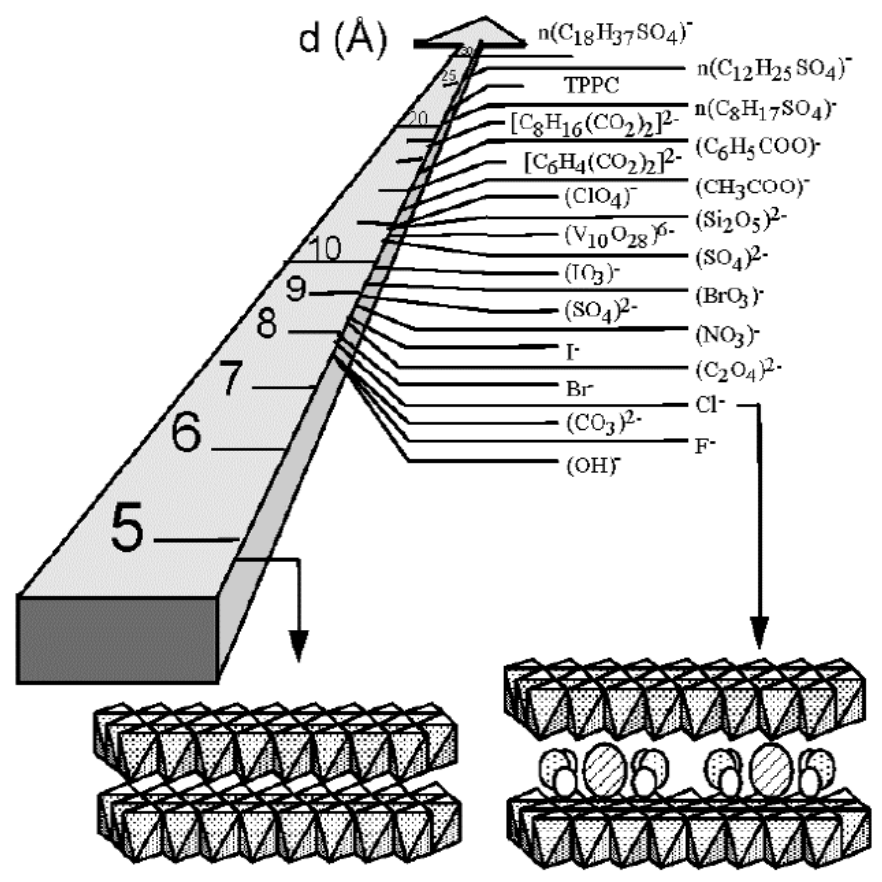

brucite $\mathrm{Mg}(\mathrm{OH})_{2}$

$[\mathrm{Mg}-\mathrm{Al}-\mathrm{Cl}] \mathrm{LDH}$

Figure 3. Evolution of basal spacing with intercalated anions 
For bulky anions, in most cases no long-range ordering is seen by the stacking of the layers any more (turbostratic effect), thus the diffractograms only show lines related to the basal spacing and the structure of the main layers.

The increase in the interlayer spacing can be monitored well by using XRD measurements, and it is usually referred to as d003, although this label is only valid for 3R stackings. Similar to the enlargement of the interlayer space, the gallery height can also be measured, which is the $\mathrm{d}_{003}$ basal spacing minus the thickness of the brucite-like layers.

The orientation of the anions takes place in a way that maximizes their interaction with the positively charged hydroxide layers. The $\mathrm{CO}_{3}{ }^{2-}$ anions are usually positioned parallel to the brucite-like layers, thus the three oxygen atoms can interact well with the hydroxide groups within the layers, forming hydrogen bonds. This orientation is also favorable, because it maximizes the electrostatic interaction between the carbonate anion and the positively charged layers[20]. This orientation is only changed when the trivalent cation content is increased to $\mathrm{x}=0.44$, in this case the orientation is changed from flat lying $\left(\mathrm{D}_{3 \mathrm{~h}}\right)$ to tilted $\left(\mathrm{C}_{2 \mathrm{v}}\right)^{[21]}$. For the nitrate anions, although they have the same shape as the carbonate anion, the lower charge density leads to deviation from the flatlying structure to an alternating upper-lower gallery surface model[22]. For tetrahedral anions, such as $\mathrm{SO}_{4}^{2-}, \mathrm{MoO}_{4}^{2-}, \mathrm{CrO}_{4}{ }^{2-}, \mathrm{PO}_{4}^{3-}, \mathrm{ClO}_{4}^{-}, \mathrm{CoCl}_{4}{ }^{2-}$ and $\mathrm{NiCl}_{4}^{2-}$, there are two possible ideal configurations. The pyramidal configuration has three oxygen/chlorine atoms closer to hydroxyl groups in one layer and the forth opening toward the opposite hydroxyl plane. In this case the $C_{3}$ axis is perpendicular with the hydroxide plane. The other configuration places two oxygen atoms toward the opposite hydroxyl planes of each of two adjacent brucite-like layers, giving rise to a smaller height ${ }^{[23]}$.

The orientations of organic anions are related to the anion concentration and the reaction temperature used in the synthesis. For aliphatic monocarboxylates and sulfonates, there are three possible cases: monolayer (strictly speaking, interpenetrating bilayer), simple bilayer, and partial overlap packing. Normally the carboxylate group is anchored to the brucite-like layers, while the hydrocarbon chain is slanted at an angle. The ideal angle is $55^{\circ}$, since the two oxygen atoms in the carboxylate group can interact equally with the hydroxide groups of the layer. The hydrocarbon chains are fully extended in the energetically favorable all-trans conformation with strong mutual hydrophobic interactions ${ }^{[24]}$. Organic anions always interact via their anionic groups 
being strongly hydrogen bonded to the surface hydroxyl groups, while their hydrophobic hydrocarbon chains are pushed far away from the hydrophilic layer surface, and adopt the lowest energy conformation ${ }^{[25] .}$

\subsection{Aluminum-, iron- and tin-based layered double hydroxides}

The main fundamental characteristic feature to distinguish between different naturally found or synthesized LDHs is their chemical composition. A large variety of divalent and trivalent cations can take part in the forming of these compounds. The ones found in nature as minerals, are the following: $\operatorname{Mg}(\mathrm{II}) \mathrm{Al}(\mathrm{III})$ (hydrotalcite-manasseite), $\mathrm{Mg}(\mathrm{II}) \mathrm{Fe}(\mathrm{III})$ (pyroaurite-sjögrenite), Ni(II)Fe(III) (honessite-reevesite), Ni(II)Al(III) (takovite), $\mathrm{Cu}(\mathrm{II}) \mathrm{Al}(\mathrm{III}) \quad$ (woodwardite), $\mathrm{Mg}(\mathrm{II}) \mathrm{Cr}(\mathrm{III}) \quad$ (stichtite), $\mathrm{Ca}(\mathrm{II}) \mathrm{Al}(\mathrm{III})$ (hydrocalumite) etc. There is a particular type of LDH called green rust, which contains Fe as both divalent and trivalent cations. Apart from these naturally occurring LDHs an even larger variety of these compounds can be synthesized. The most frequently used synthesis technique is the co-precipitation method, in which a combination of $\mathrm{M}^{2+}-\mathrm{M}^{3+}$ metal salts under alkaline conditions yields the desired LDHs. The vast majority of the published papers considers Al-containing LDHs, particularly MgAl-LDHs ${ }^{[23] ~[26] ~[27] ~[28] . ~}$ This is partly due to the fact that hydrotalcite is a widely known anionic clay found in nature, basically, it is the most significant mineral in the group. In addition, the amphoteric feature of $\mathrm{Al}^{3+}$ plays a favorable role in promoting the precipitation and crystallization of the LDH.

LDHs containing $\mathrm{Ca}(\mathrm{II})$ and $\mathrm{Al}(\mathrm{III})$ can be found in nature as a mineral called hydrocalumite[29], and can also be synthesized [30]. Its structure is similar to that of the hydrotalcite; however, the coordination around the $\mathrm{Ca}$ (II) changes to sevenfold from the octahedral one of $\mathrm{Mg}(\mathrm{II})$, being significantly larger than this latter ion. Hydrocalumites (various forms exist) have industrial role as well, because they are important intermediates in the Bayer process [31] [32]. The structure of these materials was studied and characterized thoroughly in the literature [15], and was presented above when the structure of the layers was discussed.

LDHs containing Fe(III) can be found in nature as minerals called pyroaurite ${ }^{[33]}$ and iowaite ${ }^{33]}$. Basically the pyroaurite is $\mathrm{Mg}(\mathrm{II}) \mathrm{Fe}(\mathrm{III})-\mathrm{LDH}$ with $\mathrm{CO}_{3}{ }^{2-}$ as chargecompensating anion, while in the iowaite it is the $\mathrm{Cl}^{-}$ions. $\mathrm{Ca}(\mathrm{II}) \mathrm{Fe}(\mathrm{III})$-LDHs cannot be found in the nature, but they can be synthesized [34] [35]. The main synthetic procedures are the co-precipitation and urea hydrolysis methods. Iron-containing LDHs have many 
potential application fields due to the characteristics of iron. One of these characteristics is the variable valence of iron; utilizing this feature, iron-containing LDHs are of importance in catalysis[36]. Another advantage of iron-containing layered double hydroxides the possibility to convert them into magnetic materials, which could lead to some non-conventional applications.

While LDHs having different di- and trivalent cations are quite common in the literature, the partial or full replacement of the M(III) ions for M(IV) ones is an entirely different matter. The first mention of M(IV)-containing LDHs was as early as 1997 [37]. The authors reported the successful synthesis of $\operatorname{Mg}(\mathrm{II}) \mathrm{Al}(\mathrm{III}) \operatorname{Zr}(\mathrm{IV})$-LDH. Soon after that, they have published a paper, in which they claimed the success of the preparation of $\mathrm{Mg}(\mathrm{II}) \mathrm{Al}(\mathrm{III}) \mathrm{Sn}$ (IV)-LDH using the simple co-precipitation method[38]. The claim was based on the changes in the lattice parameters due to the presumed incorporation of Sn(IV), obtained from the X-ray diffraction patterns. They also suggested a mechanism for the incorporation of Sn(IV). The theory was that some of the trivalent cations in the LDH layer were substituted by the tetravalent cations. After this, the syntheses of other similar systems (NiAlSn, CoAlSn) were also reported by this group [39] [40]. Soon after that, another group [41] [42] embarked on studying this topic again, and attempted the synthesis of $\mathrm{Mg}(\mathrm{II}) \mathrm{Al}(\mathrm{III}) \mathrm{Sn}(\mathrm{IV})-\mathrm{LDH}$ with the method given earlier [38] and for characterization, ${ }^{119} \mathrm{Sn}$ Mössbauer and X-ray absorption spectroscopies were applied. It was found that the tetravalent cations were not incorporated in the layers of the LDH, instead, they formed M(IV) oxide-like particles, which were segregated from the layers.

After these findings were published, the scientific community with an interest in M(IV)-type LDHs, has been divided into two main groups. Some years later, the first one continued to study M(II)M(III)M(IV) systems [43] [44]. They also found that the Sn(IV) ions were not incorporated in the layers; nevertheless, the segregated Sn(IV) oxide-like particles improved the catalytic properties of these materials. The other one tried a different, and in a way safer approach, and attempted to prepare M(II)Sn(IV)-LDHs [45] [46]. It is safer, since there is no added M(III), thus there is no competition with the usually more favored M(II)M(III)-LDH formation. Just like in the other cases, solutionphase chemical method (hydrolysis with urea) was applied and success in the syntheses of Co(II)Sn(IV)-LDH samples was reported.

The rarity and controversy surrounding these LDHs is not the only reason, why they are intriguing. LDHs containing Sn(IV), could have several applications: they can act 
as catalysts in Baeyer-Villiger reactions [47], in which the presence of $\mathrm{Sn}(\mathrm{IV})$ is crucial, or also as catalyst in liquid-phase methanol carbonylation[48], or as an additive for the stabilization of PVC[49].

\subsection{Preparation and intercalation methods}

LDHs are inexpensive and simple materials to synthesize both in laboratory and on the industrial scale. Several methods are known for the synthesis of these materials; they are not only for the preparation of these compounds, but for their modifications to suit the specific requirements of the field of applications.

\subsubsection{The co-precipitation method}

Co-precipitation is the most frequently applied method for the synthesis of LDHs. This is based on the slow addition of the solution of di- and trivalent metal salts into a second, vigorously stirred alkaline solution, with the relative rates of the addition regulated the way that the overall $\mathrm{pH}$ remained steady. At this selected $\mathrm{pH}$ value the coprecipitation of the two metallic salts takes place, thus forming the LDH. It should, however, be noted that precipitation will be occurring in the mixing region around the metal salt inlet, where the $\mathrm{pH}$ will be far from constant, and precipitation of the most insoluble metal hydroxide will be rapid. The final precipitate will be formed at the nominal reaction $\mathrm{pH}$ if at least one of two conditions is satisfied: the rate of mixing is larger than the rate of conversion of the initial precipitate to $\mathrm{LDH}$, or the mixture is left stirring long enough for any LDH formed in the mixing zone to redissolve as part of a process of Ostwald ripening. The $\mathrm{pH}$ chosen must evidently be higher than that necessary for LDH formation, but it should also be lower than that required for precipitation of the divalent metal hydroxide itself or its basic salts ${ }^{[20]}$.

The mechanism of co-precipitation is ideally based on the condensation of hexaaqua complexes in solution, leading to the build-up of the brucite-like layers having both metallic cations evenly distributed, and solvated interlayer anions. The XRD characterization of the precipitates shows that the co-formation of the main layers and interlayer domains takes place at a very early stage of the process without clear "delaminated" state of the layers[14]. During this procedure the charge-compensating anions could come from various sources. They can originate from the solution of the divalent and trivalent metal salts. In this case, these anions are the counter ions of these 
metals. If the preparation is performed at very high $\mathrm{pH}$ values, the interlayer anion can be the $\mathrm{OH}^{-}$anion coming from the alkaline solution. If alkaline conditions are maintained via using sodium or potassium carbonate, the intercalated anion becomes the carbonate anion due to its high selectivity for the LDHs interlayer domain. When the preparation is performed at relatively high $\mathrm{pH}$ values, the $\mathrm{CO}_{2}$-free conditions are imperative to avoid carbonate contamination. The experimental device for the described synthesis method is presented in Figure 4.

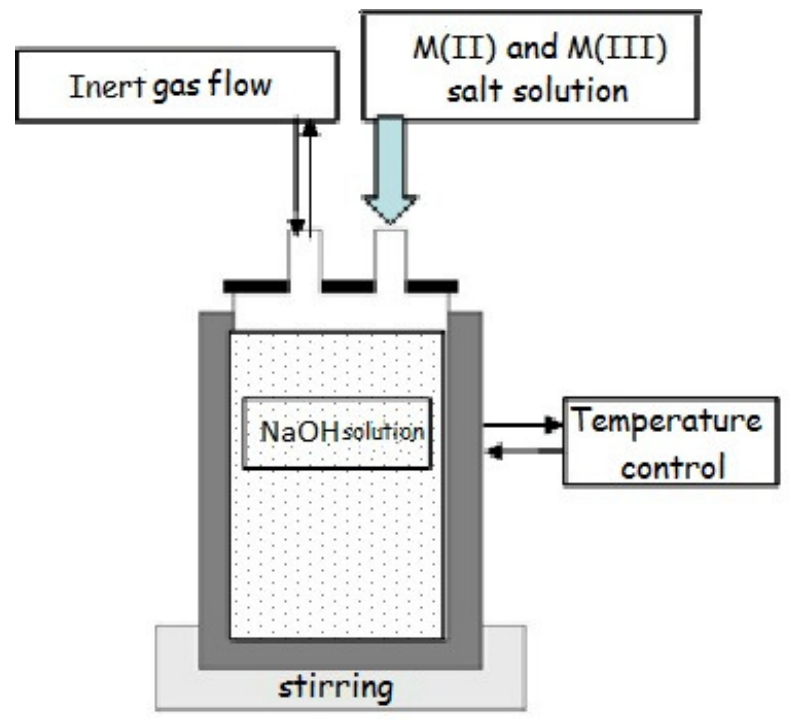

Figure 4. The schematic presentation of the experimental setup for the synthesis of LDHs using the coprecipitation method

If the desired intercalated anion is different from the counter ions of the metals in the precursors, a solution of this anion is prepared and introduced to the reactor prior to the beginning of the co-precipitation. If this route is selected for intercalation a $\mathrm{CO}_{2}$-free environment needs to be maintained, and the liotropic series of the anions needs to be taken into consideration (described in detail when the direct anion change is discussed). This synthetic route is often chosen as the method for preparing LDHs containing organic anions, which are difficult to synthesize in any other way.

The reaction conditions of this procedure have profound effect on the product, it is possible to obtain well-crystallized LDH phases or quasi amorphous materials. The influencing experimental parameters can be more and less obvious. The more obvious parameters are:

- the temperature in the reactor

- $\mathrm{pH}$ of the reaction

- concentration of metal salt solutions 
- concentration of the alkaline solution

- flow rate of the reactants

- ageing of the precipitate

Other not so obvious parameters are:

- accumulation of electrolytes in the reaction medium

- hydrodynamics of the dilution of reactive species, related to the stirring mechanism

- geometry of the reactor including reactants injection pipes

- complexation state of the metal cations ${ }^{[14]}$

The co-precipitation method has two commonly employed types: precipitation at constant $\mathrm{pH}$ value, and precipitation at variable $\mathrm{pH}$. To get well-defined phases with good crystallinity, the procedures need to be optimized taking into consideration the above mentioned parameters.

In order to increase the yield and/or the crystallinity of the amorphous or poorly crystallized materials, (hydro)thermal treatment often follows the co-precipitation. In most cases, the hydrothermal treatment in the presence of water vapor strongly improves the crystallinity of the LDH, provided the temperature of decomposition of the LDH is not exceeded. The ageing procedure is performed through heating the LDH suspension at a temperature in the range of $0-100^{\circ} \mathrm{C}$ for several hours or even days.

\subsubsection{The urea hydrolysis method}

This preparation method has the same principle as the co-precipitation method, with the difference that the urea solution provides the desired $\mathrm{pH}$ value. Urea has a series of properties that makes its use as an agent for precipitation from "homogeneous" solution very attractive and it has long been used in gravimetric analysis to precipitate several metal ions as hydroxides or as insoluble salts in the presence of a suitable anion[50]. Urea is a very weak Brønsted base $\left(\mathrm{pK}_{\mathrm{b}}=13.8\right)$, highly soluble in water, and its hydrolysis rate may be easily regulated by controlling the temperature of the reaction. The mechanism of hydrolysis consists of the formation of ammonium cyanate, as the rate-determining step, and the fast hydrolysis of the cyanate to ammonium carbonate ${ }^{[51]}$ (Equations (1) and (2)).

$$
\begin{gathered}
\mathrm{CO}\left(\mathrm{NH}_{2}\right)_{2} \rightarrow \mathrm{NH}_{4} \mathrm{CON} \\
\mathrm{NH}_{4} \mathrm{CNO}+2 \mathrm{H}_{2} \mathrm{O} \rightarrow\left(\mathrm{NH}_{4}\right)_{2} \mathrm{CO}_{3}
\end{gathered}
$$


Increasing the temperature from 60 to $100^{\circ} \mathrm{C}$, the rate of the hydrolysis increases about 200 times. The hydrolysis of ammonium to ammonia and carbonate to hydrogen carbonate gives a $\mathrm{pH}$ value of about 9, depending on the temperature. This $\mathrm{pH}$ is suitable for precipitating many metal hydroxides and a variety of LDHs. The urea hydrolysis method is suitable for the preparation of MgAl-LDHs with high layer charge densities ${ }^{[52]}$. The LDH prepared by this method produces crystallites with relatively large size (microns in diameter) and a well-defined hexagonal shape due to low supersaturation during precipitation[53]. The particle size can be controlled by the rate of the hydrolysis, i.e., the temperature; large particles are formed at lower temperatures due to the lower nucleation rate[54]. The main disadvantage of this method is that the LDHs synthesized usually contain carbonate as charge-compensating anion, and this anion cannot be replaced by other anions during the intercalation processes. Another disadvantage is that LDHs formed from metal ions, which precipitate at higher $\mathrm{pH}$, cannot be obtained via urea hydrolysis method.

\subsubsection{Direct anion-exchange method}

This method is different from the above mentioned methods, because direct anionexchange is not a synthesis, but an intercalation method. As it was described for coprecipitation, various, even large organic anions can be introduced among the layers of the LDHs. On using the direct anion exchange, the goal is to introduce the chosen anion between the layers of an already formed LDH, exploiting the exchange properties of the interlayer anions ${ }^{[5]}$. This intercalation method is useful when the co-precipitation method is inapplicable, like when one of the metal cations, or the anion is unstable under alkaline conditions, or the direct reaction between metal ions and guest anions is more favorable, or the desired guest anion could not be prepared as a metal salt. Anion exchange from thermodynamic point of view depends mainly on the electrostatic interactions between the host sheets and the exchanging anions, hydrogen bonding, and on the free energy associated with the change of hydration[56]. The equilibrium constant increases when the ionic radius of the bare anion decreases, therefore, the exchange is favored for incoming anions with high charge density. Miyata[57] gave a comparative list of ion selectivities for mono- and divalent anions (Equation(3)) from the calculated equilibrium constants:

$$
\mathrm{CO}_{3}{ }^{2-}>>\mathrm{C}_{10} \mathrm{H}_{4} \mathrm{~N}_{2} \mathrm{O}_{8} \mathrm{~S}^{2-}>\mathrm{SO}_{4}{ }^{2-}>>\mathrm{OH}^{-}>\mathrm{F}^{-}>\mathrm{Cl}^{-}>\mathrm{Br}^{-}>\mathrm{NO}_{3}^{-}>\mathrm{I}^{-}
$$


Yamaoka et al.[58] determined an equivalent selectivity sequence for divalent oxoanions (Equation (4)):

$$
\mathrm{HPO}_{4}{ }^{2-}, \mathrm{HAsO}_{4}{ }^{2-}>\mathrm{CrO}_{4}{ }^{2-}>\mathrm{SO}_{4}{ }^{2-}>\mathrm{MoO}_{4}{ }^{2-}
$$

From these results, it is clear that in order to successfully change a given anion to another, some aspects of the procedure need to be taken into consideration. The $\mathrm{CO}_{2}$ has to be excluded from the system, because the carbonate anion has the strongest bond with the layers, i.e., it is practically impossible to exchange this anion from the layers. A suitable good leaving anion needs to be selected as precursor, such as nitrate or chloride.

From a kinetic point of view, the rate-determining step of the reaction is the diffusion of the incoming anions within the layers, while the "infinite solution conditions" are respected. If the basal spacing of the precursors proves to be too small, this can prevent the diffusion of large anions into the interlayer space. In these cases, the intercalation is carried out via organic anion-pillared precursors. This is basically a twostep anion exchange, the first step being the exchange of the precursor anion to the organic anion-pillar, which increases the basal spacing, thus the interlayer distance; therefore the desired anion can enter the interlayer space. The favorability of the anionexchange is related to five main factors:

- The exchange ability of the incoming anions increases with the increase of the charge and the decrease of the ionic radius.

- The appropriate choice of the solvent will favor the swelling and the anion exchange of the precursor LDH[59].

- The $\mathrm{pH}$ of the anion exchange is important. It should be generally larger than 4 , in order to preserve the host LDH layers. Low $\mathrm{pH}$ value favors the incorporation of less basic anions, and the liberation of anions, which are weak conjugate acids ${ }^{[60]}$.

- The chemical composition of the host layers can affect the anion-exchange process.

- High temperatures favor the anion-exchange process.

\subsubsection{Dehydration-rehydration method}

This intercalation method exploits one of the key features of the LDHs, the memory effect. The memory effect is the ability of the LDH to reconstruct its structure by adding 
water to the collapsed structure of the calcined LDH. This phenomenon was first described by Miyata in 1980[61]. The intercalation of various anions using the memory effect takes place in two steps. The first step is the calcination of the LDH into a mixture of oxides, after which the LDH structure is regenerated by rehydrating the mixture of oxides with an aqueous solution of the soon-to-be-intercalated anion. Thus, after the LDH structure is regenerated, the charge compensating anions will be the anions of the aqueous solution, rather than the precursor LDHs charge compensating anions (Figure 5).
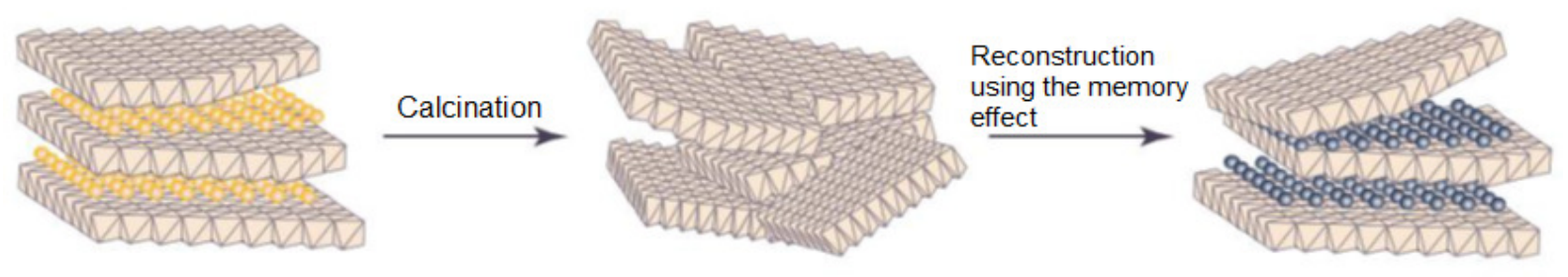

Figure 5. A schematic presentation of dehydration-rehydration

The conditions of the calcination, such as temperature ramp speed and the duration of the treatment, are important parameters determining the recovery of the structure. The series of calcination-structure reconstruction cannot be repeated endlessly, without consequences, there is a limit to the reversibility of the process. Repeated calcination/rehydration cycles of the hydrotalcite decreases the content of the interlayer carbonate anions, and increases the extraction of $\mathrm{Al}^{3+}$ from the brucite-like layers [62]. This method cannot be applied for every LDH type, the reconstruction of $\mathrm{Fe}^{3+}$ containing LDHs is limited by the formation of $\mathrm{MgFe}_{2} \mathrm{O}_{4}$ spinel, which appears even at low $\mathrm{Fe}^{3+}$ content. During the calcination process four large thermal events can be identified

- Between room temperature and $250^{\circ} \mathrm{C}$, a continued dehydration and dehydroxylation of the layers.

- Between 250 and $350^{\circ} \mathrm{C}$ the decomposition of the interlayer anion. During this phase there is notable increase in the activation energy values, indicating the existence of various, simultaneous processes.

- Between 350 and $550^{\circ} \mathrm{C}$ the shrinkage and the collapse of the layered structure.

- Above $550^{\circ} \mathrm{C}$ the crystallization of new phases ${ }^{[63]}$. 
The spinel formed at around $1000^{\circ} \mathrm{C}$ cannot be converted back to LDH through the memory effect. After dehydroxylation, quasi-amorphous mixed oxides are obtained, which crystallize progressively at higher temperatures, generally as $\mathrm{M}(\mathrm{II}) \mathrm{M}(\mathrm{III})_{2} \mathrm{O}_{4}$ spinel-like phases and the divalent metal oxide. The ill-organised mixed oxides display broad XRD diffraction peaks, which usually correspond to the strongest lines of the future spinel-like phase, therefore they are called pre-spinel oxides. The transformation from the LDH structure to these oxide phases can be topotactic. The surface area of these mixed oxides display a relatively high specific surface $\left(100-300 \mathrm{~m}^{2} / \mathrm{g}\right)$ compared to the LDHs $\left(\sim 15 \mathrm{~m}^{2} / \mathrm{g}\right)$. Due to these high specific surface mixed oxides are frequently used in heterogeneous catalysis.

The application of this method for intercalation purposes has some advantages compared to the direct anion change. Even large organic anions can be intercalated within the layers, the relatively small basal spacing of the layers is not a limiting factor, and there is no need for the application of pillaring anions. During the rehydration process inert (e.g., $\mathrm{N}_{2}$ ) atmosphere needs to be provided, in order to assure that the desired anion will be sited among the layers and not of the carbonate anion. It has also to be noted that it is difficult to obtain a pure crystalline product, because the lamellar structure of the LDHs can often only be partially restored during this process ${ }^{[64]}$. The extent of intercalation using this method depends on the reaction medium, the composition of the host layers, and the geometric and electronic structures of the anions. Applying the dehydration-rehydration method a wide range of anions, including amino acids, has been incorporated into the LDH structure.

The methods presented above are the main solution- phase preparation and intercalation methods. There are several different methods, which are used rarely and in particular cases, these are: hydrothermal synthesis[65], the sol-gel process[66], the SNAS method involving separate nucleation and aging steps ${ }^{[67]}$, the salt-oxide method ${ }^{[68]}$, the electrochemical synthesis ${ }^{[69]}$, the reverse microemulsion method ${ }^{[70]}$, etc.

\subsubsection{Mechanochemical method}

The methods described in the previous chapter are the most common and widely used solution-phase methods. Another technique, which can be used for both the preparation of LDHs and for intercalation purposes, is the mechanochemical method. The principle of this method is that the precursors under the conditions of the 
mechanical treatment undergo a chemical reaction resulting in the formation of the LDH. Given that the formation of the LDH takes place in the solid state, there is no need for filtration, which, in many cases proves to be quite difficult; there is no need for further treatments such as aging or hydrothermal treatment to increase the crystallinity of the LDH phases.

The first mechanochemical method was applied for the synthesis of hydrotalcites (MgAl-LDHs) by Khusnutdinov and Isupov, using a planetary ball mill[71]. The synthesis was carried out by milling the precursors $\left(\mathrm{Mg}(\mathrm{OH})_{2}\right.$ and $\left.\mathrm{AlCl}_{3}{ }^{6} 6 \mathrm{H}_{2} \mathrm{O}\right)$ in the planetary ball mill. The result was the synthesis of hydrotalcite with good crystallinity. On the basis of the obtained experimental data, a scheme was proposed for the mechanochemical interaction in the mixture. In the initial system, $\mathrm{OH}^{-}$ions are only presented as the hydroxide lattice of the brucite layers. Mechanochemical activation leads to the partial substitution of magnesium in brucite for aluminium. To conserve the zero charge, hydroxide and chloride ions were inserted into the interlayer space. Under the conditions of mechanical treatment, the interaction of $\mathrm{Al}(\mathrm{OH})_{3}$, and $\mathrm{Mg}(\mathrm{OH})_{2}$ occurred, resulting in the formation of hydrotalcite structure.

Later on, a two-step milling procedure was developed by Tongamp et al.[72], in which as precursors, the hydroxide forms of the di- and trivalent metals were used. The first step of this procedure was the dry milling of the precursors, followed by the addition of minute amount of water, after which the milling was resumed (wet-milling). The addition of this minute amount of water was imperative, because the hydroxide groups provided by the precursors did not prove to be enough for the LDH to form. During the dry milling step, the mechanochemical activation of the precursors took place (the mechanochemical activation will be described in detail when discussing mechanochemistry in chapter 2.4), while the small amount of solvent can be described as a sort "solvent catalysis" of the solid-state process, in which a small amount of solvent acts like a lubricant for molecular diffusion[73]. During this wet milling the actual formation of the LDH occurs. Later, Ay et al. ${ }^{[74]}$ suggested that the use of the ball mill is not even necessary, a simple agate mortar and manual grinding were claimed to be adequate to provide with the LDH. As precursors, the hydrated metal salts were applied; thus, the addition of further water was not necessary.

The mechanochemical method was successfully used for intercalation purposes as well. A technique used in the literature ${ }^{[75]}$ [76] is a "soft" mechanochemical treatment, 
using manual grinding, with mortar and pestle, which is similar to the direct anion exchange. An already synthesized $\mathrm{NO}_{3}{ }^{-}$containing $\mathrm{LDH}$ was used as precursor, to which the intended anion was added with a minute amount of $\mathrm{NaOH}$, and manually grinded. During the grinding procedure the $\mathrm{NO}_{3}^{-}$anions were exchanged for the desired molecules in anionic form. Conterosito et al. used two intercalation methods involving grinding with mills[77]. The first method is similar to the above-described method, when the already synthesized $\mathrm{NO}_{3}^{-}$containing $\mathrm{LDH}$ is milled with $\mathrm{NaOH}$, and the soon-to-beintercalated anion. The second method is a "one-pot" mechanochemical synthesis. In this case, the precursors of the LDH were mixed and milled together with the soon-to-beintercalated anion, and after a certain amount of time, $\mathrm{NaOH}$ was added to the system. During this method the formation and intercalation of the LDH take place simultaneously, in one step. There is no need to synthesize the LDH first, and then introducing the interlayer anion, the whole procedure takes place at once, that is why it is called "one-pot" mechanochemical synthesis.

The mechanical milling can be combined with heat treatment, giving birth to a mechano-hydrothermal method, which can be used as an intercalation as well as a preparation method[78]. In this two-step process, the first step is the milling of the LDH precursors (metal salts) in a planetary ball mill, followed by the addition of the solution of the soon-to-be-intercalated molecules solution to the mixture of the precursors. This was shaken thoroughly and heated in an oven under static conditions, the heating temperature is usually $120^{\circ} \mathrm{C}$. The mechanism of the $\mathrm{LDH}$ formation under these circumstances, as the procedure itself, has two major steps, the milling and the hydrothermal treatment ${ }^{[79]}$. During the milling steps the activation, the size reduction and the pre-mixing of the precursors take place resulting in the active sites, which are favorable for $\mathrm{LDH}$ formation. In the hydrothermal treatment, the necessary $\mathrm{pH}$ is provided for the LDH to form. It has been proved that the pre-milling step improved the chemical activity of the starting materials, resulting in a lower reaction temperature of the hydrothermal treatment, compared to the un-milled starting materials.

\subsection{Mechanochemistry}

"Mechanochemistry is a branch of chemistry, which is concerned with chemical and physico-chemical changes of substances of all states of aggregation due to the influence of mechanical energy." This definition is based on theoretical considerations of Ostwald concerning the relationship between chemical and mechanical energy. Despite 
the long history of mechanochemistry, the definition of a mechanochemical reaction was only recently incorporated into the chemical literature. The recent IUPAC Compendium of Chemical Terminology defines mechanochemical reaction as a "chemical reaction that is induced by mechanical energy".

Unintentional chemical reactions accompany many forms of mechanical action, like grinding, sliding, or plastic deformation, while the deliberate application of mechanical energy, typically by means of high-energy ball milling, provides a method to prepare useful new materials and to improve the efficiency of complex processes. The chemical effects of mechanical action are different from the effects of heat, and realizing, explaining, and utilizing this fact is an important thread in the history of mechanochemistry.

\subsubsection{The history of mechanochemistry}

Grinding can be regarded as the first engineering technology and its traditional instrument, the mortar and pestle, was already used in the Stone Age. As some grinding operations were surely accompanied by unintended chemical changes, there is a reason to claim that practical mechanochemistry has been with us for a very long time[80].

Theophrastus of Eresus, Aristotles' student and successor at the helm of the Lyceum, wrote a short booklet titled "On Stones" in about 315 B.C. This is the earliest surviving document related to chemistry. In it stands: "native cinnabar was rubbed with vinegar in a copper mortar with a copper pestle yielding the liquid metal". This a reference on the reduction of cinnabar to mercury by grinding in a copper mortar with a copper pestle[81] (Equation (5)).

$$
\mathrm{HgS}+\mathrm{Cu} \rightarrow \mathrm{Hg}+\mathrm{CuS}
$$

Although this process is clearly mechanochemical according to modern classification, its inclusion in the book of Theophrastus certainly does not suggest that ancient Greeks knowingly practiced mechanochemistry. Nevertheless, it demonstrates that the application of the mortar and pestle, and consequently the possibility of initiating chemical reactions by grinding, extended from grains to inorganic materials is rather early. For the next 2000 years nothing explicit is known regarding mechanochemistry, even though grinding and milling were extensively used in grain, mineral, pharmaceutical, building material, black gunpowder, etc. processing. The 
mortar and pestle also were standard instruments in the laboratory of the alchemists and the early chemists.

In an early paper published in 1820, Faraday described the reduction of silver chloride by grinding with zinc, tin, iron, and copper in a mortar ${ }^{[82]}$. He called this the "dry way" of inducing reactions, using the term very casually. His style suggests that the induction of a chemical reaction upon grinding was a familiar procedure for him, and most probably, it was also known to others. His choice of words supports the view that knowledge on mechanochemical reactions existed, even though there is little record of it in the literature.

The first mechanochemist was Carey Lea, an American scientist, who lived in the late $19^{\text {th }}$ century. His main work involved the study on colloidal silver, the halides of $\mathrm{Ag}$, $\mathrm{Hg}$, Pt and $\mathrm{Au}$. Lea has shown for the first time the parallelism between the action of electricity, heat, light, chemical action and mechanical force on silver halides and allotropic silver. He experimentally proved the theoretical ideas of Ostwald's, who in his textbooks on general chemistry understood the equivalency of electrochemistry, thermochemistry and photochemistry with mechanochemistry.

While Lea focused on single compounds another American chemist, Parker, studied solid-solid reactions [83]. He even proposed a sketch for the first mechanochemical reactor, which was basically a mortar with pestle fixed in a desiccator. Both Parker and Lea recognized the importance of controlling the atmosphere during the grinding process, which supports the necessity of the use of a desiccator in the building of the mechanochemical reactor. Mechanochemistry became an accepted separate branch of chemistry, when it first appeared in the classification of a textbook. This happened in 1919, when Ostwald included mechanochemistry in his chemical systematics, together with thermochemistry, electrochemistry, and photochemistry.

In the modern history of mechanochemistry the International Conference on Mechanochemistry and Mechanical Alloying (INCOME) series was initiated by the International Mechanochemistry Association IMA (an associate member of IUPAC) established in 1988.

\subsubsection{Mechanochemical tools}

The most important tool of practical mechanochemistry is the ball mill, thus progress in mechanochemistry is closely connected to new advances in grinding 
technology and mill design. The first mill used on a large scale was the tumbling mill, which had balls as milling bodies. It was the ancestor of the planetary ball mills used today. The amount of the transmitted energy could be regulated by the drop height of the milling bodies. The next step in the development of the mills was the invention of the stirred-ball attritor by Andrew Szegvari followed by the development of the first vibration mills. In a small tumbling mill, the dropping distance and therefore the energy of the impacts are low. But more energetic impacts can be achieved by putting the milling drum on a centrifuge in order to simulate a substantially larger acceleration of gravity. This is the idea behind the operation of the planetary mill, invented by the Fritsch company in 1961[80].

The planetary ball mills are the workhorses of many laboratories concerned with mechanochemistry, given that the settings can be varied in a way that a wide variety of milling parameters can be set. The energy density in these mills is 100-1000 times higher than the energy density used in earlier conventional milling equipment. For the mechanochemical processing of small samples, typically for laboratory use, shaker, disc and vibration mills are very suitable. Since then, the number of different types of mills for different types of reactions and applications skyrocketed (Figure 6).

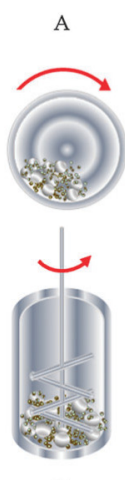

$\mathrm{D}$

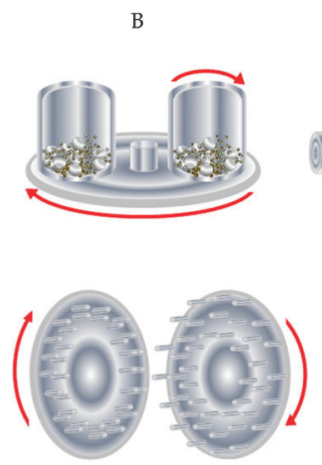

E

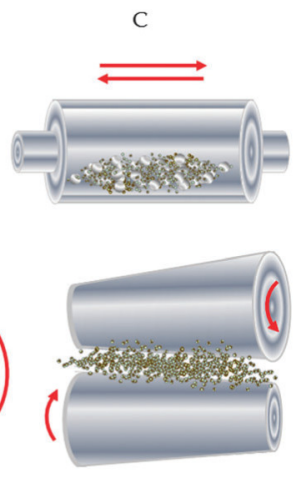

Figure 6. Different types of mills for high energy milling: A - ball mill, B - planetary ball mill, C - vibration mill, D - attritor (stirring ball mill), E - pin mill, $\mathrm{F}$ - rolling mill

Mechanochemical vials or reactors and balls are available from different materials such as agate $\left(\mathrm{SiO}_{2}\right)$, silicon nitride, sintered corundum, zirconia (tetragonal $\mathrm{ZrO}_{2}$ stabilized with $\mathrm{Y}_{2} \mathrm{O}_{3}$ ), chrome steel, $\mathrm{Cr}-\mathrm{Ni}$ steel, tungsten carbide, or polyamide. The ballto-powder (sample) ratio has a major effect on the transmitted mechanical energy. This has been studied by different investigators from a value as low as 1:1 to as high as $\sim 200: 1$. For mills produced by SPEX ${ }^{\circledR}$ this number is usually 10:1[84]. 
A serious problem that usually occurs in mechanochemical research is contamination. The small size of milled particles, the availability of large surface area and the formation of new surfaces during milling all contribute to the contamination of the powder. This can be solved by using special materials as components of the vials and grinding balls lowering the Fe contamination of the samples.

\subsubsection{Theories and models}

In the history of mechanochemistry many models and theories have been developed.

\subsubsection{Hot-spot theory}

This theory is the result of the first attempt to explain the reason of mechanical initiation of chemical reactions developed by Bowden, Tabor and Yoffe. It has been found that an important cause of mechanically initiated reactions, is the friction processes taking $10^{-4}-10^{-3} \mathrm{~S}$ and temperatures of over $1000 \mathrm{~K}$ can occur over a surface of

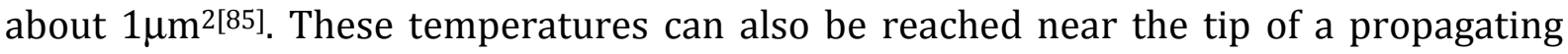
crack. Later this theory was expanded for other processes, like oxidation of metals. However, the controversy concerning the possibility of an increase in temperature at or on the friction surface has still not ended. Judging from indirect features, centers with a high temperature exist only under extreme conditions. In order to study the chemical processes at the tip of the propagating crack, a special setup has been used allowing a crystal to be cleaved directly in the vicinity of the ionic source of a mass spectrometer. The results show that during the cleavage of inorganic crystals (calcite, magnesite, cerussite, lead and sodium azides) gas evolution can be substantial suggesting that high temperatures exist at the crack tip.

However, since in brittle substances the rate of crack propagation can approach the sound velocity, the life-time excitation on the chemical bond must be $10^{-13} \mathrm{~s}$. It is evident that under these conditions, the term temperature can be used only symbolically. Later, it was proved that the processes occurring at the tip of a crack during the cleavage of a crystal may proceed by different mechanisms depending on the speed of crack motion [86]. 


\subsubsection{Magma-Plasma Model}

In the 1967 the magma-plasma model was proposed as the first comprehensive model in mechanochemistry[87]. According to it, large quantity of energy is set free at the contact spot of colliding particles. This energy is responsible for the formation of a special plasmatic state characterized by the emission of fairly excited fragments of solid substance, electrons and photons over a short time scale. The surface of colliding particles is rather disordered, and local temperatures can reach more than $10000 \mathrm{~K}$. Thiessen et al. distinguish the reactions, which occur in the plasma from the reactions taking place at the surface of the particles during the significantly excited state or immediately after relaxation. These considerations led to an important conclusion: these reactions do not obey a single mechanism.

\subsubsection{The hierarchic model}

This model was created as the perfection of the magma-plasma model. A concept of "hierarchy" of energetic states was elaborated, where a large number of excitation processes occur due to mechanical activation, which are characterized by different relaxation times (Table 1 )

Table 1.: Relaxation times of excitation processes in mechanically activated solids [81]

\begin{tabular}{cc}
\hline Excitation process & Relaxation time \\
\hline Impact process & $>10^{-6} \mathrm{~s}$ \\
Triboplasma & $<10^{-7} \mathrm{~s}$ \\
Gaseous discharge & $\sim 10^{-7} \mathrm{~s}$ \\
"Hot spots" & $10^{-3}-10^{-4} \mathrm{~s}$ \\
Electrostatic charging & $10^{2}-10^{5} \mathrm{~s}$ \\
Emission of exoelectrons & $10^{-6}-10^{-5} \mathrm{~s}$ \\
Triboluminescence & $10^{-7}-10^{3} \mathrm{~s}$ \\
Lattice defects & $10^{-7}-10^{6} \mathrm{~s}$ \\
Dislocation motion & $10^{5} \mathrm{~cm} / \mathrm{s}$ \\
Lattice vibrations & $10^{-9}-10^{-10} \mathrm{~s}$ \\
Fracture formation & $10-10^{3} \mathrm{~cm} / \mathrm{s}$ \\
Fresh surface & at $1.310^{-4} \mathrm{~Pa}: 1-$ \\
& $10^{2} \mathrm{~s}$ \\
Lifetime of excited metastable states & at $10^{5} \mathrm{~Pa}:<10^{-6} \mathrm{~s}$ \\
\hline
\end{tabular}

The most highly excited states having the shortest excitation times stand at the beginning and the numerous other states with smaller excitation incorporate themselves according to their temporal occurrence in the dissipation phase into the model. 
Long-lived states including defects and dislocations have been analyzed by equilibrium thermodynamics ${ }^{[88]}$. Mechanically disordered solids have an actual free energy content $(G)$, which is higher than the equilibrium free energy ( $G^{*}$ ) (Equation (6)).

$$
\mathrm{G}=\mathrm{G}^{*}+\mathrm{G}^{\mathrm{E}}
$$

The excess free enthalpy is composed of the contributing defects and their disturbance enthalpy with major contributions from step and screw dislocations, outer specific surface, particle size of primary crystallites and amorphous regions and different phases.

\subsubsection{Dislocation and phonon theory}

The principle of dislocation theory is that the mechanical action on solid substances gives rise to dislocations, which come to the surface and, subsequently, they become areas with increased chemical reactivity. The motion of dislocations in solid substance is accompanied by the formation of phonons due to interactions between dislocations and other dislocations, defects, admixtures or interfaces. The phonon theory emphasizes the distribution, the mutual effect and the origin of phonons in the course of disordering of the solid substances during milling.

\subsubsection{Theory of short-lived active centers}

The theory is based on the idea that new surfaces arisen during mechanical treatment is unable to stabilize in the $10^{-9}-10^{-11} \mathrm{~s}$ of thermal excitation. During the $10^{-4}-10^{-7} \mathrm{~s}$ required for stabilization, chemical bonds can rearrange, the electric surface relief occurs and further relaxation processes proceed. The relaxation of excess energies are strongly related to the decay of the short-lived centers. In vacuum, this relaxation is due to rearrangement of chemical bonds, whereas in chemically active medium the interactions of short-lived centers with the molecules of the surrounding medium are responsible for the relaxations. This is an exothermic process, which may be accompanied, e.g. by luminescence or other phenomena involving the release of energy[89].

\subsubsection{Impulse model}

The idea behind the model is that the kinetics of the reaction is determined by the time, in which the substances are liable to be in contact with the milling balls having an 
impulse effect. This time is different from the overall time of milling and is connected to the temperature rise during the impulse.

In mills, the formation of stress field and its relaxation occur at regular intervals by subjecting a solid to a sequence of mechanical pulses one after the other. Every pulse is characterized by the formation of stress fields in the region, being treated and the relaxation of this stress field leading to various physical and physico-chemical consequences. ${ }^{[90]}$

Besides these models, there are other models and theories, which are concerned with the mechanism of the mechanochemical reactions, like the theory of the energy balance, which states that the individual mill parameters as well as the different mill types lead to characteristic changes in the crystal lattice of solids ${ }^{[88]}$. Or the analogy model, which is based on the similarity of the energy transfer in mills with the energy transfer in an electric circuit[91].

\subsubsection{Mechanical activation}

The term of mechanical activation was introduced, by Smékal[92], and it was regarded as a process involving an increase in the reactivity of the substance remaining chemically unchanged. If the activation brings about a change in the composition or the structure, then, we are talking about a mechanochemical reaction. In this case, the mechanical activation initiates the reaction. As an improvement the behavior of the solids treated with mechanical energy was considered from the view-point of three main aspects: structural disordering, structural relaxation and structural mobility[93]. In real conditions the effect of these three factors cannot be separated, they affect the reactivity of the solids simultaneously. The mechanical activation is defined as an increase in reactivity due to stable changes in solid structure.

Structural relaxations play an important role in mechanical activation. These relaxation processes are heating, formation of new surfaces, aggregation, recombination, adsorption, imperfection, chemical reaction between particles, etc.[94]. The rate of these relaxation processes may be vastly different and the processes can change from one way of relaxation to the other (Figure 7). Considering these, activation can be regarded as a multi-step process with changes in the energetic parameters and the amount of accumulated energy of solids in each step. The four processes are as follows: the 
accumulation of defects, amorphization, the formation of metastable polymorphous forms, and chemical reaction, are united by the term of mechanical activation.

Juhász proposed that processes under the influence of mechanical activation can be subdivided into primary and secondary ones[94]. The primary processes like the increase in internal and surface energy, the increase in surface area, the decrease in the coherence energy of solids, generally increase the reactivity of the substance. The secondary processes like, aggregation, adsorption and, recrystallization, take place spontaneously in activated systems and may appear even during milling or after milling is completed.

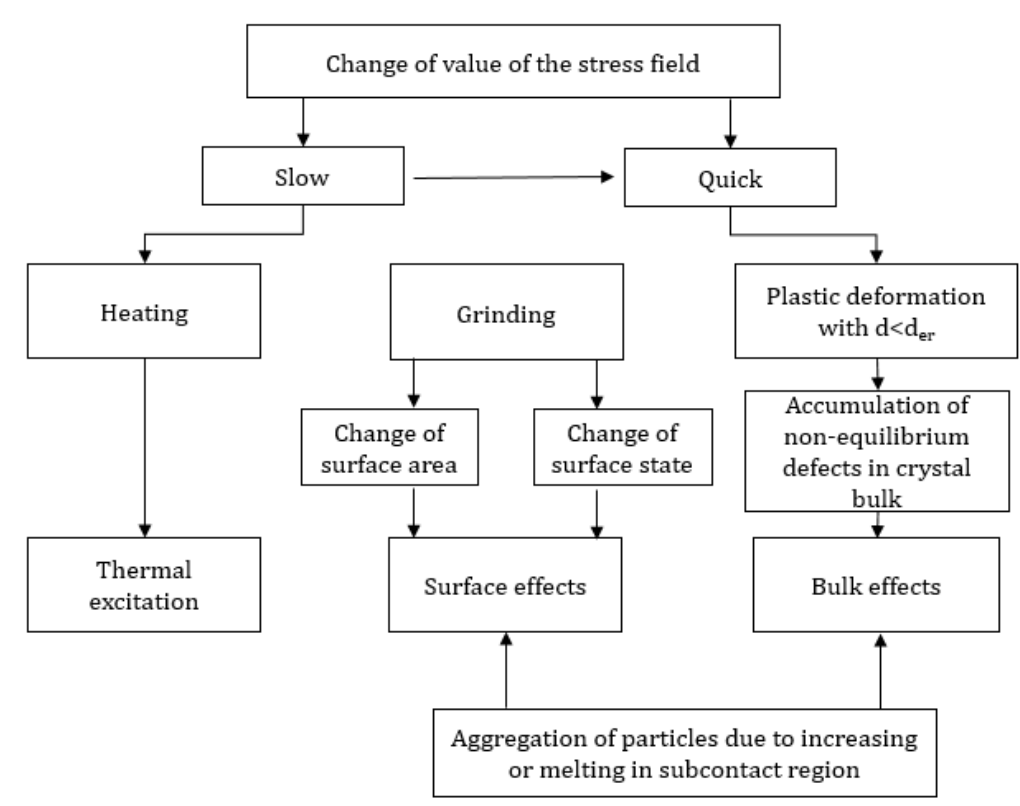

Figure 7. Flow sheet of changes of relaxation processes ${ }^{[90]}$

\subsubsection{Mechanochemical reactions}

Typical mechanochemical reactions are those activated by co-grinding or milling of powder materials. To understand these reactions, one must first get familiar to the processes occurring during milling. In the course of high-energy milling process, gradual deterioration of efficiency is observed. Three stages of this process can be distinguished. The first one is the Rittinger stage, in which the interaction of particles can be neglected. The second is the aggregation stage, where the new surface area produced is not proportional to the energy due to the particle interaction, aggregation. The third stage is the agglomeration stage, in which the increase in dispersion first drops to a negligible value, and then stops altogether. In the second stage the aggregates are mechanically connected via van der Waals forces of the magnitude of $0.04-4 \mathrm{~kJ} / \mathrm{mol}$, while in the third 
stage the particles are kept together by chemical bonds of the magnitude of 40$400 \mathrm{~kJ} / \mathrm{mol}$. Mechanochemical reactions and changes in the crystal structure mainly occur at this stage (Figure 8).

From the viewpoint of synthetic chemistry, an important observation is that substances can react following significantly different pathways in the solid state than they would do in solution, leading to new products or much higher selectivities[95].

These reactions have some difficulties, the reaction conditions are controlled indirectly, by varying the grinding time, temperature, pressure, grinding frequency etc. Furthermore, the heat generated in the course of the mechanochemical process can induce local melting of crystals or melting at the interface between the different crystals, thus the reaction might take place in the liquid phase even though finally, the products are recovered as solid substances.

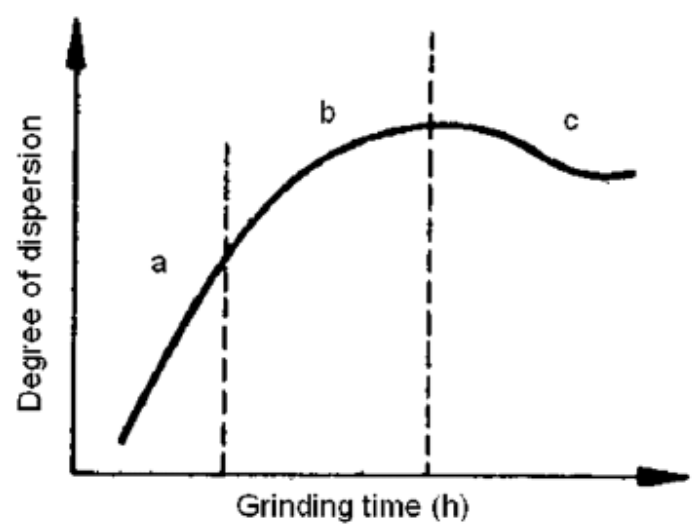

Figure 8. The three stages occurring during high-energy milling of solids: a - Rittinger stage, b - aggregation stage and c - agglomeration stage[96]

One should also keep in mind that mechanical stress increases surface area by fracturing the crystals, and facilitates interpenetration and reactions, which mainly depends on the ability of molecules to diffuse through the crystal surfaces. Mechanochemical methods are commonly used at industrial level mainly with inorganic solids [97] [98]. But there are also registered synthesis of pharmaceutically important compounds via this method such as the $\beta$-cyclodextrin inclusion complexes containing ketoprofen[99], ketoconazole[100] or carbaryl[101].

In comparison with inorganic solid-state reactions, the interactions in organic molecular crystals are mainly of the non-covalent type, e.g., van der Waals, hydrogen bonds and $\pi$-stackings ${ }^{[102]}$, although there are examples of mechanically-induced formation of covalent bonds (discussed later on). No significant activation energies have to be introduced in the exoenergetic reactions of molecular crystals. It is also important 
to note that, products formed by co-milling of crystals in the absence of liquid can be different from those obtained from solutions or melts.

Among the earliest investigations of solid-state organic reactions were reactions between naphthalene, phenanthrene, anthracene, naphtols, and other substituted hydrocarbons and picric acid[103]. The kinetic studies of these reactions show that they were diffusion controlled, and the diffusion took place by surface migration. For organic reactions in the solid state, various types of mills providing high energy milling (vibration mills, planetary ball mills, attritors) have been tested. It was established that many types of organic reactions can be accomplished in these instruments. Furthermore, in some cases, the mechanochemical method was proven to be not only simpler and faster than the traditional synthesis, but more selective as well[104]. Organic mechanochemical reactions (more than 1000 stoichiometric reactions have been recorded) can proceed with $100 \%$ yield and do not require purifying workup, they are solvent- and waste-free[105]. This aspect is very tempting for the industry; as the consequence, some of these reactions were successfully scaled up using industrial mills.

Here, some examples are given, for mechanochemical reactions of organic compounds. Glucose and urea forms stoichiometric crystalline 1:1 complex within minutes in a planetary mill (Equation (7)). Without milling, small amounts of products could only be obtained by tedious crystallization taking six months.

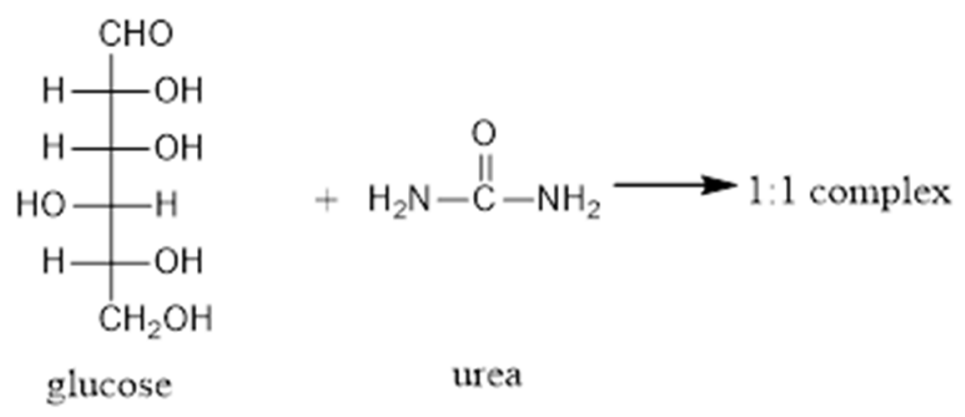

Sodium tartrate is a well-known food additive (E 335). The crystals are in use for the preparation of powders or tablets for refreshing drinks. The common, water-based preparative techniques are burdened by the energy consuming evaporations. In the mechanochemical synthesis of this product (Equation (8)), no excessive heating was observed, and the liberated $\mathrm{CO}_{2}$ was released by a safety valve in the mill. 


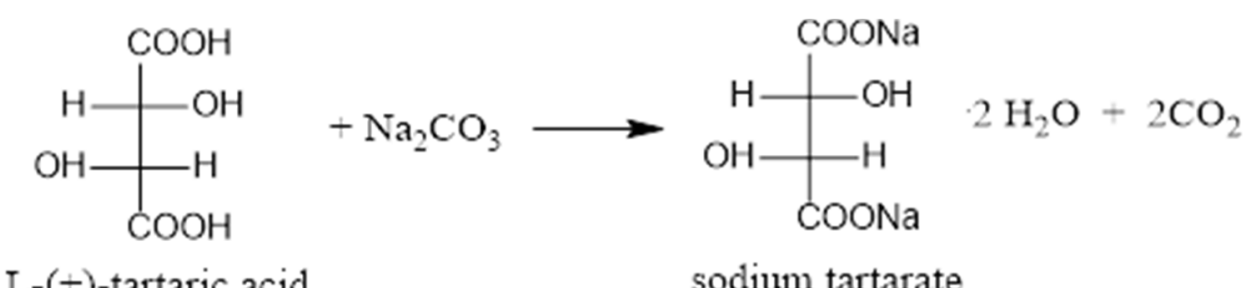

L-(+)-tartaric acid

sodium tartarate

In these two cases, although we can talk of mechanochemical reactions, there were no newly formed covalent bonds connecting the molecules. Nevertheless, the formation of covalent bonds can be achieved by mechanochemical methods. Schmeyers et al. reported the quantitative synthesis of hydrated azomethines by co-grinding solid anilines and solid benzaldehydes without passing through liquid phases ${ }^{[106]}$ of any sort.

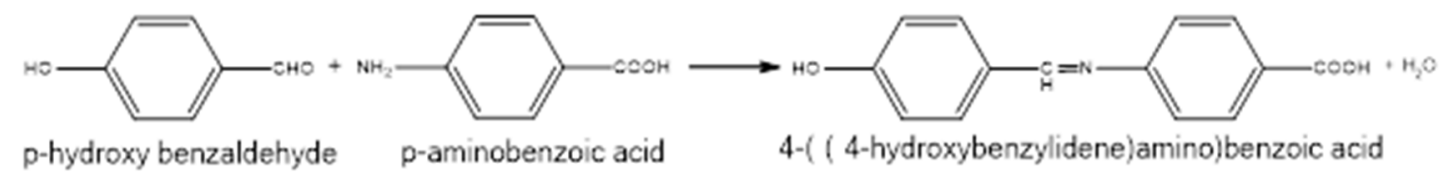

The water formed during the condensation reaction (Equation (9)) does not interfere with the procedure, neither in the small or the large scale, since it is incorporated in the lattice of the product. The reaction proceeds smoothly and efficiently at near ambient conditions, while in the solution-based synthesis $12 \mathrm{~h}$ boiling in ethanol is required[107].

Using solvent-free techniques the synthesis of heterocyclic ring systems are also possible. For instance, phenylacyl bromide and thiourea were milled at room temperature to give the aminothiazole hydrobromide salt (Equation (10)). The same reaction under solution-based conditions is a complicated cascade of reaction sequence composed of substitution, cyclization, dehydration, and isomerization.

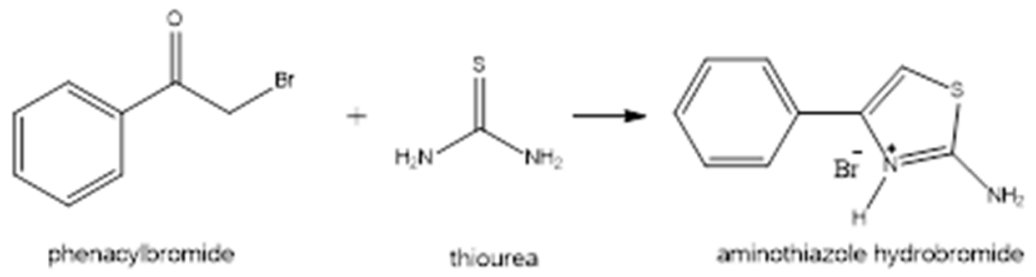

It has been demonstrated that solvent-free mechanochemical techniques are particularly advantageous when applied to fullerenes, since the poor solubility of these compounds usually requires large quantities of solvent for reaction in solution. The possibility of direct contact between the non-solvated reactants affords reaction pathways, which are not accessible, or difficult to attain, in solution. In the reaction of fullerene with $\mathrm{KCN}, \mathrm{KOAc}$, and $\mathrm{K}_{2} \mathrm{CO}_{3}$, the solid-state process selectively gives the $[2+2]$ 
dumbbell-shaped dimer $\mathrm{C}_{120}{ }^{[108]}$, whereas in the solution-phase reaction with $\mathrm{KCN}, \mathrm{C}_{60}$ is simply cyanated. Using solid-state reactions, products could be produced that could not be synthesized via solution-based methods, such as the reaction of $\mathrm{C}_{60}$ with phthalazine (2,3-diazanaphthalene). Here, a new fullerene dimer with a bicyclic framework is formed under the mechanochemical solid-state reaction conditions ${ }^{[109]}$.

\subsection{Applications of LDHs}

Due to the compositional diversity of the layers and the interlayer anions, LDHs can be used in a variety of application fields. Since giving an exhaustive description is virtually impossible, in the followings, I give only highlights from some areas related to my experimental work.

\subsubsection{Catalytic applications}

The catalytic reactions are highly desirable, since catalysts can increase the reaction rate, the conversion rate and the selectivity of certain products. For many years, in the majority of the reactions, homogenous catalysts were applied because of their very high selectivities; however, due to their recyclability and high efficiency, heterogeneous catalysts took over in many reactions. In heterogeneous catalysis, LDHs can act as catalyst supports, catalyst precursors or the actual catalysts, evidencing why the catalytic applications belong to the main field of applications.

On the controlled thermal decomposition of the LDHs, mixed metal oxides can be obtained, having high surface areas and basic (alkaline) properties. The thermal treatment of the LDHs at low temperatures can lead to a synergetic effect between the elements in spinel-like or mixed oxide structures, thus giving the opportunity to fine control the nature of the active sites and their environment, as well as the textures and stabilities of the catalysts. These mixed oxides usually have good catalytic activities. Here, LDH behaves as a Brønsted-type catalyst, and it has been applied to aldol[110] and Knoevenagel[111] condensations, epoxidation of olefins ${ }^{[112]}$, halide exchanges[113], phenol hydroxylation ${ }^{[114]}$, Michael additions ${ }^{[115]}$ and transesterifications ${ }^{[116]}$. In these reactions, the mixed oxide catalysts are obtained through the thermal decomposition of the LDH. The ones derived from hydrotalcite, are particularly interesting, because of the presence of the $\mathrm{Mg}^{2+}-\mathrm{O}^{2-}$ acid base pairs leading to specific catalytic properties. They can be applied in diverse reactions, such as aldol, Claisen-Schmidt and Knoevenagel 
condensations, transesterification, alkylation of phenol by alcohols, oxidation of thiols, Baeyer-Villiger oxidation of ketones, polymerization of lactones, methanol synthesis, epoxidation of activated olefins with $\mathrm{H}_{2} \mathrm{O}_{2}$, and reduction of aldehydes and ketones by hydrogen transfer from alcohols[117].

For $\mathrm{C}-\mathrm{C}$ bond formation in condensation reactions, large amounts of liquid bases were used as catalysts on the industrial scale. Their replacement with environmentally benign basic solids of similar activities and selectivities was a real challenge; however, basic oxides, such as $\mathrm{MgO}, \mathrm{CaO}, \mathrm{BaO}$ and their mixtures, meant possible options. They have good activities in these reactions. The generally accepted mechanism for the aldol condensation of aldehydes and ketones involves proton abstraction through basecatalyzed reaction, leading to the formation of enolate-type species first, then, its nucleophilic addition to another (neutral) molecule, then, the dehydration of the aldol thus formed to yield an $\alpha, \beta$-unsaturated compound. This mechanism reveals that, aside from the basic sites of adequate strength, acid sites are also required for the dehydration[118]. It is clear that the balance between the basic and the acidic sites is a key parameter for the catalytic properties.

The catalytic properties of the LDHs can be evidenced even when the layered structure is not destroyed. In this case, the layers, the intercalated anions and water could participate in the reactions, giving, in some cases, even higher reactivity than the mixed oxides derived from the heat treatment of the LDHs[119]. Furthermore, there are a lot of examples when the active catalyst results from the intercalation of specific anionic species in the interlayer space of the LDH acting as the host structure. The utilization of the LDHs as host structures for different catalysts is quite common. This way shapeselective chemical, electrochemical or photocatalysts can be obtained. Among other advantageous features, the stabilization of homogenous or biomimetic catalysts is possible via intercalation in LDHs, and, thus the service life of these molecules can be increased. The easy recovery and recycling are additional assets. LDHs also provide the possibility of preparing supported catalysts with concentrations of the active phase and activities higher than those obtained with conventional support. Most interesting is the variability of the transition metal ions in the brucite-like layer enabling the LDHs to show a spread spectrum of catalytic activity for oxidation and reduction, exemplified in the applications for total oxidation of volatile organic compounds, $\mathrm{H}_{2}$ production, $\mathrm{DeNO}_{\mathrm{x}}$ and $\mathrm{DeSO}_{\mathrm{x}}$ reactions and CNT formation[120]. 
Both calcined[121] and uncalcined[122] LDHs are effective supports for noble metal catalysts. Choudary et al.[123] studied $\mathrm{Pd}(0)$ catalysts supported on MgAl-LDHs prepared by ion exchange with $\mathrm{PdCl}_{4}{ }^{2-}$, followed by reduction. They observed that the catalysts, used in ionic liquids, not only exhibited higher activity and selectivity than the homogeneous $\mathrm{PdCl}_{2}$ system in the Heck olefination of electron-poor and electron-rich chloroarenes, but also showed superior activity in the $\mathrm{C}-\mathrm{C}$ coupling reactions of chloroarens compared with other heterogeneous catalysts involving $\operatorname{Pd}(0)$ on supports such as silica, alumina or Merrifield's resin. Polyoxometallate (POM) and sulphonatosalen-based (Salen) catalysts have been intensely investigated for oxidizing $\mathrm{C}=\mathrm{C}$ double bonds with $\mathrm{H}_{2} \mathrm{O}_{2}$ in systems free of organic solvents. These two catalytic anions can be intercalated and thus confined in the interlayer spaces of LDHs, leading to high activity and selectivity in the epoxidation of various olefins. POMs are restricted in the interlayer may be responsible for the regioselective epoxidation of one $\mathrm{C}=\mathrm{C}$ bond over another in the same organic molecule. For instance, unusual stereo- and regioselectivities have been observed in the epoxidation of terpene, 3-carene, squalene and (-)-carveol[124].

The secondary and tertiary amines can be oxidized with various oxidizing reagents over the catalyst with certain alkalinity. MgAl-LDH is a weak base, and can be made stronger by intercalating $\mathrm{OBu}^{-}$anion[125]. This catalyst showed an activity similar or superior to $\mathrm{KOBu}$ and $\mathrm{NaOH}$ for the $\mathrm{N}$-oxidation of $\mathrm{N}$-methylmorpholine and dibutylmorpholine using $\mathrm{H}_{2} \mathrm{O}_{2}$ as oxidant and benzonitrile-methanol mixture as solvent. These LDH-based catalysts are all recyclable, without any obvious loss of activity.

\subsubsection{Environmental applications}

The use of the LDHs in environmental applications arose from one of the main properties of LDHs, anion exchange that is. LDHs can uptake a variety of contaminants and toxic substances directly from the environment via anion exchange, reconstruction of the layers and absorption. Since serious contamination of water arises from various anionic compounds, and cultivated soils extensively develop acidic property, attempts to remove pesticides in anionic form by adsorption/absorption on/in LDHs have steadily increased.

Through anion exchange of chloride- and nitrate-containing LDHs, the phosphate anion, which is the major factor in surface water eutrophication, can be captured[126]. Competing anions affect phosphate uptake, e.g. nitrate causes slight decrease in 
phosphate removal, whereas sulfate brings about $12-13 \%$, and carbonate does $33 \%$, reduction. These numbers can be traced back to the liotropic series reflecting the strength of the interaction between different anions and the layers (Equation (3)). The higher is the strength of the intercalation, the higher is the decrease in the phosphate reduction.

Only a few of natural antibiotic substances are available for pest control mainly because of their inherent properties, such as easy degradability, high minimum inhibition concentration for practical application and often, extremely low availability. The hybridization of natural antibiotic substances with layered double hydroxides could be an alternative for green formulation of pesticides[127].

In the water industry and waste water purification, the presence of humic substances is a major problem. During the removal process of heavy metal contaminants in soil remediation, and the removal process of organic pollutants in drinking water treatment, humic acids often reduce the removal of the target substances through their adsorption onto adsorbents and/or complex formation with the target substances. Due to their good solubility in water and their wide range of distribution in molecular weight and size, their removal via conventional adsorbents is difficult. LDHs, however, are ideal choice for their removal, which can occur by both adsorption onto the hydroxyl groups of the layers and intercalation in the interlayers space ${ }^{[128]}$. Their advantages over conventional anion exchanging resins are their higher anion-exchange capacities for certain oxy anions and their good thermal stabilities. At the same time, they can be fully regenerated in a short time.

The recovery of $\mathrm{CO}_{2}$ from power-plant flue gases is considered to be the first step in reducing total $\mathrm{CO}_{2}$ emission. $\mathrm{LDHs}$ have good capacity for $\mathrm{CO}_{2}$ adsorption, dependent on the micropore volume, interlayer spacing and layer charge density of the substances specifically applied. The adsorption of $\mathrm{CO}_{2}$ into these materials were investigated as a possible method for recovery of carbon dioxide from hot gas streams[129].

\subsubsection{Pharmaceutical and cosmetic applications}

The pharmaceutical applications of the LDHs exploit their acid buffering effect and their anion-exchange capacities. Hydrotalcite has pharmaceutical applications as an ingredient in sustained-release pharmaceuticals containing nifidipine. The role of the LDH was the stabilization of the active substance. Furthermore, they were applied for 
the preparation for aluminum magnesium salts of antipyretic, analgesic and antiinflammatory drugs ${ }^{[130]}$.

The most studied area of the LDHs from the pharmaceutical point of view, is the use of these host materials as a storage and delivery devices for biologically important species. Many bioactive substances are based on different variations of carboxylic acids, thus, they can be made anionic easily, and as such, they are suitable for intercalation into LDHs. This way, a variety of drugs have been incorporated into LDHs[131]. These composites may be good candidates for "controlled release formulations" (CRFs). This means that instead of taking doses of the drug regularly at given time intervals, CRFs allow the patient to take only tablets far less frequently. The delivery of the drug is slow, sustained, effective, and non-toxic, and concentrations of the drug may be retained at the effective level in the body over a long period of time. Significant contributions have been made to this area by Choy et al. They have successfully intercalated folic acid and methotrexate (MTX), which are both drugs used in cancer treatment, into MgAl-LDH[132]. It was demonstrated by an in vitro bioassay that in the initial stages of the administration of the drug, the intercalated MTX has a significantly higher efficiency against tumor cells than MTX alone. In the hybrid system MTX can reach the tumor cell membrane without any early decomposition, since the MTX molecules are stabilized and protected in the interlayer space of the LDH lattice. The LDH not only plays a role as a biocompatible-delivery matrix for drugs, but also facilitates a significant increase in the delivery efficiency. In vivo studies have demonstrated that LDH particles have little systematic effect at low doses, and thus, they are likely to be suitable as drug delivery matrixes ${ }^{[133]}$.

LDHs can intercalate many important negatively charged biomolecules such as oligomers, single or double stranded DNA, and simple molecules like nucleotides[134]. DNA strands are very susceptible to degradation and denaturation during manufacture processes and storage. The intercalated DNA on the other hand was safely protected against harsh conditions including strongly alkaline, as well as weakly acidic environments[135]. The DNA can also be recovered easily by exposing the DNA intercalated LDH to acidic conditions. Further experiments have shown that vitamins may also be intercalated and discharged in a controlled fashion ${ }^{[136]}$.

The above-mentioned LDH characteristics, such as high adsorption capacity, excellent anion-exchange ability and stabilizing potential, make these materials 
desirable not only for pharmaceutical, but cosmetic applications as well. The high adsorption capacity can be used to remove skin exudates and to encapsulate skin sensitive coloring and UV-screening agents, while the anion-exchange ability can be useful to protectively deliver active substances for anti-wrinkling and skin regeneration. LDHs can stabilize unstable molecules often used in cosmetics, such as retinoic acid, ascorbic acid, tocopherol, etc. They can also improve the rheological properties of different products, especially emulsions. The applications of the LDHs in cosmetics are not so widely studied as in pharmaceutical research and development; nevertheless, there are some studies discussing the potential of LDHs in cosmetics ${ }^{[137] ~[138] ~[139] . ~}$

\subsubsection{Applications in the polymer industry}

Polymers are one of the most popular and widely used compounds of the chemical industry. This need of polymers generated comprehensive research for the development of more economic preparation and modification of the properties of these materials. LDHs can be utilized as additives in both the polymerization process and in the modification of the properties of the already synthesized polymers.

Buffet et al. reported the use of various LDHs as catalyst supports in the polymerization reaction of the ethylene, exploring new opportunities to affect the properties of polyethylene ${ }^{[140]}$. The polymerization process can also occur in situ, between the layers of the LDHs. In this case, the appropriate monomers are intercalated, then, polymerization is initiated. Using this method polyaniline ${ }^{[141]}$ and polyacrylate ${ }^{[142]}$ have been successfully prepared. This type of in situ radical polymerization process makes it possible to tune the tacticity and the molecular weight of the resulting polymer by varying the layer-charge density and the particle size of the host structure. In addition the spatial confinement is believed to increase the degree of polymerization. The incorporation of a polymer can also be achieved, for this different methods can be used, such as co-precipitation, ion exchange, surfactant-mediated incorporation, hydrothermal treatment, reconstruction, or delamination followed by restacking[143].

The LDH-polymer composites usually exhibit better terminal stability than their pristine inorganic compounds, leading to their potential application as flame-retardant composites ${ }^{[144]}$.

LDHs are frequently used as polymer additives. In these cases, the LDHs are the guest materials and their purpose is to improve the mechanical properties of the 
composites. After the modification of the polymers with LDHs, the strength and heat resistance, gas permeability, flammability and biodegradability have improved[145]. These nanocomposites were prepared from the delamination of the hydroxide sheets in a polymer matrix ${ }^{[5]}$.

Polyvinylchloride (PVC) undergoes autocatalytic dehydrochlorination, when exposed to heat or UV light, becoming brittle and exhibiting a change in color. Synthetic LDHs are commercially used as acid neutralizers in stabilizer packages for PVC. Adding LDHs, 6-anilino-1,3,5-triazine-2,4-dithiol and zinc stearate to PVC, reduces the rate of their discoloration. 


\section{THE AIMS OF THE DISSERTATION}

The preparation and the intercalation properties of layered double hydroxides using solution-based methods have been investigated widely in the literature. In this work, a less frequently used method was used for these purposes, mechanochemistry that is. At the beginning of the work, several goals were set out:

- The mechanochemical preparation of $\mathrm{Ca}(\mathrm{II}) \mathrm{Al}(\mathrm{III})-\mathrm{Ca}(\mathrm{II}) \mathrm{Fe}(\mathrm{III})-\mathrm{LDHs}$, and the optimization of the synthesis processes.

- The synthesis of Ca(II)Sn(IV)-LDH.

- Functionalizing the LDHs via intercalating various amino acids mechanochemically, and the optimization of the intercalation processes.

- Characterization of these materials with as many methods as possible. 


\section{EXPERIMENTAL PART}

\subsection{Materials and apparatus}

All materials used for the experiments were used as received without further purification, these materials are: Calcium hydroxide $\left(\mathrm{Ca}(\mathrm{OH})_{2}\right.$, Sigma-Aldrich $\left.\geq 95 \%\right)$, Calcium chloride $\left(\mathrm{CaCl}_{2}\right.$, Sigma-Aldrich $\left.\geq 99 \%\right)$, calcium nitrate $\left(\mathrm{Ca}\left(\mathrm{NO}_{3}\right)_{2} \cdot 4 \mathrm{H}_{2} \mathrm{O}\right.$, SigmaAldrich, $\geq 99 \%$ ) iron chloride $\left(\mathrm{FeCl}_{3} \cdot 6 \mathrm{H}_{2} \mathrm{O}\right.$, Molar Chemicals, puriss special), iron nitrate $\left(\mathrm{Fe}\left(\mathrm{NO}_{3}\right)_{3} \cdot 9 \mathrm{H}_{2} \mathrm{O}\right.$, Sigma-Aldrich, puriss $\left.\geq 99 \%\right)$, tin chloride $\left(\mathrm{SnCl}_{4} \cdot 6 \mathrm{H}_{2} \mathrm{O}\right.$, Sigma-Aldrich, puriss $\geq 98 \%$ ), cobalt chloride $\left(\mathrm{CoCl}_{2} \cdot 6 \mathrm{H}_{2} \mathrm{O}\right.$, Sigma-Aldrich, 98\%), aluminum hydroxide $\left(\mathrm{Al}(\mathrm{OH})_{3}\right.$, Sigma-Aldrich, a.r. grade), aluminum chloride $\left(\mathrm{AlCl}_{3} \cdot 6 \mathrm{H}_{2} \mathrm{O}\right.$, Sigma-Aldrich, 99\%), sodium hydroxide ( $\mathrm{NaOH}, \mathrm{VWR}$, a.r. grade), hydrogen chloride ( $\mathrm{HCl}$, SigmaAldrich, $\geq 37 \%$ ) L-Cystine (L-Cys-Cys, Sigma-Aldrich, $\geq 99 \%$ ), L-Cysteine (Cys, SigmaAldrich, $\geq 98 \%$ ), DL-valine (DL-Val, Sigma-Aldrich, $\geq 97 \%$ ), L-Tyrosine (L-Tyr, SigmaAldrich, $\geq 97 \%$ ).

For the mechanochemical syntheses performed by milling, a Retsch MM 400 mixer mill was used, with two stainless steel grinding jars of $50 \mathrm{~cm}^{3}$ internal volumes each, and stainless steel grinding balls of $20 \mathrm{~mm}$ in diameter. During the syntheses the grinding frequency and the grinding time could be varied.

\subsection{Preparation of concentrated and carbonate-free $\mathrm{NaOH}$ solution}

Concentrated $\mathrm{NaOH}(\sim 20 \mathrm{M})$ stock solution was prepared from MilliQ water (Milipore) and analytical grade solid $\mathrm{NaOH}$, its carbonate content was minimized. At this base concentration the solubility of the $\mathrm{Na}_{2} \mathrm{CO}_{3}$ is negligible, and after filtration (polysulfone Nalgene filter) under inert $\left(\mathrm{N}_{2}\right)$ atmosphere, carbonate-free $\mathrm{NaOH}$ solution could be obtained. The exact density of the solution was determined by a pycnometer. The concentration of the solution was calculated from the known density vs. concentration curve of sodium hydroxide[146]. This stock solution was kept in airtight, caustic resistant Pyrex bottle, and was then diluted to the desired concentration under inert $\left(\mathrm{N}_{2}\right)$ atmosphere.

\subsection{Synthesis of pristine LDHs}

The syntheses of pristine LDHs were carried out by different methods, depending on the type of the LDHs to be synthesized. In the syntheses of Sn(IV) containing LDHs both solution based, and mechanochemical methods have been applied. In the co- 
precipitation method LDHs were prepared via dropwise addition of the two metal salt solutions $\left(\mathrm{CaCl}_{2}\right.$ or $\mathrm{CoCl}_{2}$ and $\left.\mathrm{SnCl}_{4}\right)$ in various molar ratios to a vigorously stirred $\mathrm{NaOH}$ solution. The $\mathrm{pH}$ of the solution containing the two metal ions was set to 1.71 using a 20 $\% \mathrm{~m} / \mathrm{m} \mathrm{HCl}$ solution, in order to prevent the hydrolysis of the Sn salt. The concentration of $\mathrm{NaOH}$ was $1 \mathrm{M}$, the quantity was calculated to have a final $\mathrm{pH}$ of 9 . The mixture of the two solutions was stirred for 24 hours. The precipitate was filtered until air dry with the aid of caustic resistant vacuum filter unit (Nalgene, USA) equipped with an appropriate membrane (Versapor $0.45 \mu \mathrm{m}$, Pall Corporation). The solid reaction products were kept at room temperature in desiccators over dry $\mathrm{SiO}_{2}$. Some of the samples have been aged for 6 hours at a temperature of $70^{\circ} \mathrm{C}$.

The second method, which is a novel technique for these systems, was the mechanochemical route. The mechanochemical syntheses were applied in two ways: by using a mixer mill or a simple agate mortar. The rotation frequency of the mixer mill was $11.6 \mathrm{~s}^{-1}$ and was kept constant throughout the syntheses, just like the total weight of the precursors ( $3 \mathrm{~g}$ ). Two methods were investigated: the one-step and the two-step millings. In the former one, only dry milling was performed, and the precursors were ground for 3 hours. In the latter one, in addition to dry milling, wet milling was also applied. The precursors were ground when dry for 1 hour, then $0.7 \mathrm{ml}$ of water was added, which was followed by a 2-hour long wet grinding. After the synthesis the products were kept at room temperature in a desiccator over dry $\mathrm{SiO}_{2}$.

When using the agate mortar, the results of the above-mentioned methods were meant to be reproduced, thus the methods applied were analogous to the ones mentioned above in both the one-step (dry) and two-step (dry and wet) millings. In this case, the starting materials (3 g altogether) were ground until a uniform, fine powder was obtained, and then, the mixture was divided into two parts. One part was placed in a desiccator and was studied without further treatment. To the other part $0.35 \mathrm{ml}$ of water was added, then grinding was continued until a uniform and homogenous mixture was obtained. The product thus received was dried, and kept in a desiccator.

The preparation of the $\mathrm{Ca}(\mathrm{II}) \mathrm{Al}(\mathrm{III})-$ and $\mathrm{Ca}(\mathrm{II}) \mathrm{Fe}(\mathrm{III})-\mathrm{LDH}$ s was attempted using only mechanochemical methods. These are somewhat analogous to the mechanochemical methods presented above. They were carried out either by manual grinding, using a simple agate mortar, or by milling using a mixer mill. When using the agate mortar, the precursors were placed into the mortar and grinded for $5 \mathrm{~min}$. This 
was followed by the addition of a certain amount of $\mathrm{NaOH}$ solution or water, after which the mixture was ground for 1 additional hour.

A method similar to this was used in the syntheses performed in the mixer mill. The precursors were placed in the grinding jars and milled for $1 \mathrm{~h}$ (dry milling), after which a certain amount of water was added to the system, and, then, a $2 \mathrm{~h}$ grinding (wet milling) was applied. A set of parameters, the amount of added water and/or $\mathrm{NaOH}$ solution the ball/sample weight ratio, the grinding frequency, the dry milling time, and the wet milling time were systematically varied in order to obtain the LDH in as phasepure form as it was possible.

\subsection{Intercalation of the LDHs}

In every case, the intercalation of different amino acids into the layers of various LDHs was attempted via mechanochemical methods. A slightly modified two-step grinding procedure was applied. The first step was dry milling, where the precursors were ground for 1 hour; then, a certain amount of $\mathrm{NaOH}$ solution and the amino acid were added, which was followed by 2 hours of wet grinding. After this, the products were washed, dried and stored in a desiccator at room temperature. The addition of the precursors, the amino acids, and the $\mathrm{NaOH}$ into the grinding jars, as well as the sealing of the jars were performed under $\mathrm{N}_{2}$ atmosphere in a glove-box. This way, the disturbing $\mathrm{CO}_{2}$ could be excluded. In the syntheses the conclusions of the optimizations of the pristine LDH preparation were taken into account, thus in all the cases, the ball/sample weight ratio $(\mathrm{B} / \mathrm{S})$ was 100 .

The optimization of the intercalation process was attempted via the systematic change of several reaction parameters, such as the $\mathrm{NaOH}: \mathrm{Fe}$ molar ratio, the Fe:amino acid molar ratio, and different forms of the amino acid.

\subsection{Instrumentation and characterization methods}

\subsubsection{X-ray diffractometry}

Powder X-ray diffraction (XRD) patterns of the solid samples were registered in the $2 \theta=3-60^{\circ}$ range on Rigaku Miniflex II and DRON-2 instruments, using CuK $\alpha$ $(\lambda=1.5418 \AA)$ radiations in Bragg-Brentano geometry. Reflection positions were determined via fitting a Gaussian function. They were found to be reproducible within $0.05^{\circ}(2 \theta)$, therefore the uncertainty of the basal spacing was estimated as $\pm 0.01 \mathrm{~nm}$. 


\subsubsection{FT-IR spectroscopy}

The Fourier-transform infrared (FT-IR) spectra of the pristine, the organic anion intercalated LDHs were recorded on a BIORAD FTS-65A/896 spectrometer equipped with a DTGS detector in diffuse reflectance. Spectral resolution was $4 \mathrm{~cm}^{-1}$ and 256 scans were used for a spectrum. The spectra were baseline corrected and smoothed using the WIN-IR software package. The samples were finely ground and combined with $\mathrm{KBr}$ (without pressing into pellets).

\subsubsection{Raman spectroscopy}

Raman spectra were recorded on a BIO-RAD Digilab Division dedicated FT-Raman spectrometer equipped with liquid nitrogen cooled germanium detector and $\mathrm{CaF}_{2}$ beamsplitter. The excitation line was provided by a Spectra Physics T10-106C Nd:YV04 laser at $1064 \mathrm{~nm}$. The spectra were recorded in the $3600-100 \mathrm{~cm}^{-1}$ range with $4 \mathrm{~cm}^{-1}$ resolution. 1024 scans were collected for each spectrum. The excitation power was $280 \mathrm{~mW}$ at the sample position. The spectrometer was controlled by the BIO-RAD Win IR 3.3 software. The samples were placed in a standard NMR tube. Spectra were recorded at room temperature. Data were processed by the GRAMS/AI 7.00 software.

\subsubsection{Thermal analytical measurements}

Thermal analytical measurements (TG/DTG) were performed using a Setaram Labsys derivatograph working under $\mathrm{N}_{2}$ flow at $2^{\circ} \mathrm{C} / \mathrm{min}$ heating rate. Both the weight loss vs. temperature (thermogravimetric-TG) and the differential weight loss vs. temperature (differential thermogravimetric-DTG) curves were recorded. Approximately $20 \mathrm{mg}$ sample (measured accurately into a ceramic crucible sample holder) was applied in each experiment. Measurements were started right after removing the samples from the desiccators.

\subsubsection{Microscopic techniques}

The morphology of the samples was examined with scanning electron microscope (SEM - Hitachi S-4700 microscope with varying acceleration voltage). The samples were fixed on a double-sided adhesive carbon tape. They were coated with gold in order to obtain images with more contrast, using a sputter coater (Quorum Technologies 
SC7620). The thickness of the gold layer was a few nanometers. The approximate composition and the elemental map of the substances were investigated by a Röntec QX2 energy dispersive X-ray spectrometer (EDX) coupled to the microscope.

\subsubsection{X-ray absorption spectroscopy}

The X-ray absorption spectra (XAS) were measured at the Fe K-edge beamline I811 at the MaxLab facility in Lund, Sweden. The station is based on a superconductive undulator injection device connected to the $1.5 \mathrm{GeV}$ MAX II storage ring. This superconducting multipole wiggler beamline equipped with a water-cooled channel cut $\mathrm{Si}(111)$ double crystal monochromator can deliver at $10 \mathrm{keV}$, approximately $2 \times 10^{15}$ photons/s/0.1\% bandwidth with horizontal and vertical FWHM of 7and $0.3 \mathrm{mrad}$, respectively[147]. Abeam-size of $0.5 \mathrm{~mm} \times 1.0 \mathrm{~mm}$ (width $\times$ height) was used. The incident beam intensity $\left(\mathrm{I}_{0}\right)$ was measured with an ionization chamber filled with a mixture of $\mathrm{He} / \mathrm{N}_{2}$. Higher order harmonics were reduced by detuning the second monochromator to $70 \%$ of the maximum intensity. Data collection was performed in transmission mode. 300 mg samples were measured in Teflon spacers with Kapton tape windows. Data were treated by the Demeter program package[148] [149]. X-ray absorption spectra were normalized to an edge jump of unity and the removal of the background absorption was done. The Extended X-ray Absorption Fine Structure (EXAFS) data were $\mathrm{k}^{3}$-weighted and Fourier transformed in the range of $\mathrm{k}=2-10 \AA^{-1}$. The ranges for the backtransform were 1-3.5 $\AA$. The fitted parameters included the amplitude reduction factor $\left(\mathrm{S}_{0}^{2}\right)$, interatomic distances $(R)$, Debye-Waller factors $\left(\sigma^{2}\right)$ and energy shift $\left(\Delta \mathrm{E}_{0}\right)$. The coordination numbers $(\mathrm{N})$ were kept constant during each optimization, but a range of coordination numbers were used to find the best fit. Since this method is not characterization method, which can be used on a daily basis in every laboratory, a brief description of the methods principal will be given in the following.

Electronic and structural properties are of utmost importance for a fundamental understanding of the macroscopic and microscopic behavior of materials. For the exploring of these electronic and structural techniques, several tools and techniques have been developed. One example is synchrotron radiation sources, which were first built in the 1940s, but have been employed as an independent tool to investigate materials since some 40 years ago. When the X-ray interacts with the matter three different mechanisms contribute to its attenuation: photo-electric absorption, scattering, 
and pair production. The dominant interaction for relatively low photon energies is photoelectric absorption. Here one photon is absorbed from the beam because of its interaction with an atom. The photon energy is absorbed by the atom, which can be excited, with promotion of one or more electrons to higher bound energy levels, or ionized, with ejection of one or more electrons. The second interaction, weaker than photoabsorption at low energies, is scattering, a photon is deflected from the original trajectory by the collision with an atom. The scattering of one electron can be modified scattering (when the photon wavelength is modified by the scattering process) or unmodified (when the photon process is unmodified by the scattering process). The dominant interaction at high energies is pair production: the photon annihilates, giving rise to a pair $\mathrm{e}^{+} \mathrm{e}^{-}$. This process requires a photon energy larger than about $1 \mathrm{MeV}$ (twice the electron rest mass), and cannot take place in vacuum. To guarantee the conservation of linear momentum, the photon must interact with an external field (nuclear or electronic). The two interactions possible below $1 \mathrm{MeV}$, photoelectric absorption and scattering, give origin to three basic groups of experimental techniques: spectroscopy, elastic scattering, and imaging.

For XAS, the energies are from about $1 \mathrm{keV}$ to about $100 \mathrm{keV}$ corresponding to wavelengths from about 0.12 to about $12 \AA$, respectively. In this energy range, the dominant attenuation mechanism is photoelectric absorption. XAS gives mainly information on the electronic structure of the matter. In this energy range the behavior of the photo-electric absorption coefficient is very simple and qualitatively very similar for different atomic species. When the energy of the absorbed X-ray photons increases, the absorption coefficient progressively decreases (harder X-rays are more penetrating). The absorption also depends on the atomic species, the heavier the atom, the more absorbent they are. The smooth energy dependence of the phot-electric absorption is interrupted by sharp discontinuities, the absorption edges. At this point the bonding energy of an inner electron is reached. The energy belonging to the edge is the so-called threshold energy. Beyond this energy a fine structure in the spectrum is seen up to even $10000 \mathrm{eV}$

The XAS spectrum has different areas (Figure 9) providing different information. The part of the spectrum before the absorption edge is the pre-edge region. From here information can be gained on the bonding character, the oxidation state and the coordination geometry of the element studied. 


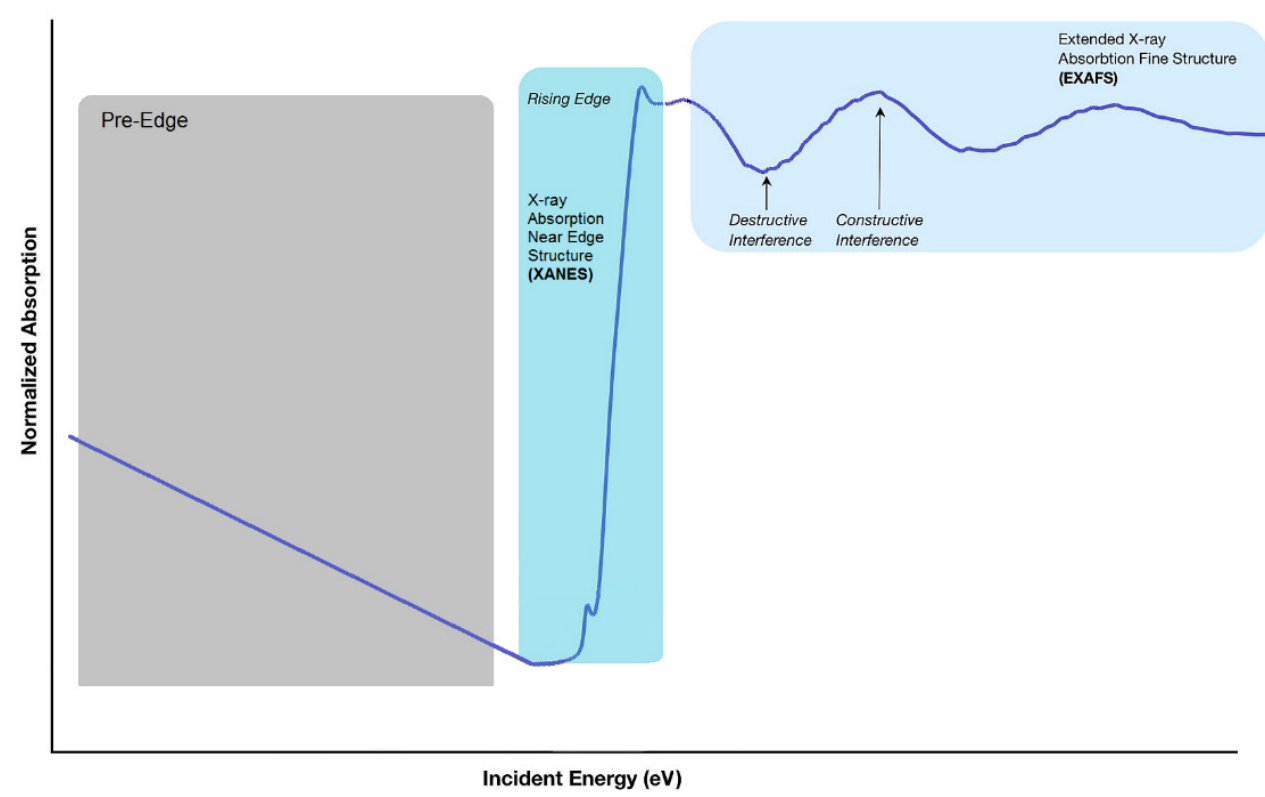

Figure 9. Various regions of the X-ray absorption spectrum (XANES - X-ray Absorption Near Edge Structure, EXAFS - Extended X-ray Absorption Fine Structure)

The pre-edge region is followed by the absorption edge and its immediate surroundings, this is the XANES region. From the XANES region, information can be obtained on the local electronic as well as geometric structure of the sample. For this region an also acceptable term is near edge X-ray Absorption Fine Structure (NEXAFS). XANES and NEXAFS are synonyms, although NEXAFS by convention is usually reserved for soft X-ray spectroscopy, where the photon energy is less than $1000 \mathrm{eV}$. NEXAFS is generally used in surface and molecular sciences, while XANES is used in most other fields. Changes in this region may serve as a fingerprint for the materials. The near edge region is the most sensitive to the changes in the geometry around the absorber atom or ion, exhibiting significant spectral changes. These are mainly due to the scattering of photoelectrons with low kinetic energies.

The next region of the XAS spectrum is the extended X-ray Absorption Fine Structure (EXAFS). This region extends from the XANES region to up to typically 1000 eV. EXAFS carries information on the local geometric structure surrounding a given atomic species. When an X-ray photon of high enough energy is absorbed by an atom, a core electron is ejected from the atom (ionization process). The outgoing photoelectron is described by a wave-function, approximated by a spherical wave whose wavelength decreases when the photon energy increases (Figure 10). If the absorber atom is not isolated, the photo-electron can be backscattered by neighboring atoms, giving rise to an incoming spherical wave. The phase relationship between outgoing and incoming waves 
depends on photo-electron wavelength and inter-atomic distance R. The final photoelectron stationary state is thus the superposition of the outgoing spherical wave and the incoming back-scattered wave. The variation of phase relationship as a function of photon energy influences the final state amplitude at the core site, giving rise to an interference phenomenon, which modulates the absorption coefficient. The frequency of EXAFS oscillations depends on the distance between absorber and backscatterer atoms. Their amplitude is proportional to the number of backscatterer atoms ${ }^{[150]}$.
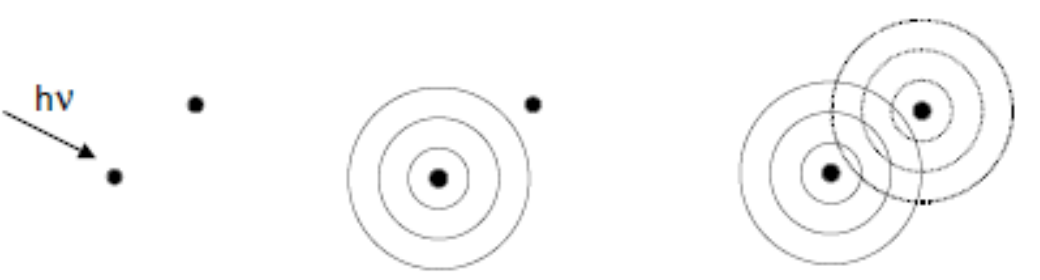

Figure 10. Schematic explanation of the EXAFS phenomenon: X-ray photon absorption (left), emission of photoelectron spherical wave (center), backscattering of the photoelectron by neighboring atoms ${ }^{[150]}$

The basic information that can be obtained from the analysis of the EXAFS spectra concerns a few coordination shells surrounding the absorbing atom (typically within about $10 \AA$ ). For each coordination shell the average inter-atomic distance (r), the coordination number $(\mathrm{N})$ and the Debye-Waller parameter can be obtained. The DebyeWaller parameter $\left(\sigma^{2}\right)$ measures the degree of thermal and structural disorder. These properties, along with the relative easiness of measurement, data analysis and interpretation, make EXAFS a very appealing method for determining the local structure. This method is most frequently used in the determination of the local structure in noncrystalline materials, for the determination of the local environment in of the atoms in heterogeneous matrices, for systems with local properties different from average properties, and for the determination of the dynamics in crystalline solids. 


\section{RESULTS AND DISCUSSION}

\subsection{Preparation of Sn(IV)-containing LDHs}

In the literature there is a controversy surrounding Sn(IV)-containing LDHs (see, Ch. 2.2). For achieving the goal, to synthesize Ca(II)Sn(IV)-LDHs, two preparation methods (co-precipitation and mechanochemistry) were tried. Samples prepared by the first method, their acronyms, molar ratios and synthesis parameters, are presented in Table 2.

Table 2. Samples prepared with the co-precipitation method

\begin{tabular}{ccccc}
\hline $\begin{array}{c}\text { Sample } \\
\text { acronyms }\end{array}$ & $\begin{array}{c}\mathrm{Ca}(\mathrm{II}): \mathrm{Sn}(\mathrm{IV}) \\
\text { molar ratios }\end{array}$ & $\begin{array}{c}\mathrm{c}\left(\mathrm{Ca}(\mathrm{II}) \mathrm{Cl}_{2}\right) \\
(\mathrm{mol} / \mathrm{L})\end{array}$ & $\begin{array}{c}\mathrm{c}\left(\mathrm{SnCl}_{4}\right) \\
(\mathrm{mol} / \mathrm{L})\end{array}$ & $\mathrm{pH}$ \\
\hline $\mathrm{Ca} 3 \mathrm{Sn}$ & $3: 1$ & 0.12 & 0.04 & \\
$\mathrm{Ca}_{4} \mathrm{Sn}$ & $4: 1$ & 0.16 & 0.04 & 9 \\
$\mathrm{Ca}_{5} \mathrm{Sn}$ & $5: 1$ & 0.20 & 0.04 & \\
$\mathrm{Ca}_{6} \mathrm{Sn}$ & $6: 1$ & 0.24 & 0.04 & \\
\hline
\end{tabular}

The X-ray diffractograms of these samples are presented without baseline correction or smoothing, in Figure 11. The typical diffractogram of an LDH displays three major reflections (usually indexed as (003), (006), (009)), from which the (003) is the most significant - it appears around $10^{\circ} 2 \theta$ value. The presence or lack of these reflections was investigated, to determine, whether the LDH formation was successful or not.

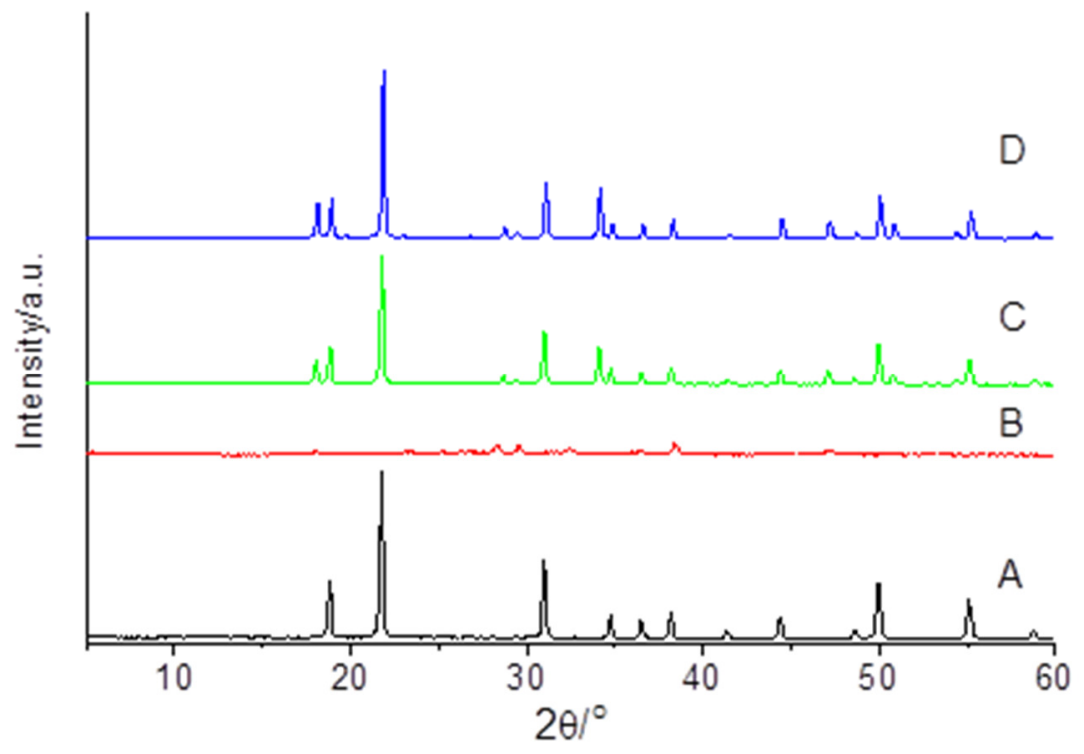

Figure 11. Powder X-ray diffractograms of Ca(II)Sn(IV) samples prepared by the co-precipitation method: (A) $\mathrm{Ca}_{3} \mathrm{Sn},(\mathrm{B}) \mathrm{Ca}_{4} \mathrm{Sn},(\mathrm{C}) \mathrm{Ca}_{5} \mathrm{Sn},(\mathrm{D}) \mathrm{Ca}_{6} \mathrm{Sn}$ 
The diffractograms of the Ca(II)Sn(IV) samples do not exhibit increase in the baseline, i.e., the crystallinity is good. Although the Ca:Sn molar ratios were varied in a wide range, in neither case could the specific reflections of the LDHs be recognized. In order to identify the reflections, the analysis of a randomly chosen diffractogram (Figure 12) is given.

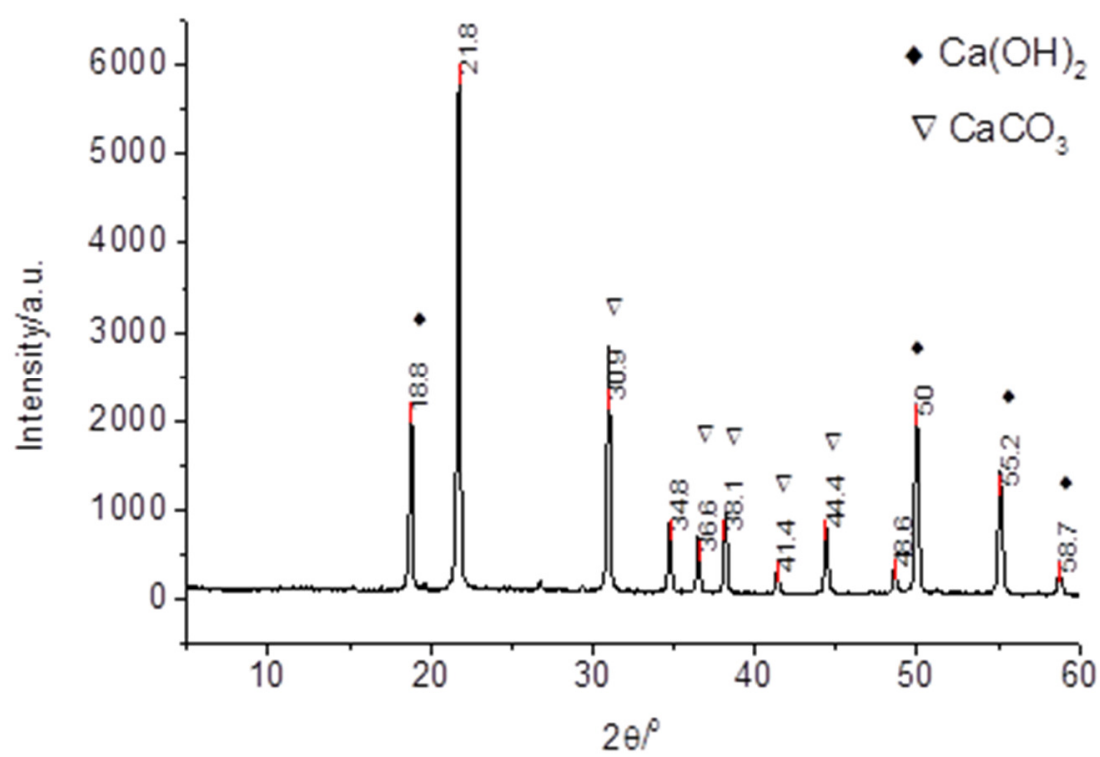

Figure 12. Powder X-ray diffractogram of the $\mathrm{Ca}_{3} \mathrm{Sn}$ sample prepared by the co-precipitation method, with its typical reflections: black diamond $-\mathrm{Ca}(\mathrm{OH})_{2}$, black and white triangle $-\mathrm{CaCO}_{3}$

The typical reflections of $\mathrm{Ca}(\mathrm{OH})_{2}$ and $\mathrm{CaCO}_{3}$ could be identified $\left(\mathrm{CO}_{2}\right.$ is most probably airborne). This proves that $\mathrm{Ca}(\mathrm{OH})_{2}$ was precipitated, but the incorporation of the Sn(IV) ions into its layers did not happen. The presence of $\mathrm{CaCO}_{3}$ is due to the fact that during the synthesis, air was not excluded. It can be concluded that using the coprecipitation method, Ca(II)Sn(IV)-LDHs could not be synthesized. It is worth mentioning that our attempt for the preparation of Co(II)Sn(IV)-LDH (Co(II)/Sn(IV) = 3) by the co-precipitation method was also unsuccessful, in spite of ageing the freshly precipitated material for 6 hours at $343 \mathrm{~K}$.

After these experiments, we gave up using the solution-phase chemical method and turned to mechanochemistry. Samples prepared using the various mechanochemical and mechanochemically-assisted methods, with their designations, molar ratios and synthesis parameters, are presented in Table 3. 
Table 3. Samples prepared with the mechanochemically-assisted methods: using mixer mill with dry (mm_d) and wet (mm_w) milling and using agate mortar with dry (m_d) and wet (m_w) grinding

\begin{tabular}{cccccc}
\hline Sample & $\mathrm{Ca}(\mathrm{II}): \mathrm{Sn}(\mathrm{IV})$ & $\begin{array}{c}\text { Frequency } \\
(\mathrm{Hz})\end{array}$ & $\begin{array}{c}\text { Added } \mathrm{H}_{2} \mathrm{O} \\
(\mathrm{mL})\end{array}$ & $\begin{array}{c}\text { Dry milling } \\
(\mathrm{h})\end{array}$ & $\begin{array}{c}\text { Wet milling } \\
(\mathrm{h})\end{array}$ \\
\hline Ca4Sn_mm_d & $4: 1$ & 11.6 & 0 & 3 & 0 \\
Ca4Sn_mm_w & $4: 1$ & & 0.7 & 1 & 2 \\
\hline \hline Ca4Sn_m_d & $4: 1$ & - & 0 & $\mathrm{Na}$ & $\mathrm{Na}$ \\
Ca4Sn_m_w & $4: 1$ & & 0.35 & $\mathrm{Na}$ & $\mathrm{Na}$ \\
\hline
\end{tabular}

The XRD results for the Ca(II)Sn(IV) samples synthesized via the pure mechanochemical (dry or one-step milling) and the mechanochemically-assisted (dry plus wet or two-step milling and wet grinding) are presented in Figure 13.

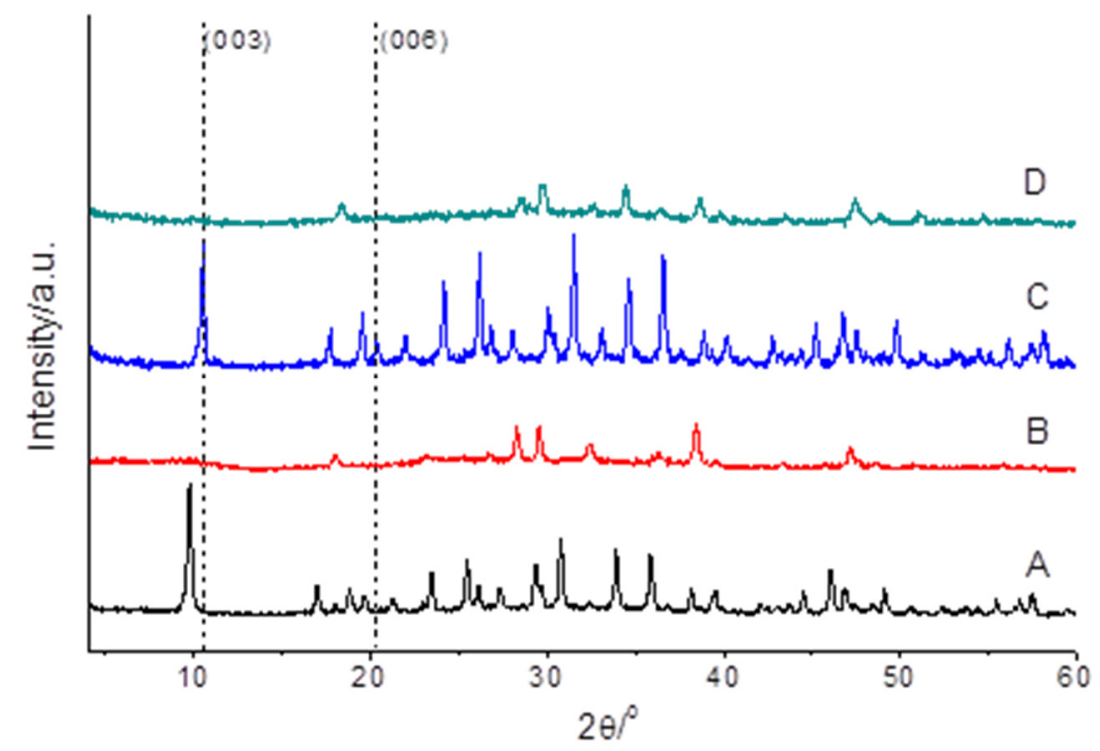

Figure 13. Powder X-ray diffractogram of $\mathrm{Ca}(\mathrm{II}) \operatorname{Sn}(\mathrm{IV})$ samples prepared via mechanochemical methods (A) $\mathrm{Ca}_{4} \mathrm{Sn}_{-} \mathrm{mm}_{-} w$, (B) $\mathrm{Ca}_{4} \mathrm{Sn}_{-} \mathrm{mm}_{-} \mathrm{d}$, (C) Ca4 $\mathrm{Sn}_{-} \mathrm{m}_{-}$w, (D) $\mathrm{Ca} 4 \mathrm{Sn}_{-} \mathrm{m}_{-} \mathrm{d}$

In the one-step milling operations (curves B and D), there were no LDH formation; the specific reflections of the LDH are missing. However, in the two-step milling operations (traces $\mathrm{A}$ and $\mathrm{C}$ ) at $10^{\circ} 2 \theta$ values, the (003) reflection specific to $\mathrm{LDH}$ structure appeared. Thus, it is strongly indicated that the two-step milling method produced Ca(II)Sn(IV)-LDH. The observation that the synthesis was only successful in the two-step milling procedure is due to the fact that using only dry milling the crystal water introduced with the precursors could not generate sufficient amounts of hydroxide group necessary for the LDH structure. Using the Bragg equation, the interlayer spacing of the LDHs could be calculated from the positions of the (003) reflections, and they were $8.38 \AA$ and $9.05 \AA$ for the Ca4Sn_mm_w and Ca4Sn_m_w samples, respectively. 
To provide further proof of LDH formation, SEM measurements were performed in order to gain information about the morphologies of the samples. The hexagonallyshaped lamellar structure, the typical morphology of LDHs was sought. As Figure 14 and Figure 15 attest, the SEM images of Ca(II)Sn(IV) samples prepared with two-step milling or the wet grinding methods show these characteristics.

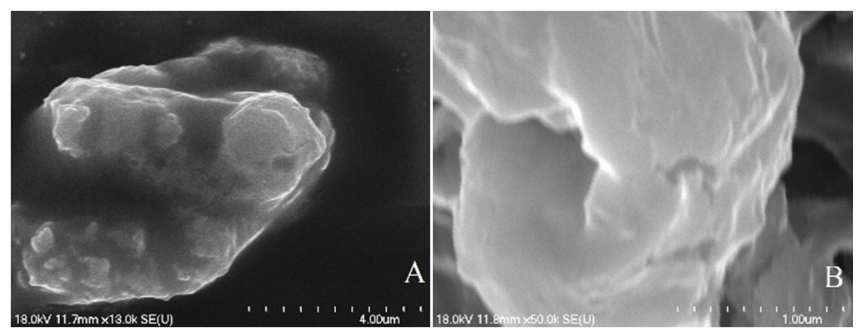

Figure 14. SEM images of the $\mathrm{Ca}_{4} \mathrm{Sn}_{-} \mathrm{mm}_{-}$w samples at magnifications of 13,000 (A), and 50,000 (B)

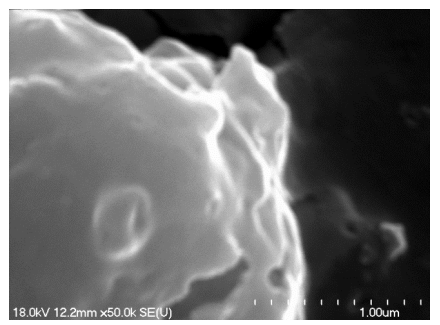

Figure 15. SEM image of the Ca4Sn_m_w sample at a magnification of 50,000

The particle sizes are larger than what one would expect for LDHs; however, it may be assumed that the amorphous phase is due to smaller particles sticking together to form bigger aggregates. The SEM images have confirmed the results of the XRD measurements: substances with LDH-like morphologies were formed indeed, but only in the two-step mechanochemically-assisted syntheses.

Using EDX, the elemental composition could be obtained and projecting it on the corresponding SEM image, the elemental map, and thus, the elemental distribution of the samples could be visualized. For the $\mathrm{Ca}_{4} \mathrm{Sn}_{-} \mathrm{mm}_{-} \mathrm{w}$ sample, the elemental analysis was performed, from which it could be concluded that during the preparation of the samples iron contamination (iron was the main component of the grinding balls and grinding jars) did not occur. On the elemental map of both the Ca4Sn_mm_w and $\mathrm{Ca}_{4} \mathrm{Sn}_{-} \mathrm{m}_{-} \mathrm{w}$ samples (Figure 16 andFigure 17 ), it can be observed that the distributions of the Ca and Sn are uniform within the particles, no aggregation or segregation can be noticed. This is also another piece of evidence supporting that LDH was formed during the two-step milling as well as the wet grinding procedures. 


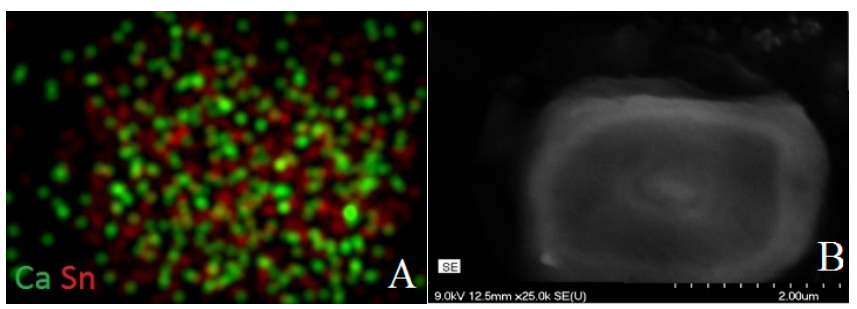

Figure 16. Elemental distribution map (A) on the Ca4Sn_mm_w sample (B)

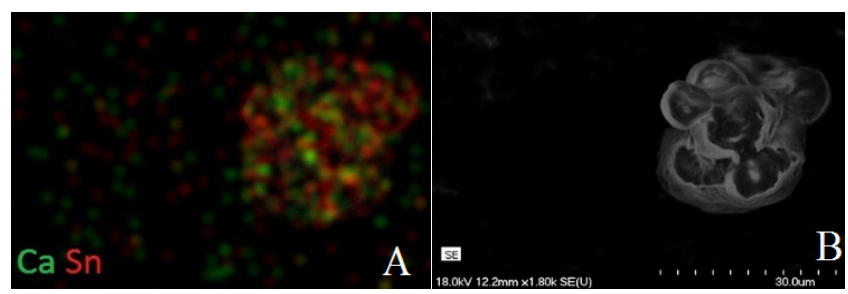

Figure 17. Elemental distribution map (A) on the Ca4Sn_m_w sample (B)

From these results, it is clear that the combination of dry and wet milling is a viable choice in the preparation of $\mathrm{Ca}(\mathrm{II}) \mathrm{Sn}(\mathrm{IV})$-containing LDHs, which cannot be easily approached, if at all, by solution-phase methods.

\subsection{Preparation of pristine Ca(II)Al(III)- and Ca(II)Fe(III)-LDHs}

The preparation of $\mathrm{Ca}(\mathrm{II}) \mathrm{Sn}(\mathrm{IV})-\mathrm{LDHs}$ proved that mechanochemistry was a feasible option in the syntheses of LDHs. This method was set to be enhanced, by optimizing the reaction parameters of the synthesis of both the Ca(II)Al(III)- and Ca(II)Fe(III)-LDHs. The first mechanochemical method used for the Ca(II)Al(III) system, was the two-step grinding procedure performed in an agate mortar.

On preparing the pristine LDH, several experiments were performed in order to determine the optimal Al: $\mathrm{NaOH}$ molar ratio for the synthesis. These samples with their acronyms, and molar ratios are presented in Table 4.

Table 4. Pristine CaAl-LDH samples

\begin{tabular}{ccccc}
\hline $\begin{array}{c}\text { Sample } \\
\text { acronyms }\end{array}$ & $\begin{array}{c}\mathrm{Ca}(\mathrm{II}): \mathrm{Al}(\mathrm{III}) \\
\text { molar ratios }\end{array}$ & $\begin{array}{c}\mathrm{Al}(\mathrm{III}): \mathrm{NaOH} \\
\text { molar ratios }\end{array}$ & $\begin{array}{c}\text { Added 3M NaOH } \\
{[\mu \mathrm{l}]}\end{array}$ & $\begin{array}{c}\text { Added } \\
\mathrm{H}_{2} \mathrm{O}[\mu \mathrm{l}]\end{array}$ \\
\hline $\mathrm{Ca} 2 \mathrm{Al}$-7 & & $7: 1$ & 100 & \\
$\mathrm{Ca} 2 \mathrm{Al} \_2.33$ & & $2.33: 1$ & 300 & \\
$\mathrm{Ca} 2 \mathrm{Al} \_1.16$ & $2: 1$ & $1.16: 1$ & 600 & - \\
$\mathrm{Ca} 2 \mathrm{Al} 1$ & & $1: 1$ & 700 & \\
$\mathrm{Ca} 2 \mathrm{Al}$ 0.87 & & $0.87: 1$ & 800 & \\
$\mathrm{Ca} 2 \mathrm{Al} \_\mathrm{H}_{2} \mathrm{O}$ & & - & - & 100 \\
\hline
\end{tabular}


The X-ray diffractograms of the samples (after base-line correction) are presented in Figure 18. The typical diffractogram of an LDH displays three major reflections, from which the most significant appears around $2 \theta=10^{\circ}$ value. The presence or lack of these reflections was investigated, to determine, whether or not LDH formation occurred.

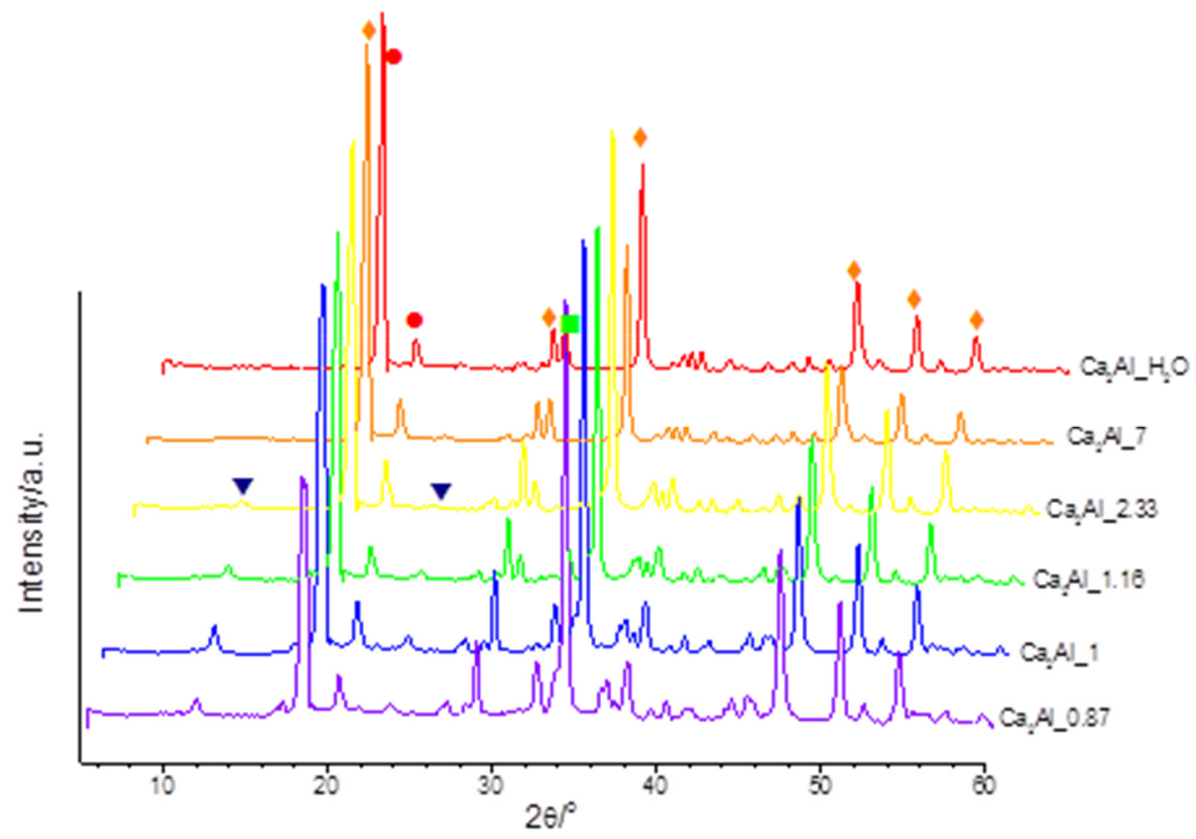

Figure 18. Powder X-ray diffractograms of the pristine co-grinded samples, with the specific reflections of their components: orange diamond $-\mathrm{Ca}(\mathrm{OH})_{2}$; red dot $-\mathrm{Al}(\mathrm{OH})_{3}$; green square $-\mathrm{CaCO}_{3}$; blue triangle - LDH.

It is clear from the lack of the specific reflections of the LDHs in Figure 18 that on adding small amount of water/base only, no LDH formation was experienced. It is also revealed that the presence of the base was necessary for the LDHs to form. The optimal $\mathrm{Al}: \mathrm{NaOH}$ ratio was found to be $1: 1$. In this case, the typical reflections of the LDHs had the highest intensities, and the lowest FWHM (full width at half maximum) values shown in Table 5.

Table 5. FWHM values of the pristine CaAl-LDH samples prepared using a mortar

\begin{tabular}{cc}
\hline Sample & $\begin{array}{c}\text { FWHM of the LDHs 001 } \\
\text { reflection }\left({ }^{\circ}\right)\end{array}$ \\
\hline $\mathrm{Ca}_{2} \mathrm{Al}_{-} \mathrm{H}_{2} \mathrm{O}$ & - \\
$\mathrm{Ca} 2 \mathrm{Al}$-7 & - \\
$\mathrm{Ca} 2 \mathrm{Al} \_2.33$ & 2.46 \\
$\mathrm{Ca} 2 \mathrm{Al} \_1.16$ & 0.66 \\
$\mathrm{Ca} 2 \mathrm{Al} \_1$ & 0.41 \\
$\mathrm{Ca} 2 \mathrm{Al} 0.87$ & 1.17 \\
\hline
\end{tabular}


Although LDH formation could be observed in four of the samples, it was clear that it was far from being complete. A typical diffractogram, presented in Figure 19, shows the reflections of the following phases: $\mathrm{Ca}(\mathrm{OH})_{2}$ (JCPDS \#76-0570), $\mathrm{Al}(\mathrm{OH})_{3}$ (JCPDS \#702038), $\mathrm{Na}_{2} \mathrm{CO}_{3}$ (JCPDS \#70-0845) and Ca2Al-LDH (JCPDS\#41-0219). Justification for correctly choosing this latter card will be given later, and indexing the diffractogram on this basis will be shown on the diffractogram of the LDH prepared under the optimized conditions.

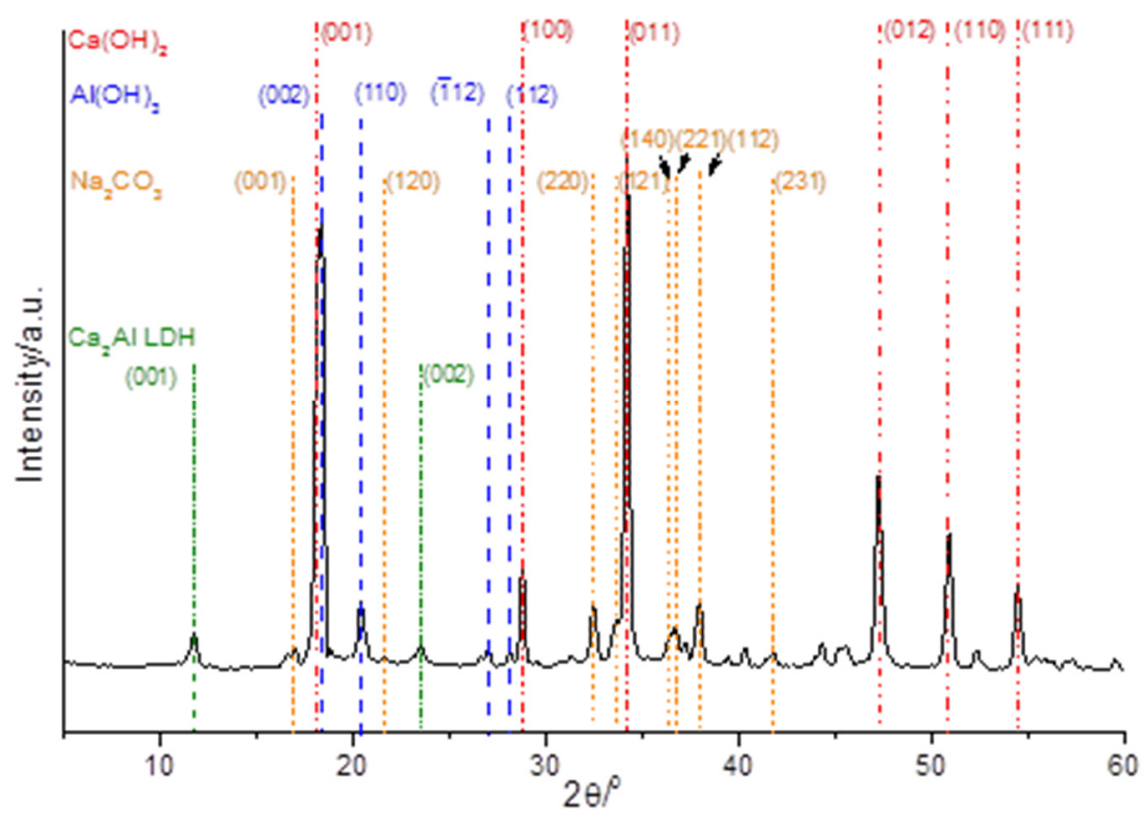

Figure 19. Powder X-ray diffractograms of the pristine $\mathrm{Ca}_{2} \mathrm{Al}_{-} 1$ co-grinded samples, with the specific reflections of their components

In Figure 18, the typical reflections of the unreacted precursors predominate. These observations highlight the fact that LDH could be prepared under these conditions, but the transmitted mechanical energy was not sufficient for the complete transformation of the reactants to CaAl-LDH.

In order to obtain LDH with better phase-purity, it is necessary to upscale the transmitted mechanical energy. For this, a two-step mechanochemical synthesis was carried out using a mixer mill. The X-ray diffractogram of the sample prepared this way, without any optimization, is presented in Figure 20. The total weight of the sample was $3 \mathrm{~g}$, giving the ball/sample weight ratio (hereafter $\mathrm{B} / \mathrm{S}$ ) of 18 . The diffractogram resembles those of the samples prepared with manual grinding: the presence of the LDH is obvious, but the unreacted precursors still represent the major phases. It was clear that increasing the conversion to LDH required the optimization of the parameters of 
the synthesis: the amount of the added water, the ball/sample weight ratio as well as the grinding frequency.

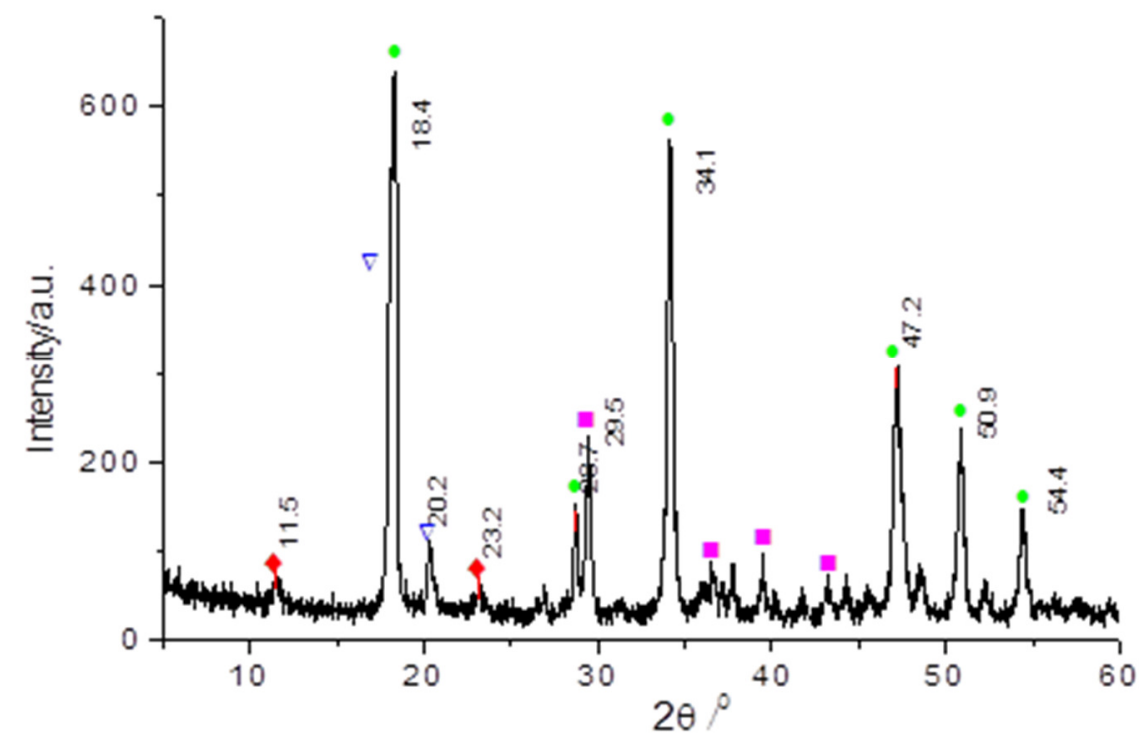

Figure 20. Powder X-ray diffractogram of the pristine milled sample $\left(B / S=18, n\left(\mathrm{H}_{2} \mathrm{O}\right): \mathrm{n}(\mathrm{Al})=1.25\right.$, $v=11.6 \mathrm{~Hz}$ ), with the specific reflections of its components: green dot $-\mathrm{Ca}(\mathrm{OH})_{2}$; blue triangle $-\mathrm{Al}(\mathrm{OH})_{3}$; purple square - $\mathrm{CaCO}_{3}$ (JCPDS \#47-1743); red diamond - $\mathrm{LDH}$

The first parameter to be optimized was the amount of added water at B/S ratio of 18 and $11.6 \mathrm{~Hz}$ grinding frequencies. The diffractograms registered are displayed in Figure 21.

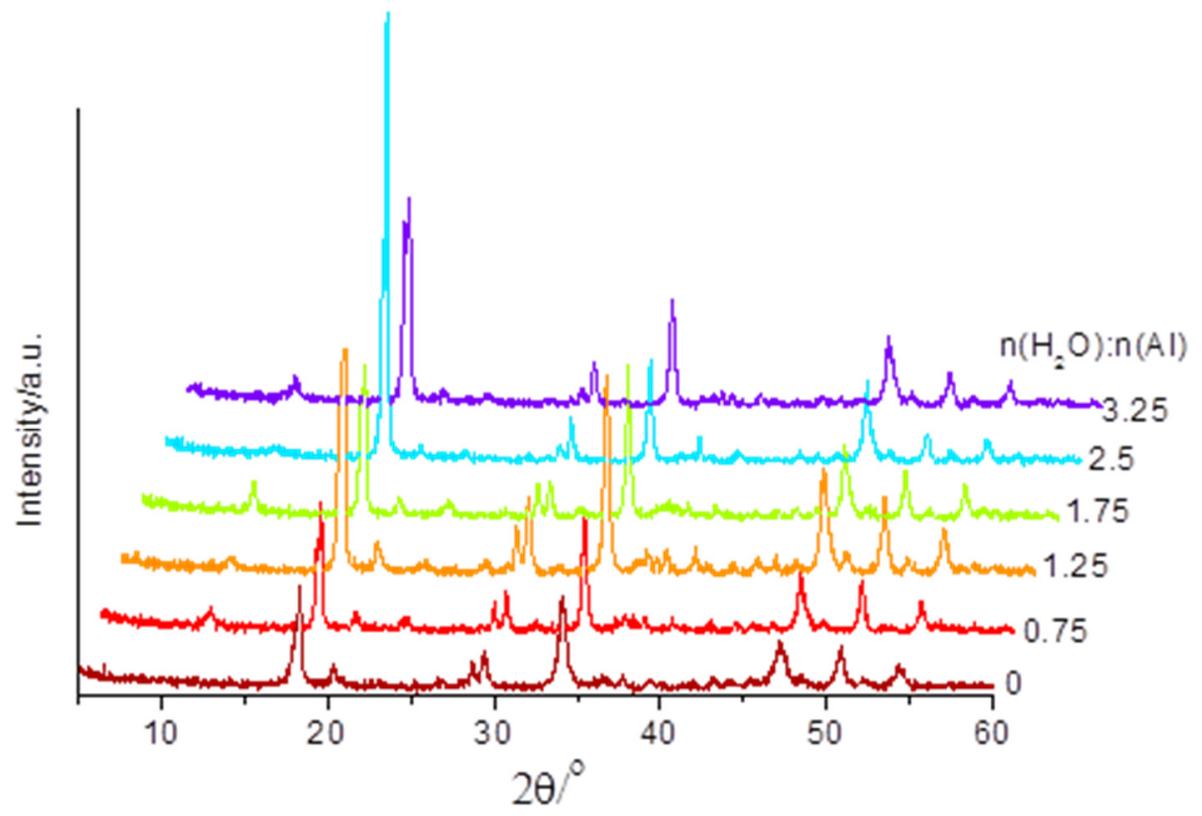

Figure 21. X-ray diffractograms of the milled samples $(B / S=18, v=11.6 \mathrm{~Hz})$, after the systematic changes in the $\mathrm{H}_{2} \mathrm{O}: \mathrm{Al}$ molar ratio 
The diffractograms reveal that without any added water, LDH was not formed the reflections of the LDH could not be identified. The explanation for this is that although the precursors were metal hydroxides, additional hydroxide groups were needed for the LDH to form, and they were provided by the added water. It is also known that in the structure of the LDH, three types of water are present: physisorbed, interlayer and structural water. As soon as water was present in the system, formation of LDH could be noticed. Increasing the amount of the added water, the FWHM values of the LDH reflections decreased to a point (see, Table 6), then, increased again. The optimum value for the $\mathrm{H}_{2} \mathrm{O}: \mathrm{Al}$ ratio was found to be 1.75 . The relevant reflections were sharp, and the relative intensities of the LDH were the highest compared to those of the unreacted precursors. In further optimizations, this $\mathrm{H}_{2} \mathrm{O}$ : Al ratio was used.

Table 6. FWHM values of the pristine CaAl-LDH samples prepared using a mixer mill after the systematic changes in the $\mathrm{H}_{2} \mathrm{O}: \mathrm{Al}$ molar ratio

\begin{tabular}{cc}
\hline$n\left(\mathrm{H}_{2} \mathrm{O}\right): n(\mathrm{Al})$ & $\begin{array}{c}\text { FWHM of the 001 reflections } \\
\text { of the LDH samples }\left({ }^{\circ}\right)\end{array}$ \\
\hline 3.25 & 1.41 \\
2.50 & 2.23 \\
1.75 & 0.62 \\
1.25 & 1.08 \\
0.75 & 0.94 \\
0 & - \\
\hline
\end{tabular}

To increase the mechanical energy, the $\mathrm{B} / \mathrm{S}$ ratio had to be increased. In order to do it, given that a single grinding ball per grinding jar was only available, the weight of the samples had to be reduced. Then, at $\mathrm{H}_{2} \mathrm{O}: \mathrm{Al}=1.75$ molar ratio and $11.6 \mathrm{~Hz}$ grinding frequency, the B/S ratio was altered from 25 to 140, and the diffractograms obtained are presented in Figure 22. It seems to be evident that upon increasing the B/S ratio, the intensities of the reflections corresponding to the unreacted precursors decreased, and above $B / S=100$, the reflections of the $\mathrm{LDH}$ were predominantly present in the system, i.e., a near phase-pure LDH was formed under these circumstances. Thus, it can be stated that at $\mathrm{B} / \mathrm{S}=100$, the amount of mechanical energy per unit became sufficient for the chemical reaction to take place between the precursors. In further syntheses, the B/S ratio of 140 was applied. 


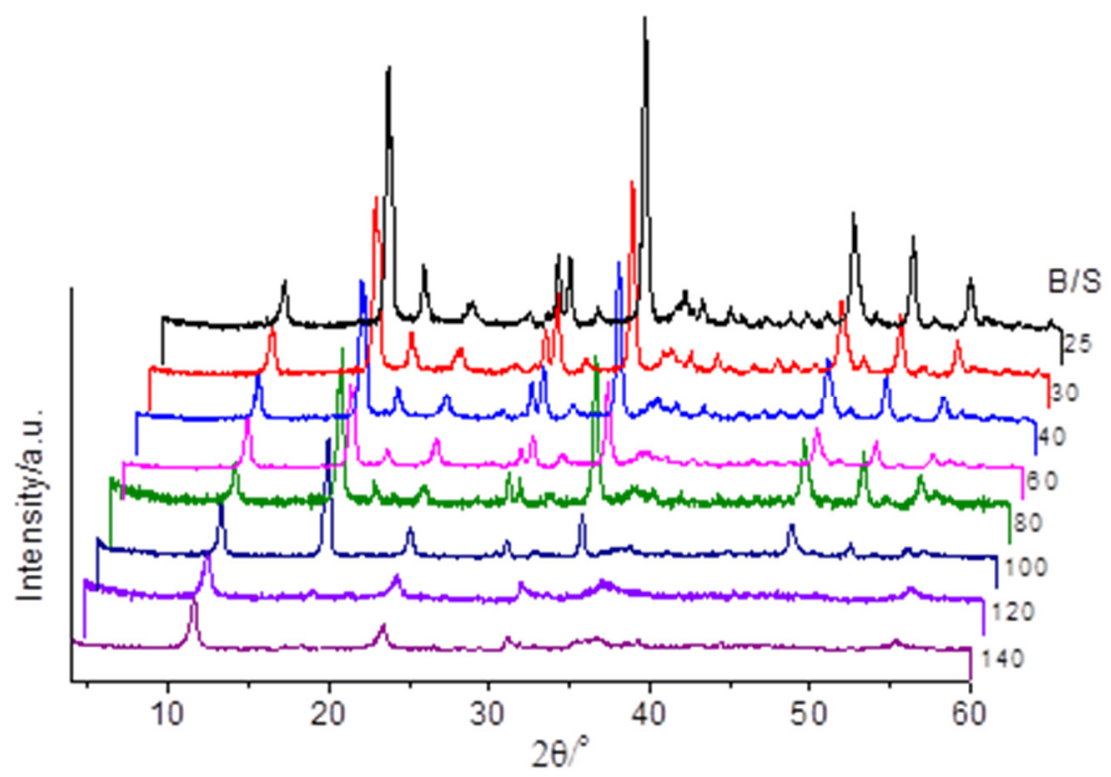

Figure 22. X-ray diffractograms of the milled samples $\left(n\left(\mathrm{H}_{2} \mathrm{O}\right): n(\mathrm{Al})=1.75, v=11.6 \mathrm{~Hz}\right)$, with the systematic change of the $\mathrm{B} / \mathrm{S}$ weight ratio

The following parameter to be varied was the grinding frequency. This was altered in a wide range, from $9.6 \mathrm{~Hz}$ to $13.6 \mathrm{~Hz}$ (Figure 23).

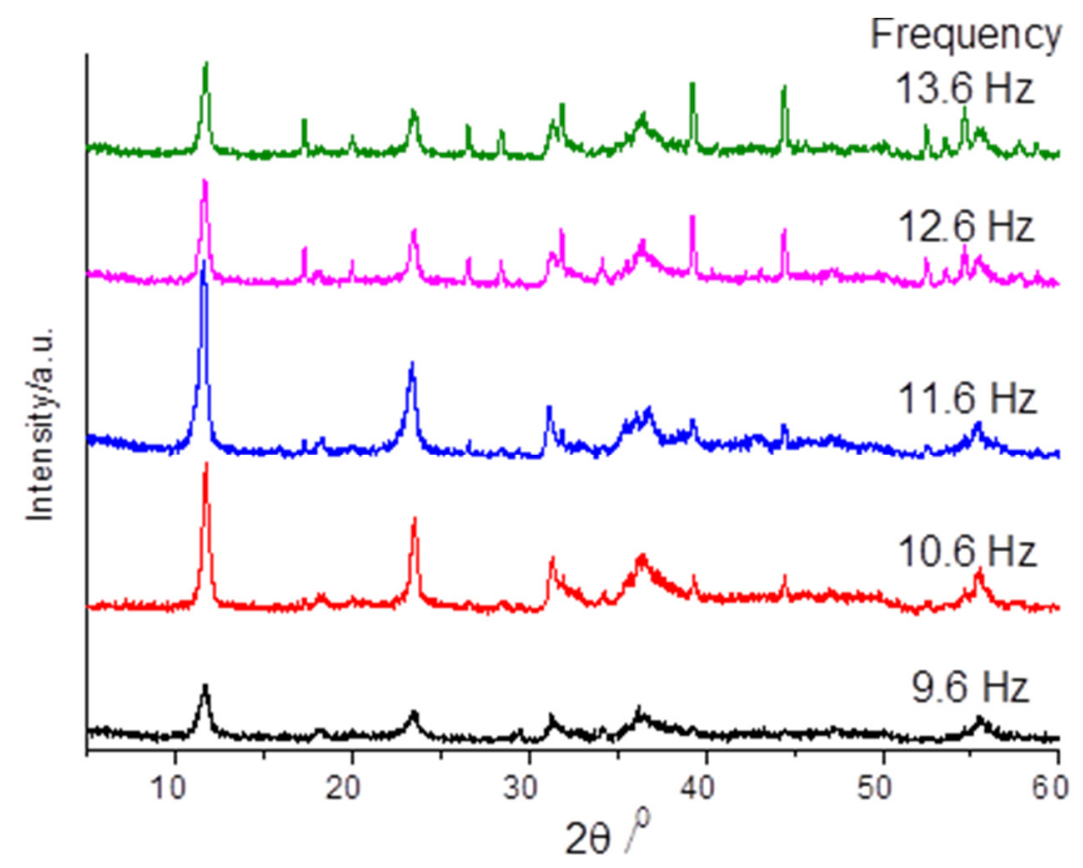

Figure 23. X-ray diffractograms of the milled samples $\left(n\left(\mathrm{H}_{2} \mathrm{O}\right): n(\mathrm{Al})=1.75, \mathrm{~B} / \mathrm{S}=140\right)$, with the systematic change of the grinding frequency

The effect of the grinding frequency seems to have a more complex effect on the LDHs than expected. At lower grinding frequencies, the intensities of the reflections were smaller, reaching their maximum values at $11.6 \mathrm{~Hz}$. At this frequency, the 
reflections were the sharpest as well. Further increase in the grinding frequency resulted in the gradual loss of intensities (Table 7).

Table 7. FWHM values of the pristine CaAl-LDH samples prepared using a mixer mill, after the systematic changes of the grinding frequency

\begin{tabular}{cc}
\hline$v(\mathrm{~Hz})$ & $\begin{array}{r}\text { FWHM of the 001 reflections } \\
\text { of the LDHs }\left(^{\circ}\right)\end{array}$ \\
\hline 13.6 & 0.41 \\
12.6 & 0.45 \\
11.6 & 0.36 \\
10.6 & 0.42 \\
9.6 & 0.79
\end{tabular}

Wang et al. ${ }^{[151]}$ studied the effect of the mechanochemical treatment on the already synthesized LDHs, and they found that due to the mechanical treatment, the crystallinity of the samples decreased with the milling time until the total destruction of the solid crystal structure. This finding explains our observation; therefore, in our experimental set-up, $11.6 \mathrm{~Hz}$ grinding frequency was the optimum for the LDH synthesis.

The optimized parameters for the synthesis of CaAl-LDH in a mixer mill were as follows: $\mathrm{B} / \mathrm{S}=140, \mathrm{n}\left(\mathrm{H}_{2} \mathrm{O}\right): \mathrm{n}(\mathrm{Al})=1,75$ and $v=11.6 \mathrm{~Hz}$. The XRD of the sample prepared under these conditions is presented in Figure 24, after baseline correction.

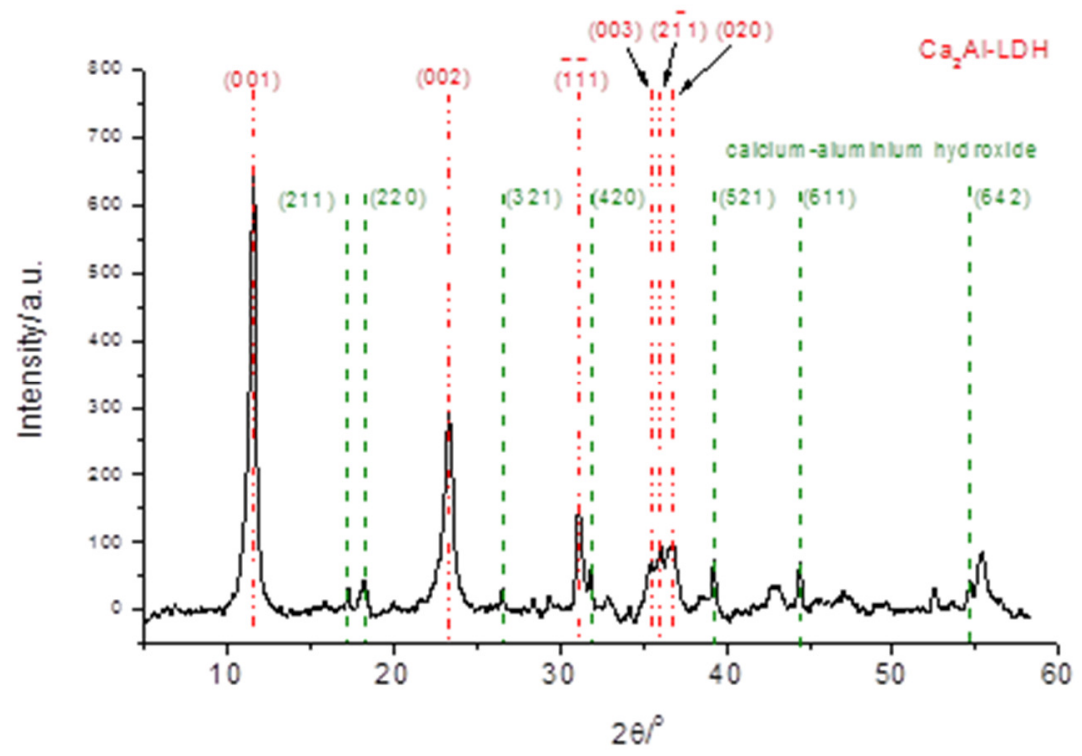

Figure 24. X-ray diffractogram of the optimised milled sample $\left(n\left(\mathrm{H}_{2} \mathrm{O}\right): n(\mathrm{Al})=1.75, \mathrm{~B} / \mathrm{S}=140\right.$, $v=11.6 \mathrm{~Hz}$ ), with their specific reflections: red dash-dot - Ca2Al-LDH (JCPDS \#41-0219), green dash calcium aluminium hydroxide (JCPDS \#74-2281)

The chemical composition of the material corresponding to JCPDS\#41-0219 is $\mathrm{Ca}_{4} \mathrm{Al}_{2} \mathrm{O}_{6} \mathrm{CO}_{3} \cdot 11 \mathrm{H}_{2} \mathrm{O}$, and this material was described as layered double hydroxide 
(Renaudin et al.[152]). The diffractogram shows that the only impurity in the system was a small amount of calcium aluminium hydroxide (15.6 wt.\%), which is known in the aluminium industry as tricalcium aluminate (TCA), thus, the LDH content was $84.4 \mathrm{wt} . \%$. The wt.\% distribution of the phases was calculated by measuring the integrated intensity of the most intense peak in each phase, and then, using the reference intensity ratio as a scaling factor, which converts the intensities to weight percent[153].

Our sample contained carbonate as the major charge-balancing anion verified by the carbonate vibration in the FT-IR spectrum of the sample (Figure 25).

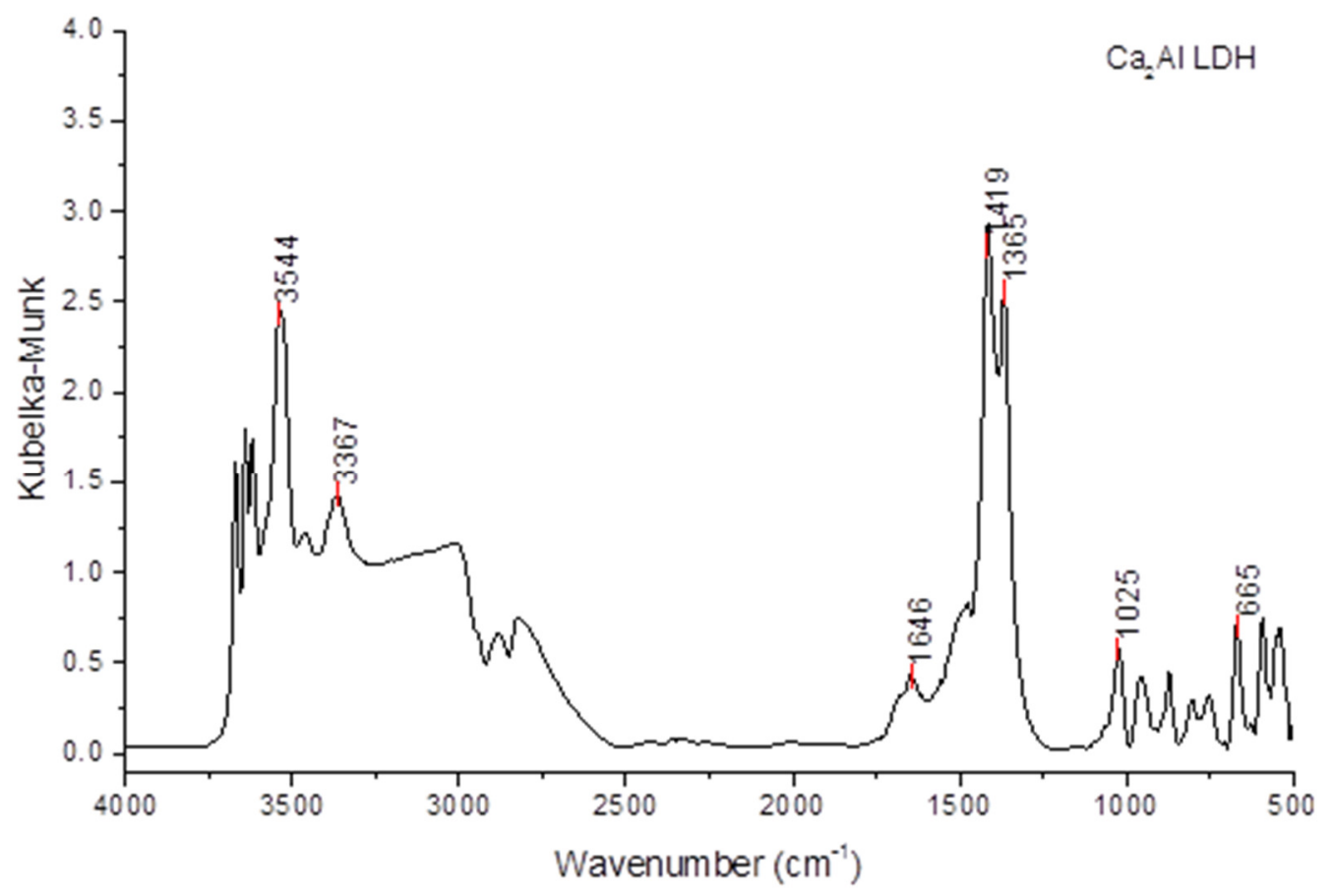

Figure 25. FT-IR spectrum of the Ca2Al-LDH prepared under the optimized conditions (see the vibration $1365 \mathrm{~cm}^{-1}$, typical of interlayer carbonate ion)

On the SEM images of the CaAl-LDH sample prepared under optimal conditions (Figure 26) the typical lamellar LDH morphology can be observed.

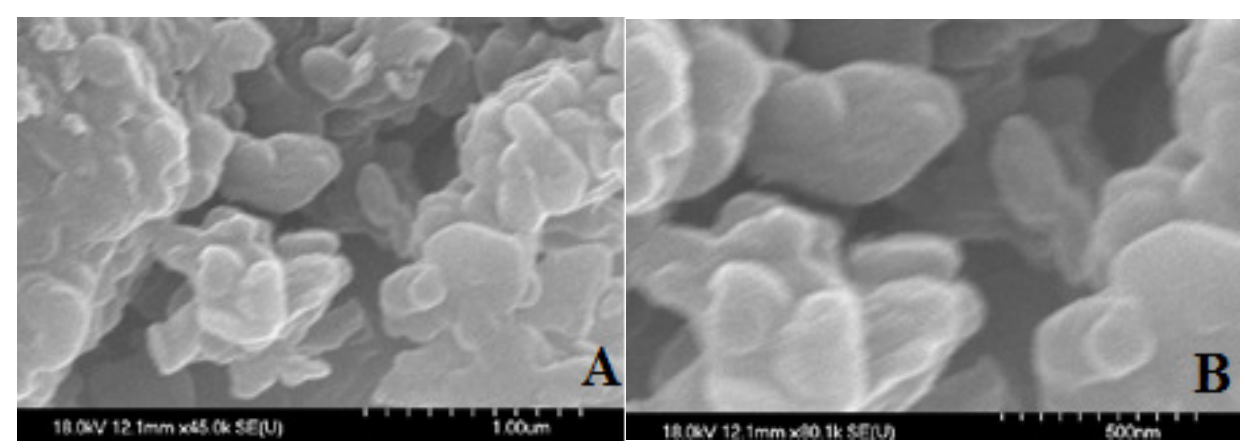

Figure 26. SEM images of the optimized CaAl-LDH sample at various magnifications (A - 45,000, B - 80,000) 
To sum up, the mechanochemical methods led to the formation of CaAl-LDHs, indeed.

For the preparation of the CaFe-LDH, only the two-step milling procedure was used. The precursors were placed in the grinding jars and milled for 1 hour (dry milling), after which a certain amount of water was added to the system, then a 2 hour grinding (wet milling) was applied. In all the synthesis, the ball/sample weight ratio was kept at 100. This minimum value is necessary, as presented for CaAl-LDH. A set of parameters, the amount of added water, the grinding frequency, the Ca:Fe molar ratio, and the duration of dry milling were systematically varied in order to obtain a phasepure LDH as the product of the synthesis.

The first parameter to be optimized was the amount of added water $\left[n\left(\mathrm{H}_{2} \mathrm{O}\right): n(\mathrm{Fe})\right]$, which was varied in a wide range, from 25 to $900 \mu \mathrm{l}$ (Figure 27).

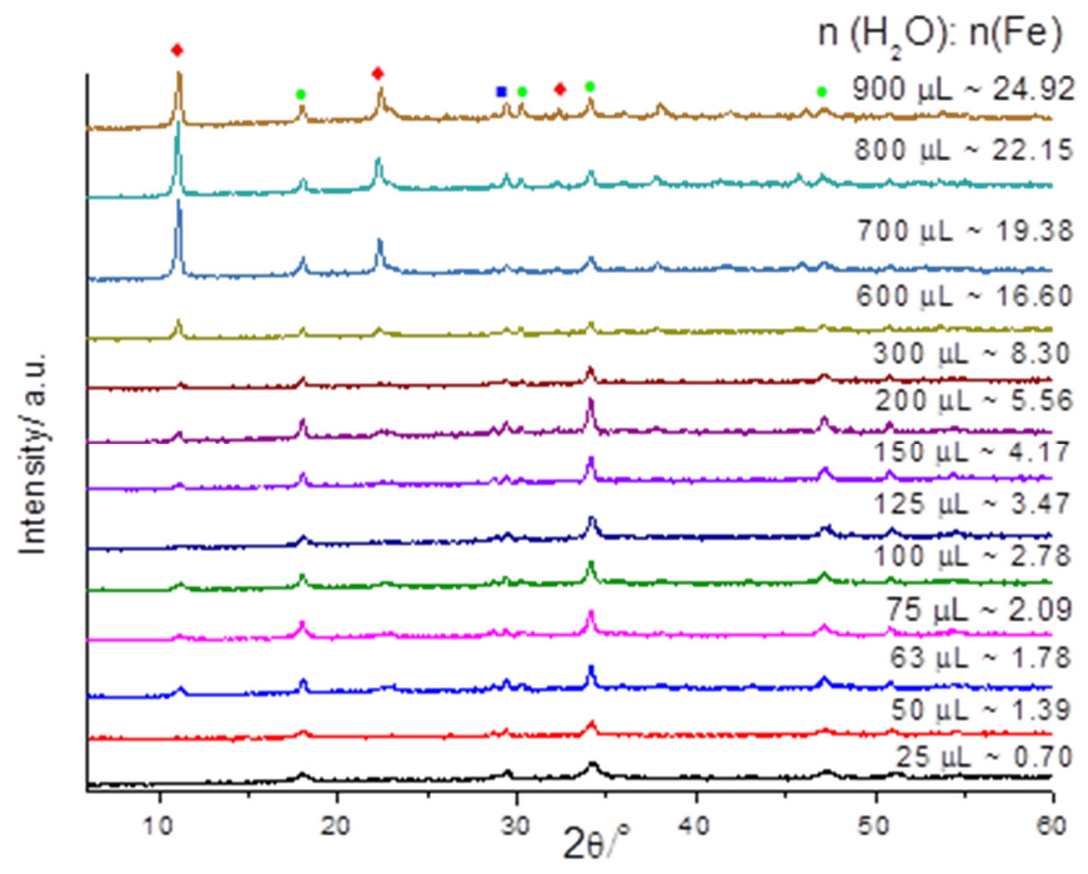

Figure 27. X-ray diffractograms of the milled Ca3Fe samples $(B / S=100, v=11.6 \mathrm{~Hz}$, dry milling $=1 \mathrm{~h}$, wet milling $=2 \mathrm{~h}$ ) after the systematic changes in the $\mathrm{H}_{2} \mathrm{O}: \mathrm{Fe}$ molar ratio, with the specific reflections of their components: red diamond - $\mathrm{LDH}$, green dot $-\mathrm{Ca}(\mathrm{OH})_{2}$, blue square $-\mathrm{CaCO}_{3}$

The diffractograms revealed that below $\mathrm{H}_{2} \mathrm{O}: \mathrm{Fe}$ molar ratio of 1.78 , no LDH formation took place. This means that the precursors did not provide sufficient amount of hydroxide groups for the LDHs to form. Increasing the amount of the added water until $\mathrm{H}_{2} \mathrm{O}: \mathrm{Fe}$ molar ratio of 16.6, no significant change could be observed in the intensities of the LDH reflections. However, at $\mathrm{H}_{2} \mathrm{O}$ :Fe molar ratio of 22.15 and above, 
the intensities of the (003) and (006) reflections increased significantly. For further experiments, the molar ratio value of 22.15 was selected.

The following parameter to be optimized was the duration of dry milling (Figure 28).

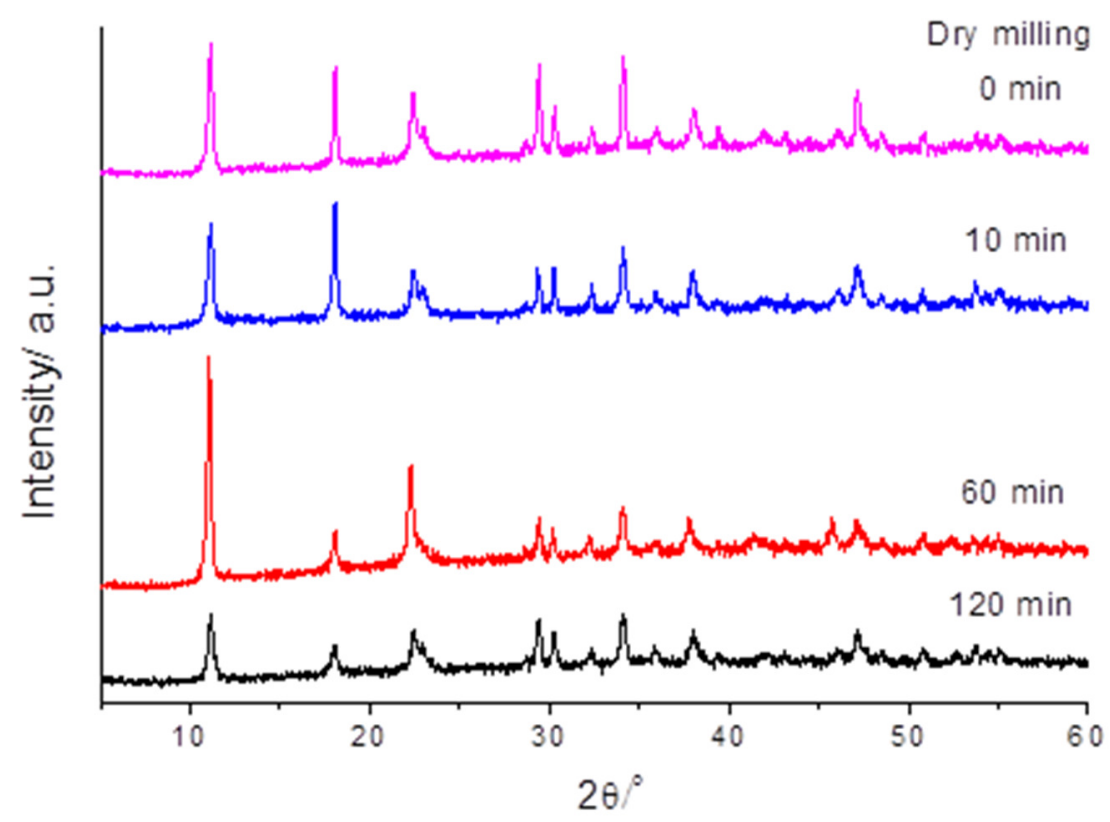

Figure 28. X-ray diffractograms of the milled Ca3 Fe samples $\left(\mathrm{B} / \mathrm{S}=100, v=11.6 \mathrm{~Hz}, n\left(\mathrm{H}_{2} \mathrm{O}\right): n(\mathrm{Fe})=22.15\right.$, wet milling $=2 \mathrm{~h}$ ) after systematic changes in the duration of dry milling

It was found that although LDH was formed without dry milling; the increase of the dry milling time increased the conversion of the reactants to LDH. It was expected, since the role of the dry milling is mechanically activating the surfaces. During mechanical activation several processes take place simultaneously, such as the increase in surface area, decrease in coherence energy of solids, increase in internal and surface energies, i.e., increase in reactivity in general [81]. The $1 \mathrm{~h}$ dry milling time seemed to be ideal for the LDH formation, thus, this value was used in further experiments.

The following parameter to vary was the grinding frequency. This was altered in a wide range, from $9.6 \mathrm{~Hz}$ to $13.6 \mathrm{~Hz}$ (Figure 29). The effect of the grinding frequency had similar effect on the LDHs, as for CaAl-LDHs. At lower grinding frequencies the intensities of the LDH reflections were smaller, reaching their maximum values at 11.6 Hz. At this frequency, the reflections were the sharpest as well; further increase in the grinding frequency resulted in the gradual loss of crystallinity. This effect is similar to the one observed for CaAl-LDHs, and has been described by Wang et al.[151], who studied the effect of the mechanochemical treatment on the already synthesized LDHs. They found that due to the mechanical treatment, the crystallinity of the samples decreased 
with the milling time until the total destruction of the solid crystal structure. Consequently, in further experiments the $11.6 \mathrm{~Hz}$ grinding frequency was used.

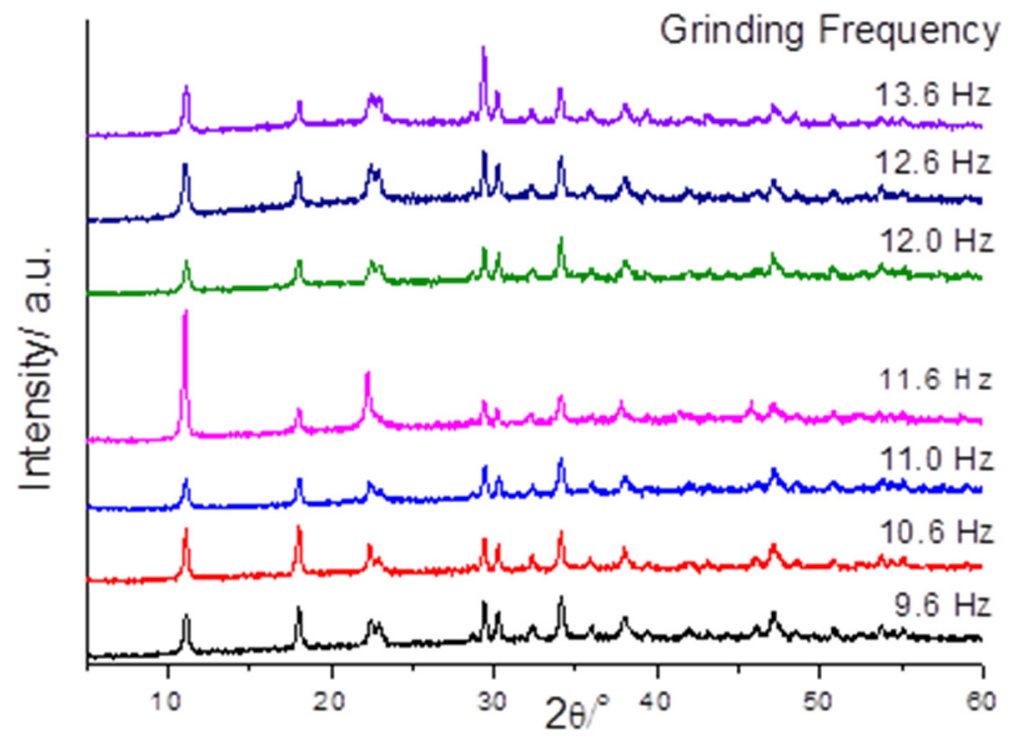

Figure 29. X-ray diffractograms of the milled Ca3Fe samples $(B / S=100$, dry milling $=1 \mathrm{~h}$, wet milling $=2 \mathrm{~h}$, $\left.n\left(\mathrm{H}_{2} \mathrm{O}\right): n(\mathrm{Fe})=22.15\right)$ after systematic changes of the grinding frequency

From the spectra even with the so far optimized parameters, it is clear that there are still unreacted precursors in the system - the reflections of the $\mathrm{Ca}(\mathrm{OH})_{2}$ are obvious -, while the increase in the baseline suggests the presence of $\mathrm{Fe}(\mathrm{OH})_{3}$. The presence of the $\mathrm{CaCO}_{3}$ is caused by the airborne $\mathrm{CO}_{2}$, which was not excluded during the preparation.

In order to minimize the excess $\mathrm{Ca}(\mathrm{OH})_{2}$ the $\mathrm{Ca}$ :Fe molar ratio was varied from $1: 1$ to 3:1 (Figure 30).

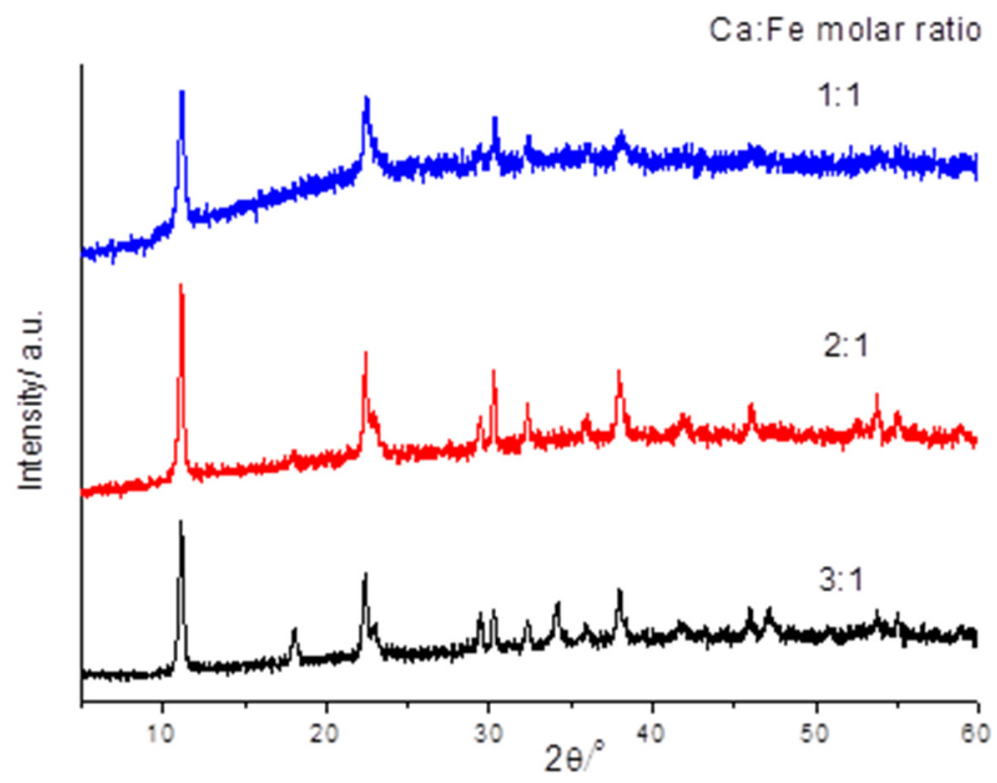

Figure 30. X-ray diffractograms of the milled CaFe-LDH samples with the systematic change in the Ca:Fe molar ratios $\left(\mathrm{B} / \mathrm{S}=100, v=11.6 \mathrm{~Hz}\right.$, dry milling $=1 \mathrm{~h}$, wet milling $\left.=2 \mathrm{~h}, n\left(\mathrm{H}_{2} \mathrm{O}\right): n(\mathrm{Fe})=22.15\right)$ 
When the Ca:Fe molar ratio was 2:1 the multiple reflections corresponding to the $\mathrm{Ca}(\mathrm{OH})_{2}$ phase disappeared, while using the $1: 1$ ratio, the substantial increase in the base line suggested that there was excess of $\mathrm{Fe}(\mathrm{OH})_{3}$ in the system. Therefore, the optimum conditions, under which phase-pure CaFe-LDH could be prepared (minor amount of $\mathrm{CaCO}_{3}$ was only formed) are $\mathrm{Ca}: \mathrm{Fe}$ and $\mathrm{B} / \mathrm{S}$ ratios of 2:1 and 100, respectively, $v=11.6 \mathrm{~Hz}$, dry milling = $1 \mathrm{~h}$, wet milling = $2 \mathrm{~h}, n\left(\mathrm{H}_{2} \mathrm{O}\right): n(\mathrm{Fe})=22.15$ (Figure 31).

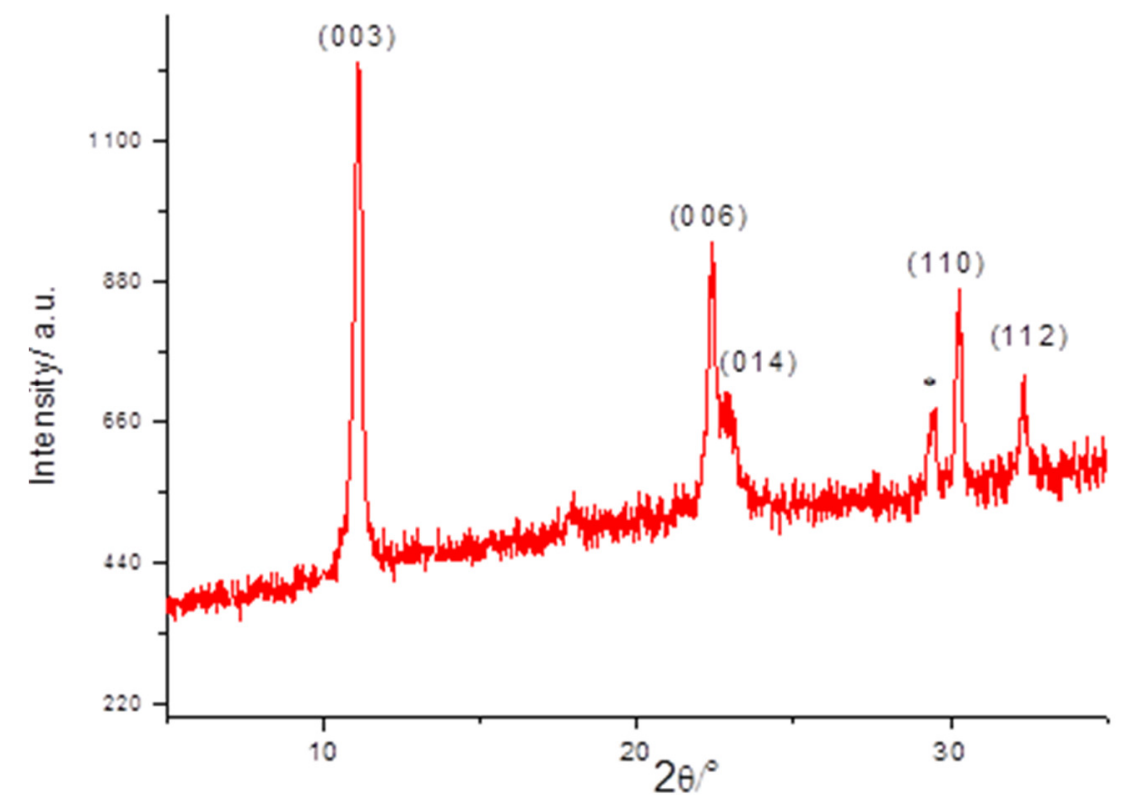

Figure 31. X-ray diffractogram of the milled CaFe-LDH sample under optimum conditions ( $\mathrm{Ca}: \mathrm{Fe}=2$, $n\left(\mathrm{H}_{2} \mathrm{O}\right): n(\mathrm{Fe})=22.15, \mathrm{~B} / \mathrm{S}=100, v=11.6 \mathrm{~Hz}$, dry milling $=1 \mathrm{~h}$, wet milling $=2 \mathrm{~h}$; $\left.{ }^{*} \mathrm{CaCO}_{3}\right)$

On the sample prepared with the optimized synthesis parameters, X-ray absorption, SEM, EDX and TG measurements were performed. The X-ray absorption spectrum of the sample, near the absorption edge, shows a very weak pre-edge peak at $7113 \mathrm{eV}$ (Figure 32), which corresponds to the $1 \mathrm{~s} \rightarrow 3 \mathrm{~d}$ transition in the $\mathrm{Fe}^{3+}$ ion; for a centrosymmetric octahedral site, the only mechanism available for the $1 \mathrm{~s} \rightarrow 3 \mathrm{~d}$ feature is the allowed electric quadrupole transition. An octahedral high-spin ferric complex should show two pre-edge features; however, it can be only detected with highresolution XAS[154]. 


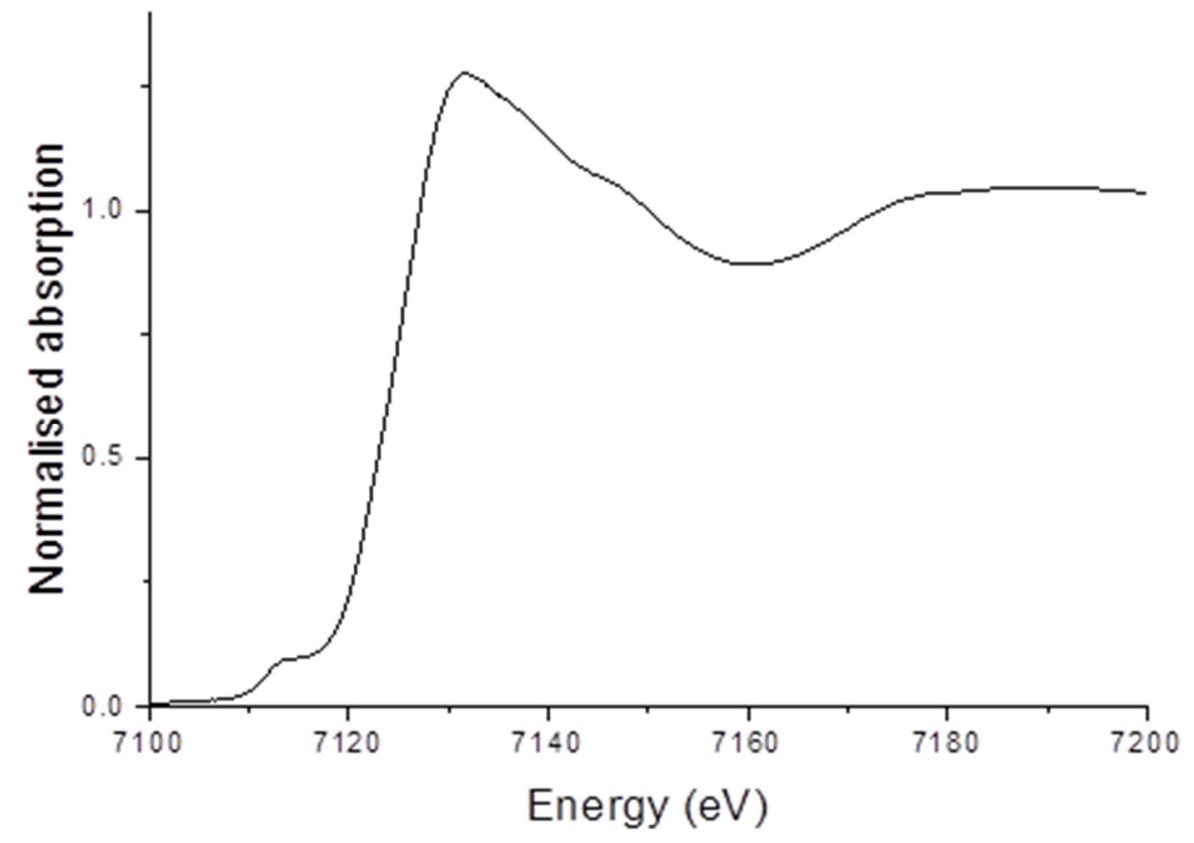

Figure 32. The Fe K-edge X-ray absorption spectrum of CaFe-LDH at the near-edge region

The Fourier-transformed EXAFS data (without phase correction) and the results of the fitting show the local chemical environment around the $\mathrm{Fe}^{3+}$ ions (Figure 33 and Table 8)

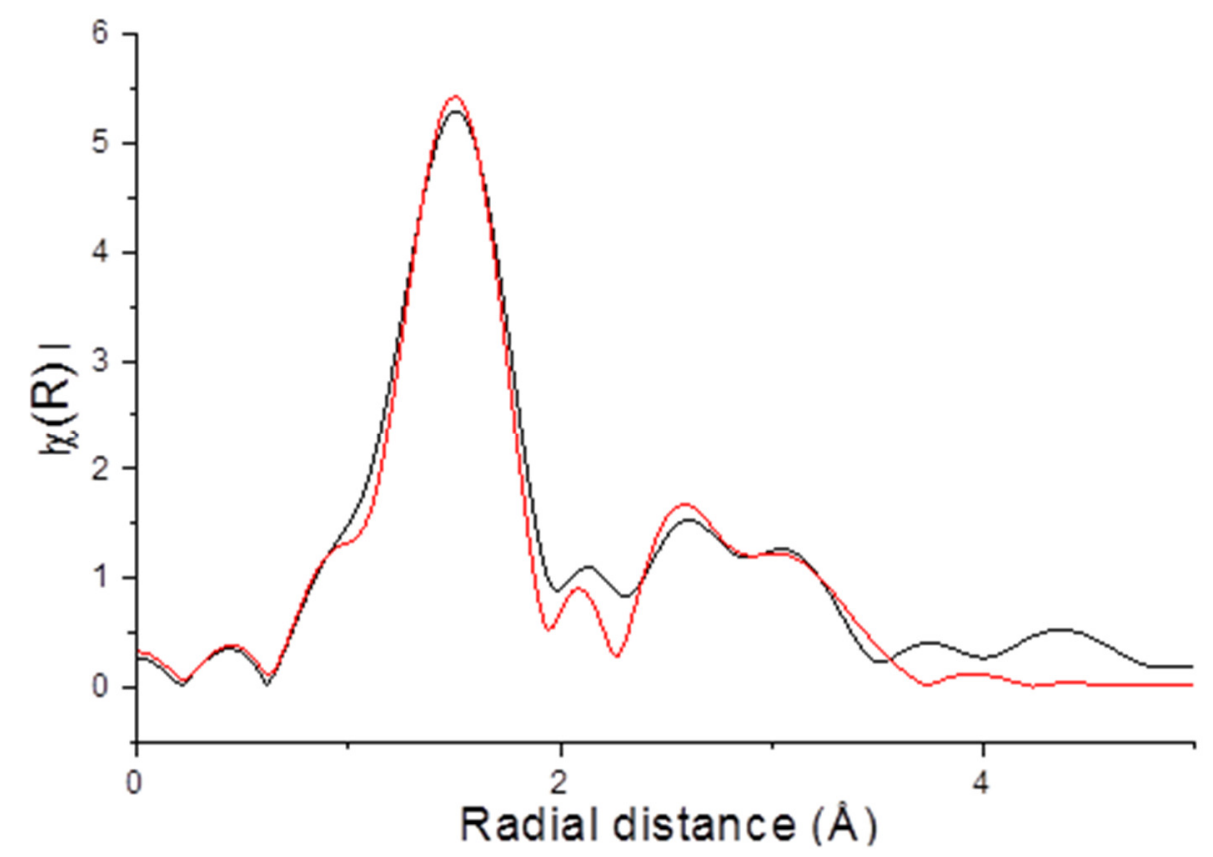

Figure 33. The Fourier-transformed EXAFS data (without phase correction) of CaFe-LDH, red line - fit, black line - experimental

In the first coordination shell, there are six oxygen atoms with a Fe-O interatomic distance of $1.99 \AA$. The second coordination sphere contains three $\mathrm{Ca}^{2+}$ ions, where the Fe-Ca interatomic distance was fitted to be $3.12 \AA$ and three other $\mathrm{Ca}^{2+}$ ions, where the Fe-Ca interatomic distance was determined to be $3.55 \AA$. 
Table 8. Parameters deduced from the fitted EXAFS spectrum ( $\mathrm{N}$ - coordination number, $\mathrm{R}$ - interatomic distance, $\sigma^{2}$ - Debye-Waller factor, $\Delta \mathrm{E}_{0}$ - energy shift, $\mathrm{R}$ factor - goodness of fit) for the pristine CaFe-LDH

\begin{tabular}{lllllll}
\hline Sample & $(\mathrm{Fe}-) \mathrm{X}$ & $\mathrm{N}$ & $\mathrm{R}(\AA)$ & $\sigma^{2}\left(\AA^{2}\right)$ & $\Delta \mathrm{E}_{0}(\mathrm{eV})$ & $\mathrm{R}$ factor \\
\hline CaFe-LDH & $\mathrm{O}$ & 6 & 1.99 & 0.0051 & -4.04 & 0.0120 \\
& $\mathrm{Ca}$ & 3 & 3.12 & 0.0104 & & \\
& $\mathrm{Ca}$ & 3 & 3.55 & 0.0083 & &
\end{tabular}

For easier visualization, a slab of a layer is depicted in Figure 34. The absence of $\mathrm{Fe}-\mathrm{O}-\mathrm{Fe}$ linkage confirms that the $\mathrm{Fe}^{3+}$ ions do not occupy neighboring sites, which would be unfavorable due to charge repulsion[11]. It is to be noted that EXAFS measurements performed for LDHs are not sensitive to the interlamellar species; the fitted data provide information on the local order around the cations in the layers only [155].

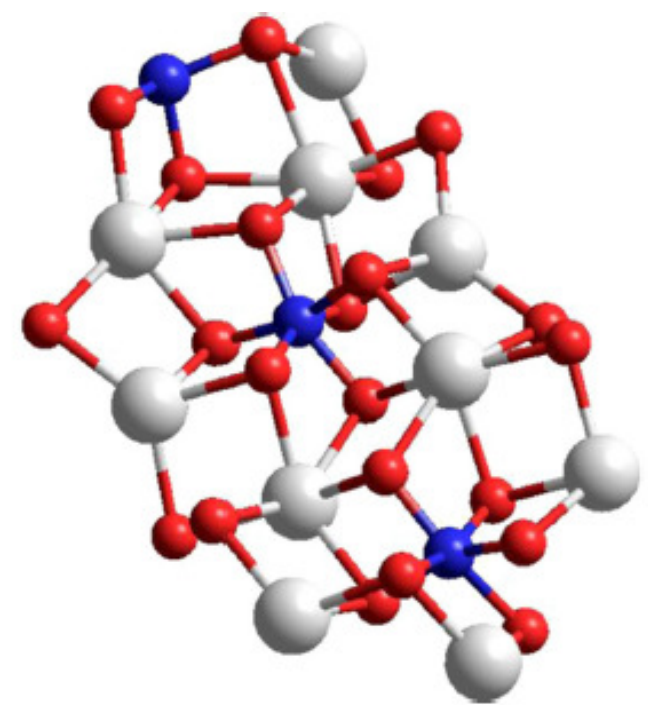

Figure 34.: A slab of a Ca(II)Fe(III)-LDH layer, to visualize the coordination environments deduced from the XAS measurement ( $\mathrm{Ca}$ - white, $\mathrm{Fe}$ - blue, $\mathrm{O}$ - red; hydrogens are omitted for increasing clarity)

The SEM images (Figure 35) display hexagonally-shaped particles, the typical morphology of LDHs. It is also clear that the morphologies of the precursors are significantly different from those of the samples.

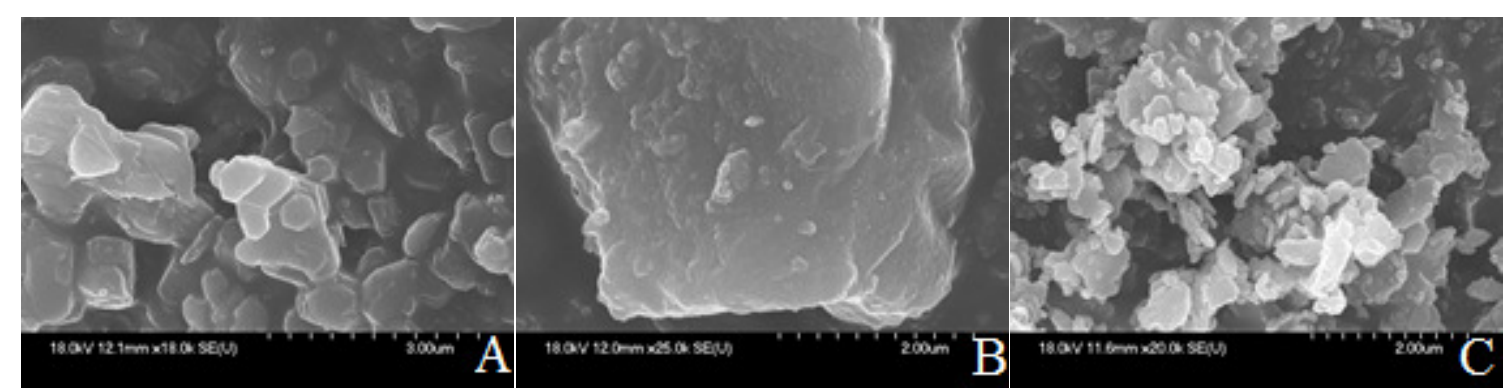

Figure 35. SEM images of $\mathrm{Ca}(\mathrm{OH})_{2}$ at a magnification of $18,000(\mathrm{~A}), \mathrm{Fe}(\mathrm{OH})_{3}$ at a magnification of 25,000 (B) and optimized $\mathrm{Ca} 2 \mathrm{Fe}-\mathrm{LDH}$ at a magnification of 20,000 (C) 
The elemental maps of the sample revealed that there was no aggregation or segregation of the elements within the particles (Figure 36), which is also a characteristic of the LDHs.

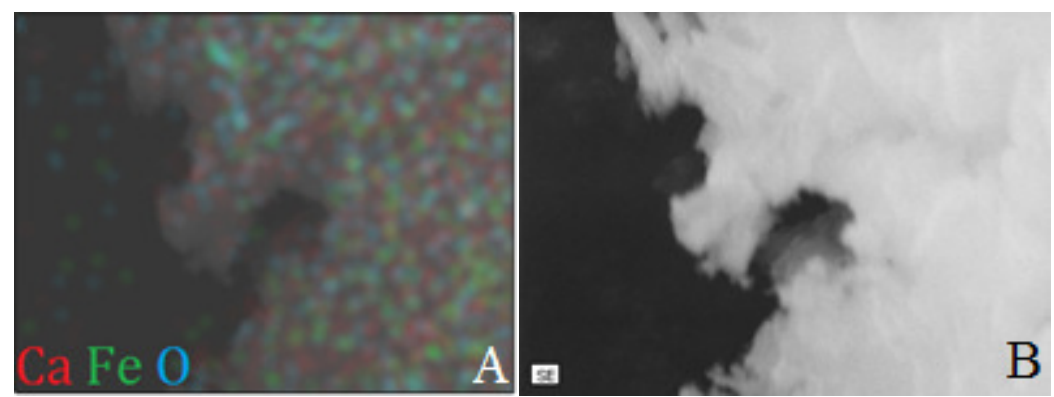

Figure 36. Elemental distribution map (A) on the $\mathrm{Ca} 2 \mathrm{Fe}-\mathrm{LDH}$ sample $(\mathrm{B})(\mathrm{B} / \mathrm{S}=100 ; \mathrm{v}=11.6 \mathrm{~Hz}$; $n\left(\mathrm{H}_{2} \mathrm{O}\right): n(\mathrm{Fe})=22.15$; dry milling $=1 \mathrm{~h}$; wet milling $=2 \mathrm{~h}$ )

LDHs have typical TG/dTG curves (Figure 37), having three major weight losses (around $100^{\circ} \mathrm{C}-$ physisorbed water, between $150^{\circ} \mathrm{C}$ and $250^{\circ} \mathrm{C}$ - interlayer water, between $425^{\circ} \mathrm{C}$ and $475^{\circ} \mathrm{C}$ dihydroxylation of the layers). All of these are clearly recognizable on the samples thermogravimetric curves.

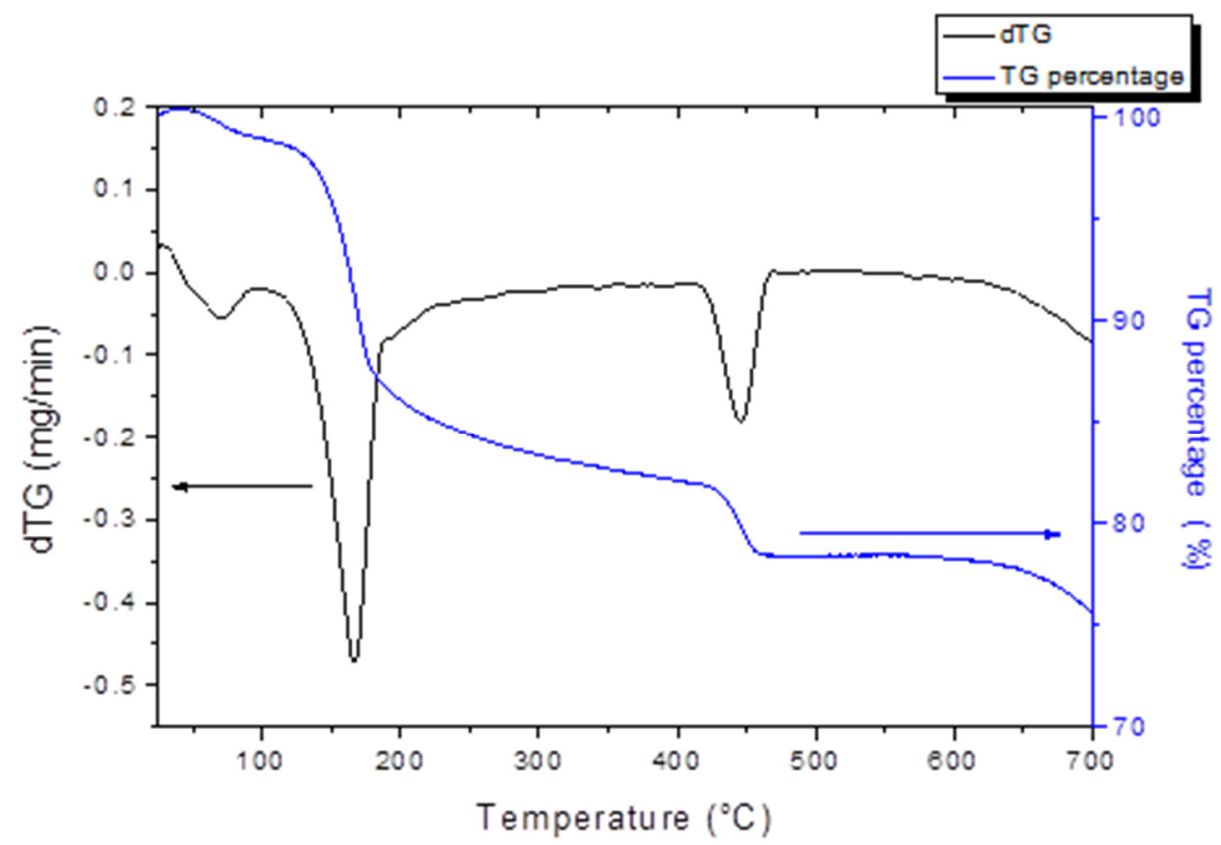

Figure 37. TG and dTG curves of the optimized Ca2 Fe-LDH

The combination of the methods described above, clearly indicate that using the two-step grinding procedure, phase-pure CaFe-LDH could be synthesized.

In both the synthesis of the CaAl- and CaFe-LDHs by using two-step milling operation in a mixer mill and systematically varying the experimental conditions, we could arrive at the nearly complete conversion of the precursors resulting in close-tophase-pure LDH. It has been revealed that although the addition of water (wet milling) is 
of utmost importance, the major parameter was the ball/sample ratio, i.e., the mechanochemical energy exerted.

\subsection{Intercalation of amino acid anions}

From the previous chapter, it can be seen that various pristine LDHs can be synthesized via using the mechanochemical method. Having these successful experimental protocols in hand, the intercalation of the anions of various amino acids (cystine, valine and tyrosine) was attempted.

\subsubsection{Intercalation of cystine and valine anions into Ca(II)Sn(IV)-LDHs}

The first attempt for the intercalation using mechanochemical methods was the intercalation of cystine (CysCys) and valine (Val) into $\mathrm{Ca}(\mathrm{II}) \mathrm{Sn}(\mathrm{IV})-\mathrm{LDH}$. For the preparation of these nanocomposites, a two-step milling method was used which was slightly modified relative to that leading to the pristine LDH. In this, after the dry milling of the precursors, the amino acids were added to the mixture under $\mathrm{N}_{2}$ atmosphere. In this step instead of distilled water (used in the preparation of the pristine LDH) $0.1 \mathrm{M}$ $\mathrm{NaOH}$ solution was used; then, wet milling took place. The samples prepared this way, with their designations, molar ratios and synthesis parameters are presented in Table 9.

Table 9. Samples prepared with the mechanochemically-assisted intercalation method: using mixer mill with two-step milling with the intercalated anion of cystine (_CysCys) or valine (_Val)

\begin{tabular}{|c|c|c|c|c|c|c|c|}
\hline Sample & $\begin{array}{l}\mathrm{Ca}(\mathrm{II}): \mathrm{Sn}(\mathrm{IV}) \\
\text { molar ratio }\end{array}$ & $\begin{array}{l}\mathrm{Sn}(\mathrm{IV}): \mathrm{A}^{-\mathrm{a})} \\
\text { molar ratio }\end{array}$ & $\begin{array}{l}\text { Frequency } \\
\qquad(\mathrm{Hz})\end{array}$ & $\mathrm{B} / \mathrm{S}$ & $\begin{array}{c}\text { Added } \\
0.1 \mathrm{M} \\
\mathrm{NaOH} \\
(\mu \mathrm{L})\end{array}$ & $\begin{array}{c}\text { Dry } \\
\text { milling } \\
\text { (h) }\end{array}$ & $\begin{array}{c}\text { Wet } \\
\text { milling } \\
\text { (h) }\end{array}$ \\
\hline Ca3Sn_CysCys & $3: 1$ & $1: 1$ & 11.6 & 100 & 200 & 1 & 2 \\
\hline Ca3Sn_Val & $3: 1$ & $1: 1$ & 11.6 & 100 & 200 & 1 & 2 \\
\hline
\end{tabular}

a) $\mathrm{A}^{-}$represents the intercalated anion

The diffractograms of the intercalated samples and that of the pristine LDH are displayed in Figure 38. One of the most important proofs that the intercalation of the anions between the layers of the LDH succeeded is the change in the interlayer spacing. This change can be calculated from the position of the (003) reflection, using the Bragg equation. The lower the position of the (003) reflection in terms of $2 \theta$ angle, the larger the interlayer distance is. Thus, in the samples prepared, one is looking for the increased interlayer spacing, i.e., the presence of the (003) reflection at lower $2 \theta$ values relative to the pristine $\mathrm{Ca}(\mathrm{II}) \mathrm{Sn}(\mathrm{IV})-\mathrm{LDH}$ sample. 


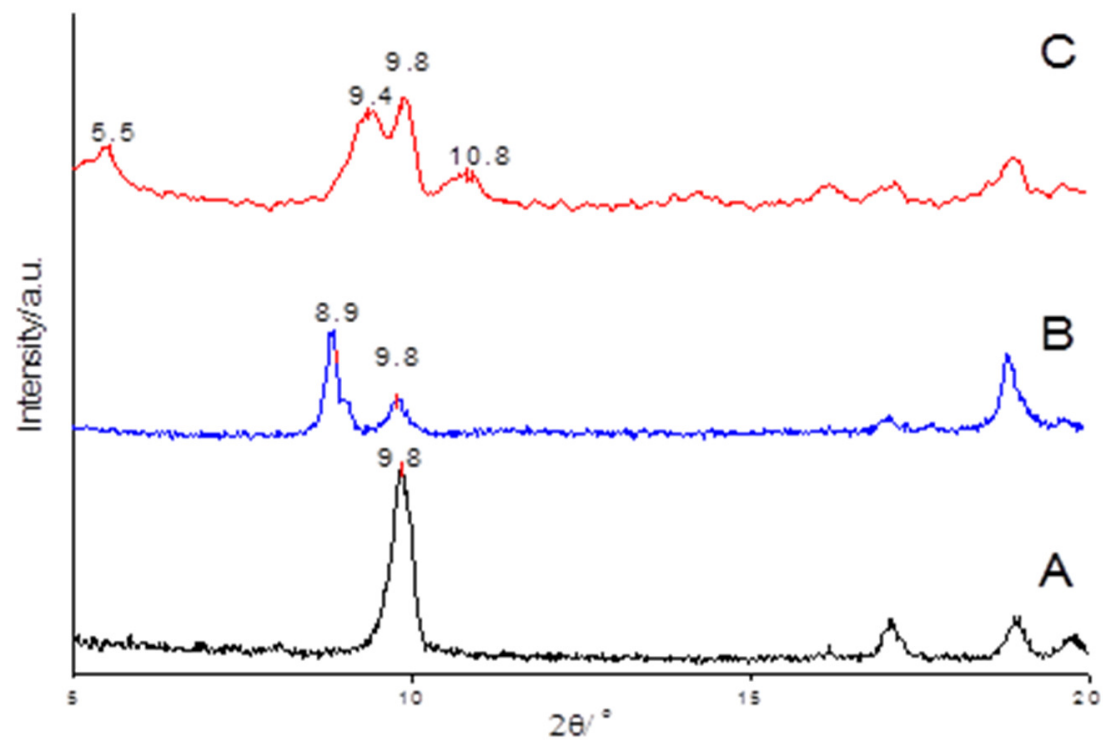

Figure 38. Powder X-ray diffractograms of the amino acid anion-Ca(II)Sn(IV)-LDH samples intercalated by the mechanochemically-assisted pathway: (A) Ca3sn_mm_w. (B) Cas3Sn_Val, (C) Ca3sn_CysCys

In both cases (using the anions of cystine or valine), this phenomenon could be observed. For the samples containing the anions of valine and cystine, the (003) reflection shifted to $8.8^{\circ}$ and $5.6^{\circ}$ from $9.8^{\circ}$ in the pristine LDH. The calculated interlayer spacings are summarized in Table 10.

Table 10. The interlayer distances of the pristine and intercalated Ca(II)Sn(IV)-LDHs

\begin{tabular}{lc}
\hline Sample & Interlayer spacing $(\AA)$ \\
\hline $\mathrm{Ca} 3 \mathrm{Sn} \_m n_{-}$w & 9.01 \\
$\mathrm{Ca} 3 \mathrm{Sn}$ VVal & 9.99 \\
$\mathrm{Ca} 3 \mathrm{Sn}$ _CysCys & 15.65 \\
\hline
\end{tabular}

Additional support for the success of intercalation is provided by SEM-EDX measurements. Using this method, the elemental distribution maps were taken, shown in Figure 39 and Figure 40.

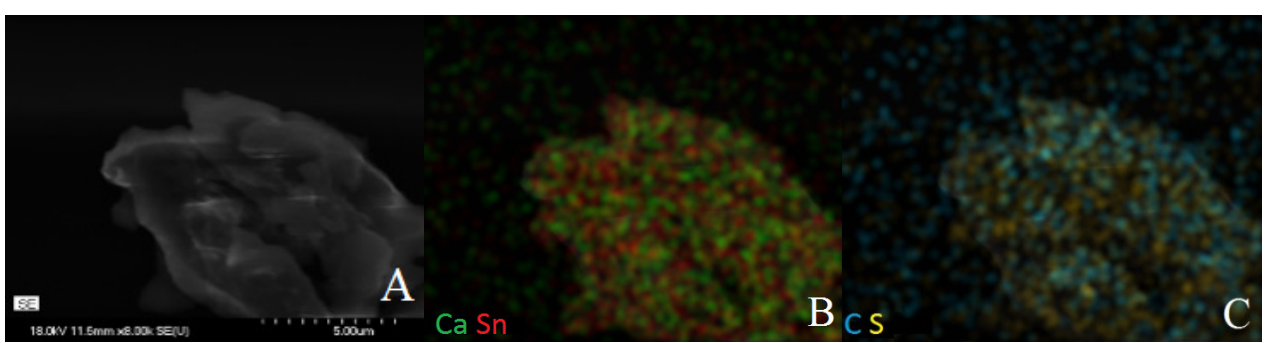

Figure 39. Ca-Sn (B) and C-S (C) elemental distribution maps on the $\mathrm{Ca}_{3} \mathrm{Sn}_{-} \mathrm{CysCys}$ sample (A) 


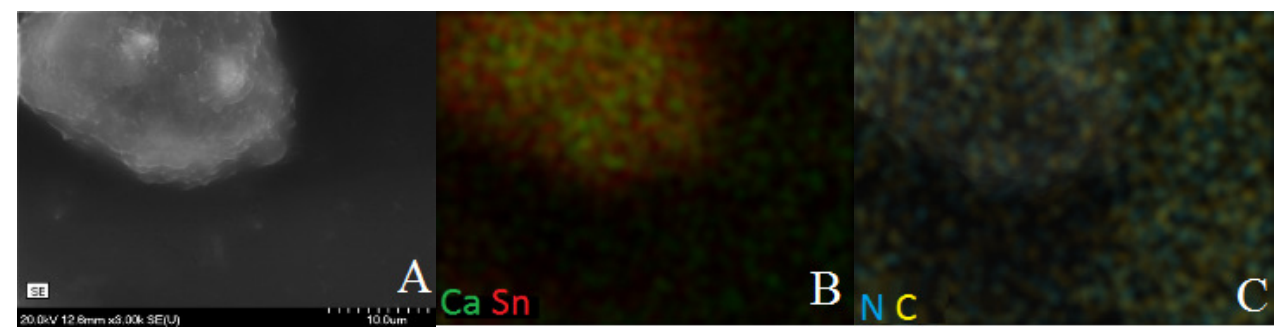

Figure 40. Ca-Sn (B) and N-C (C) elemental distribution maps on the $\mathrm{Ca}_{3} \mathrm{Sn}_{-}$Val sample (A)

The $\mathrm{C}-\mathrm{S}$ and $\mathrm{N}-\mathrm{C}$ elemental maps revealed that the distributions of the amino acid anions were uniform in both cases. The $\mathrm{Ca}-\mathrm{Sn}$ elemental maps show that these two elements are also evenly distributed within the particle (which is one of the characteristics of the LDHs).

Other conclusive information could be gained regarding the success of the intercalation by IR spectroscopy. The IR spectra of the intercalated samples were taken and compared to those of the pristine LDH and the amino acids in zwitter ionic forms (Figure 41 and Figure 42).

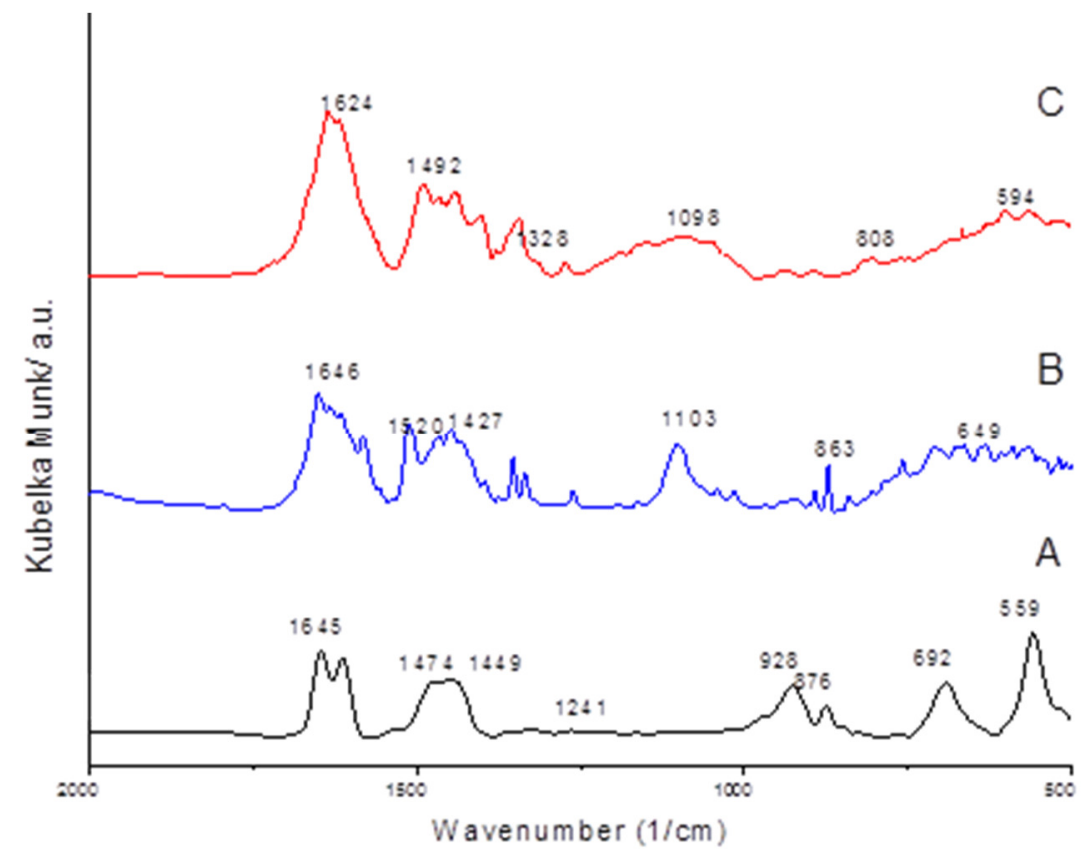

Figure 41. FT-IR spectra of $\mathrm{Ca}_{3} \mathrm{Sn} \_\mathrm{mm} \_w(\mathrm{~A}), \mathrm{Ca}_{3} \mathrm{Sn}_{-}$Val (B), and the zwitter ionic DL-valine (C) 


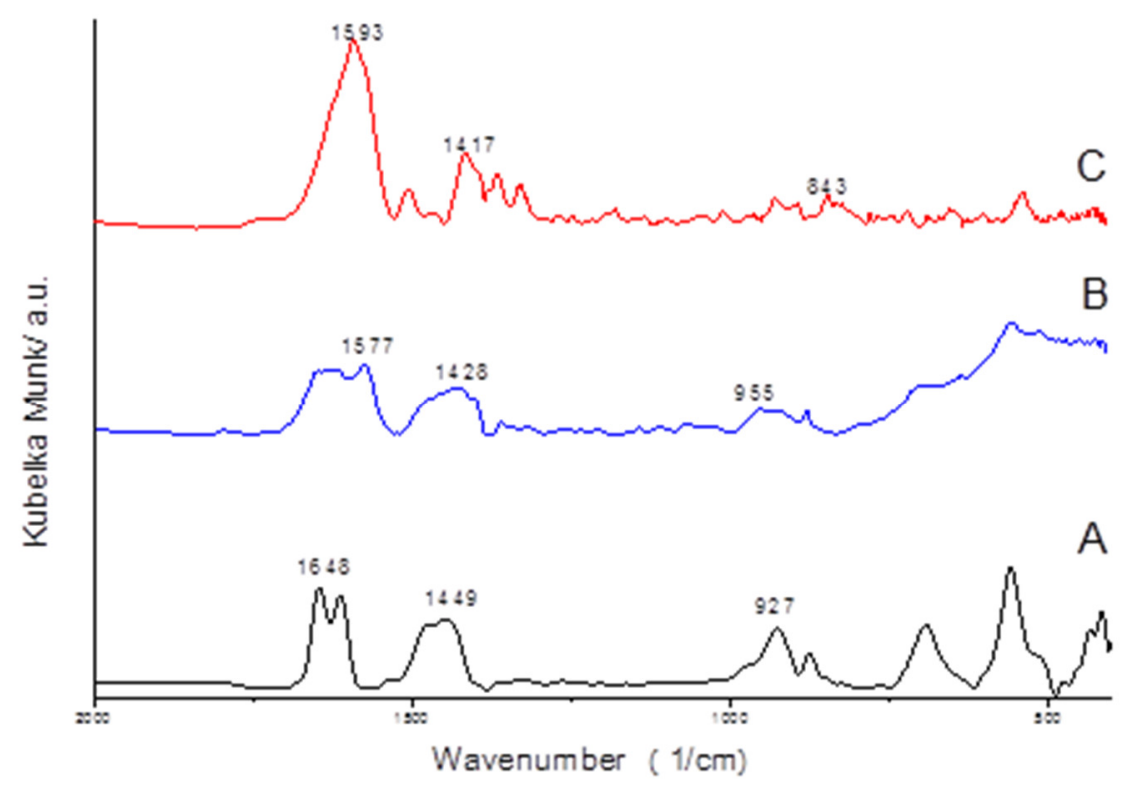

Figure 42. FT-IR spectra of $\mathrm{Ca}_{3} \mathrm{Sn}_{-} \mathrm{mm}_{-} w(\mathrm{~A}), \mathrm{Ca}_{3} \mathrm{Sn}_{-} \mathrm{CysCys}(\mathrm{B})$, and the zwitter ionic L-cystine (C)

At around $1100 \mathrm{~cm}^{-1}$, the symmetric stretching vibration of the $\mathrm{C}-\mathrm{N}$ bond is present in the spectra of both the intercalated sample and the zwitter ionic valine, and is not seen in the pristine LDH. This finding verifies that an organic-inorganic composite is in our hands. The presence of the carboxylate ion vibrations is an additional evidence. Actually, the band corresponding to the asymmetric vibration can only be identified in the composite, since the symmetric vibration coincides with a band of the pristine LDH at $1645 \mathrm{~cm}^{-1}$. Nevertheless, this peak shifted from $1492 \mathrm{~cm}^{-1}$ to $1520 \mathrm{~cm}^{-1}$ indicating interaction with the layer of the $\mathrm{LDH}$, i.e., the carboxylate ion is situated among the layers.

A similar reasoning may be given for the interaction of the LDH and the anion of cystine, since here, the symmetric carboxylate band can be identified too, and it also shifts in the composite compared to the zwitter ionic form (the shift is smaller though than in the previous case, it is from $1417 \mathrm{~cm}^{-1}$ to $1428 \mathrm{~cm}^{-1}$ ). In order to support the conclusion that the anion of cystine was also intercalated, measurements with Raman spectroscopy were also performed (Figure 43).

The C-S bond stretching vibration at $499 \mathrm{~cm}^{-1}$ appeared in the Raman spectrum of the zwitter ionic L-cystine, and it is seen and shifted to $472 \mathrm{~cm}^{-1}$ in that of the composite sample as well. This confirms that the intercalation of the anion of cystine into Ca3SnLDH. 


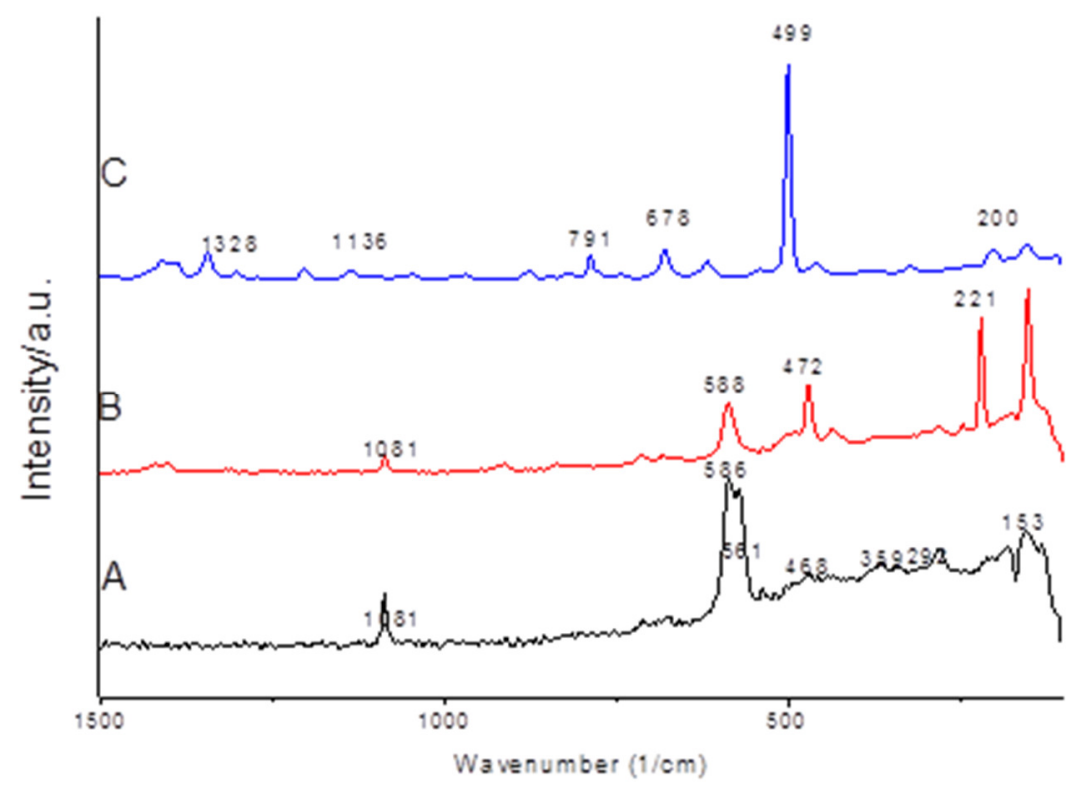

Figure 43. Raman spectra of $\mathrm{Ca}_{3} \mathrm{Sn}_{-} \mathrm{mm}_{-} \mathrm{w}(\mathrm{A}), \mathrm{Ca}_{3} \mathrm{Sn}_{-} \mathrm{CysCys}(\mathrm{B})$, and L-cystine (C)

It can be stated that intercalation of organic anions is possible with mechanochemistry, but the intercalation should still be optimized, given that in both cases, there was still pristine LDH in the system.

\subsubsection{Intercalation of cystine and tyrosine into Ca(II)Fe(III)-LDHs}

For the optimization of the intercalation, the $\mathrm{Ca}(\mathrm{II}) \mathrm{Fe}(\mathrm{III})$ system was used. After the successful synthesis of the pristine LDH, the intercalation of the anions of various amino acids (tyrosine, cystine) was attempted. Three variations of intercalation were applied.

Intercalation with amino acid and $\mathrm{NaOH}$ (Method 1): In this method, the first step of the intercalation method was the dry milling of the $\mathrm{Ca}(\mathrm{OH})_{2}$ and the $\mathrm{FeCl}_{3} \cdot 6 \mathrm{H}_{2} \mathrm{O}$. After the 1-h dry milling, in a glovebox under $\mathrm{N}_{2}$ atmosphere, amino acid (used as received), in powder form was added to the milled precursors. Then, $3 \mathrm{M} \mathrm{NaOH}$ solution was added to this mixture. The grinding jars were sealed under $\mathrm{N}_{2}$ atmosphere, and the wet milling was started. After the wet milling, the product was washed with distilled water several times, then dried and kept in a desiccator.

Intercalation using an alkaline solution of the amino acid (Method 2): In this method, previous to the grinding of the $\mathrm{Ca}(\mathrm{OH})_{2}$ and $\mathrm{FeCl}_{3} \cdot 6 \mathrm{H}_{2} \mathrm{O}$, concentrated alkaline solution of the amino acid was prepared using the amino acid powders as received and 3 $\mathrm{M} \mathrm{NaOH}$ solution. The concentration of this solution for the amino acid was $1.4 \mathrm{M}$. The 
first step of this method, was also the dry milling of the $\mathrm{Ca}(\mathrm{OH})_{2}$ and $\mathrm{FeCl}_{3} \cdot 6 \mathrm{H}_{2} \mathrm{O}$. After that, the previously prepared concentrated solution (containing the amino acid anions) was added to the milled precursors under $\mathrm{N}_{2}$ atmosphere; then, the wet milling started. After the wet milling step, the product was washed with distilled water several times, then dried and kept in a desiccator.

Intercalation using the Na salts of the amino acid and water (Method 3): In this method before grinding the precursors, the Na salt of the amino acid was prepared. To do this, from some of the previously prepared amino acid alkaline solution the Na salts of the amino acids were precipitated. The precipitated Na salt was added to the mixture in the grinding jars, after the dry milling step. After this, minute amounts of water were also added, and the wet milling step was started. Then, the product was washed with distilled water several times, then dried and kept in a desiccator.

\subsubsection{L-Cystine}

First, the experiments were performed with cystine (CysCys). While keeping to optimized conditions identified for the synthesis of the pristine LDH, parameters of the intercalation process, such as the $\mathrm{NaOH}: \mathrm{Fe}$ molar ratio, the CysCys:Fe molar ratio, and different forms of the amino acid (L-cystine, an alkaline solution of cystine, and the $\mathrm{Na}$ salt of cystine) were studied.

Upon changing the NaOH:Fe molar ratio (Figure 44) and keeping the CysCys:Fe molar ratio at 1:1, the cystine molecule as purchased and $3 \mathrm{M} \mathrm{NaOH}$ solution were added to the precursors between the dry and wet milling steps (Method 1). This way, competition was induced between the formation of the LDH and that of the cystinate anion. It is obvious that with small amount of added base, neither the LDH formation nor the intercalation took place. At $\mathrm{NaOH}$ :Fe ratio of above 1.6, both the pristine and the cystinate-intercalated LDH could be seen, while at $\mathrm{NaOH}: \mathrm{Fe}=3$, only the pristine LDH's reflections were present. These observations mean that at low base quantities, there is not enough hydroxide groups in the system for the LDH to form, and neither could the intercalation take place. Raising the amount of the $\mathrm{NaOH}$, i.e., the $\mathrm{pH}$, there were enough hydroxide groups for the $\mathrm{LDH}$ to form, the cystine can partially transform to its anionic form, and the intercalation process could occur to some extent. The intercalation possibly took place as a direct anion change, first the $\mathrm{LDH}$ was formed with $\mathrm{Cl}^{-}$as charge compensating ion; then chloride was replaced by the cystinate anion. On the basis of 
these experimental observations, it is suggested that the chloride and cystinate ions could bind to the layers with similar strengths, and their competition resulted in the appearance of the two sets of LDH.

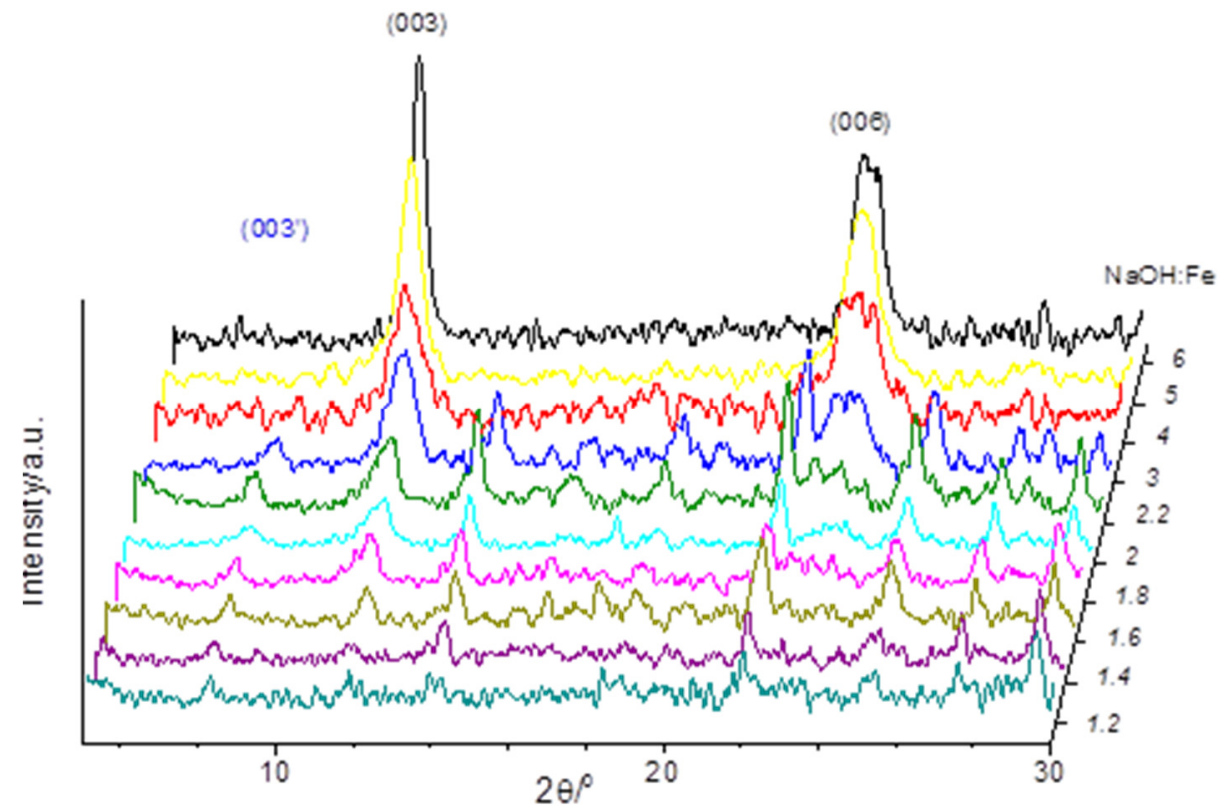

Figure 44. X-ray diffractograms of the cystinate-intercalated $\mathrm{Ca}_{2} \mathrm{Fe}$ samples, with the systematic change of the $\mathrm{NaOH}: \mathrm{Fe}$ molar ratio (CysCys:Fe $=1: 1$ )

On further increasing the amount of base, the pristine LDH was the only product. At high $\mathrm{pH}$, the $\mathrm{LDH}$ was formed with $\mathrm{Cl}^{-}$as counter ion first; then the $\mathrm{Cl}^{-}$was substituted for the $\mathrm{OH}^{-}$, since the $\mathrm{OH}^{-}$can bond more strongly to the layers. This intercalated $\mathrm{OH}^{-}$, having one of the strongest interaction with the layers, forbids the cystine in anionic form to intercalate, thus, the cystine can only bound to the outer surface of the LDH.

The following parameter to be systematically changed was the CysCys:Fe molar ratio. It was varied from 0.5 to 5 (Figure 45). Similar trends can be noticed to the case, when the NaOH:Fe molar ratio was altered. At low CysCys:Fe values, mainly the pristine LDH was formed and the cystinate-intercalated LDH was also present, albeit in very small quantities. Here, the amount of cystine was significantly smaller than that of the base; therefore, the intercalation of the $\mathrm{OH}^{-}$group was more favorable. Increasing the amount of the cystine (CysCys:Fe $=1.5$ seems to be the optimum value), the 003 reflection of the intercalated $\mathrm{LDH}$ became more intense, but the pristine LDHs reflections were still there. This is due, as was mentioned before, to the competition between the cystinate and the chloride ions. Further increase in the amount of the cystine, the intensities of the LDHs decrease to a point (CysCys:Fe $=5$ ), where all of the 
reflections assigned to the LDHs disappear. In this case, the total weight of the sample was so big that the $B / S$ ratio decreased to the point where the necessary amount of mechanical energy could not be transmitted for the LDH to form.

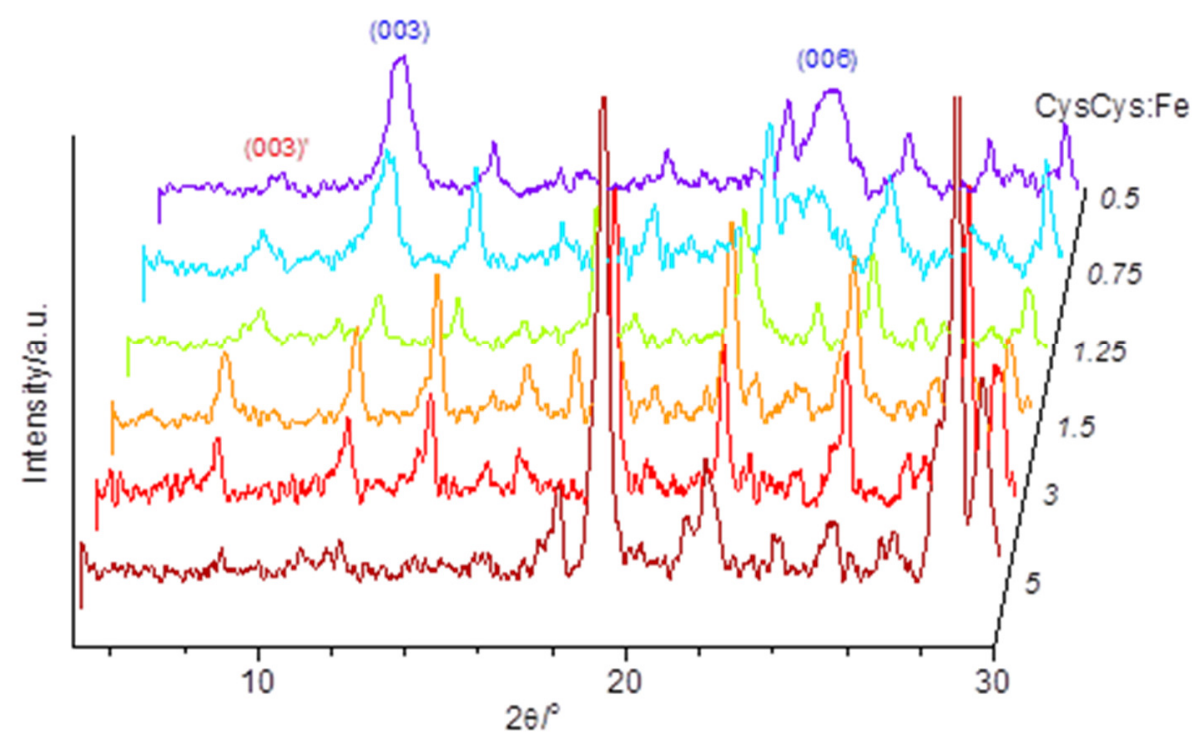

Figure 45. $7 \mathrm{X}$-ray diffractograms of the cystinate-intercalated $\mathrm{Ca}_{2} \mathrm{Fe}$ samples with the systematic change of the CysCys:Fe molar ratio ( $\mathrm{NaOH}: \mathrm{Fe}=2.2)$

The sample with the 1.5 CysCys:Fe molar ratio (designated as CysCys(1.5)-CaFeLDH) was selected, and further studied with SEM and SEM-EDX measurements. The SEM images (Figure 46) reveal the typical morphology of the LDHs: well-developed and very regular, lamellar-shaped hexagonal particles are seen.

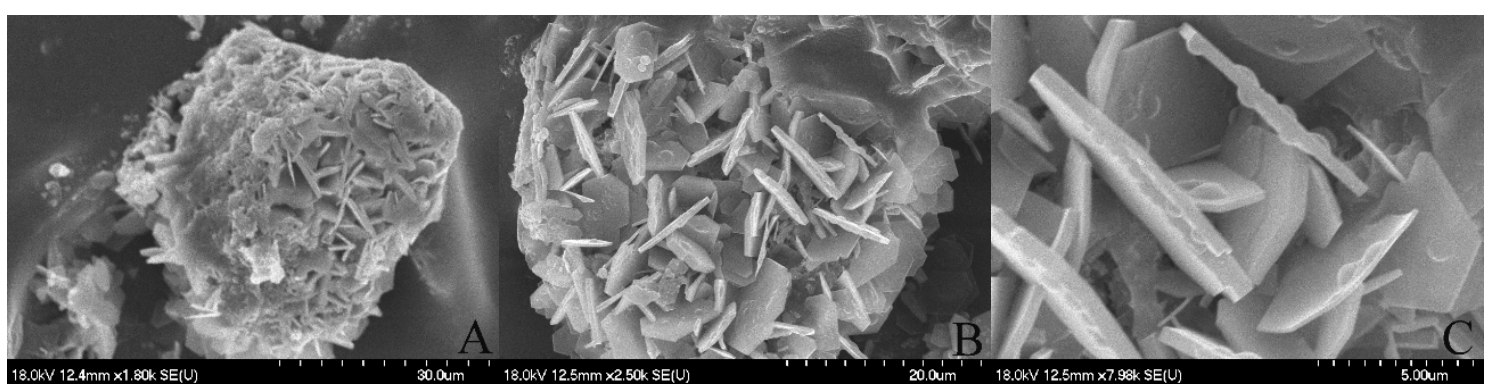

Figure 46. SEM images of the CysCys(1.5)-Ca2Fe-LDH sample ( $\mathrm{NaOH}: \mathrm{Fe}=2.2$, CysCys:Fe = 1.5); magnifications: $1,800(\mathrm{~A}), 2,500(\mathrm{~B})$ and $7,980(\mathrm{C})$

The elemental maps (SEM-EDX measurements, Figure 47) attest the presence of iron and calcium as well as carbon and sulfur. They are uniformly dispersed within the particles, no segregation or aggregation of the elements could be noticed. The cystinate ions were mainly among the layers of the LDH, since substantial decrease in the position of the first reflection relative to that of the pristine LDH was observed on one hand, and 
the morphology of Na-cystinate (Figure 48) differed significantly from that of the CysCys(1.5)-CaFe-LDH sample on the other.

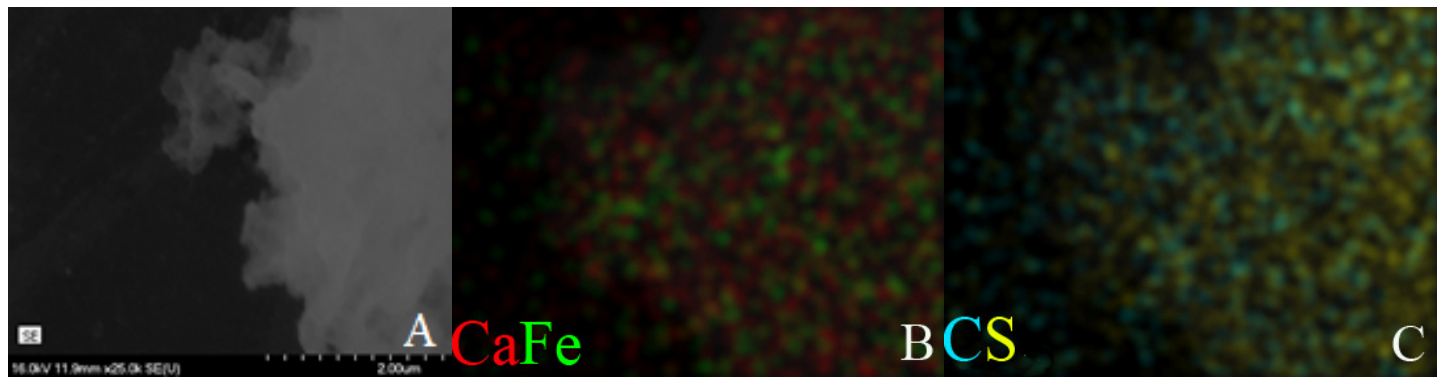

Figure $47 \mathrm{Ca}-\mathrm{Fe}(\mathrm{B})$ and C-S (C) elemental distribution maps on the CysCys(1.5)-Ca2Fe-LDH sample (A) at a magnification of 25,000

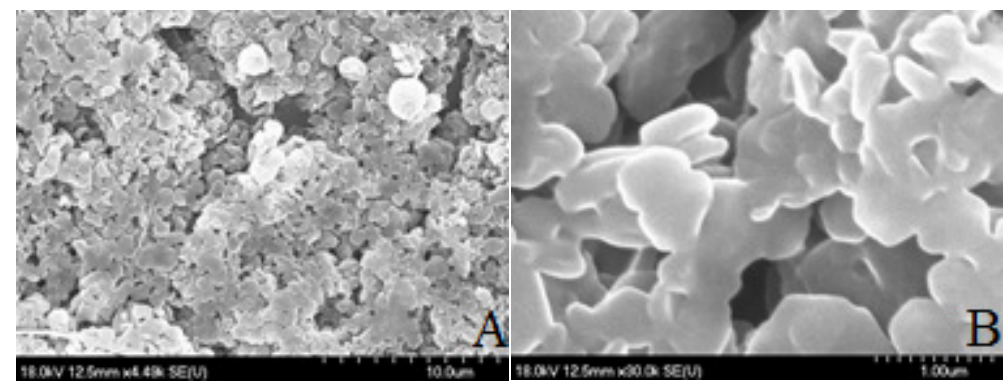

Figure 48. SEM images of Na-cystinate; magnifications: 4,500 (A) and 30,000(B)

In another set of experiments, saturated solution of L-cystine was reacted with $\mathrm{NaOH}$ (the concentration for cystine was $1.4 \mathrm{M}$ ), and this solution was added in the wet milling process (Method 2). Now, it was certain that cystine was in anionic form from the beginning, and the excess base could fully be used in the formation of the LDH. The diffractograms of the samples prepared this way are presented in Figure 49.

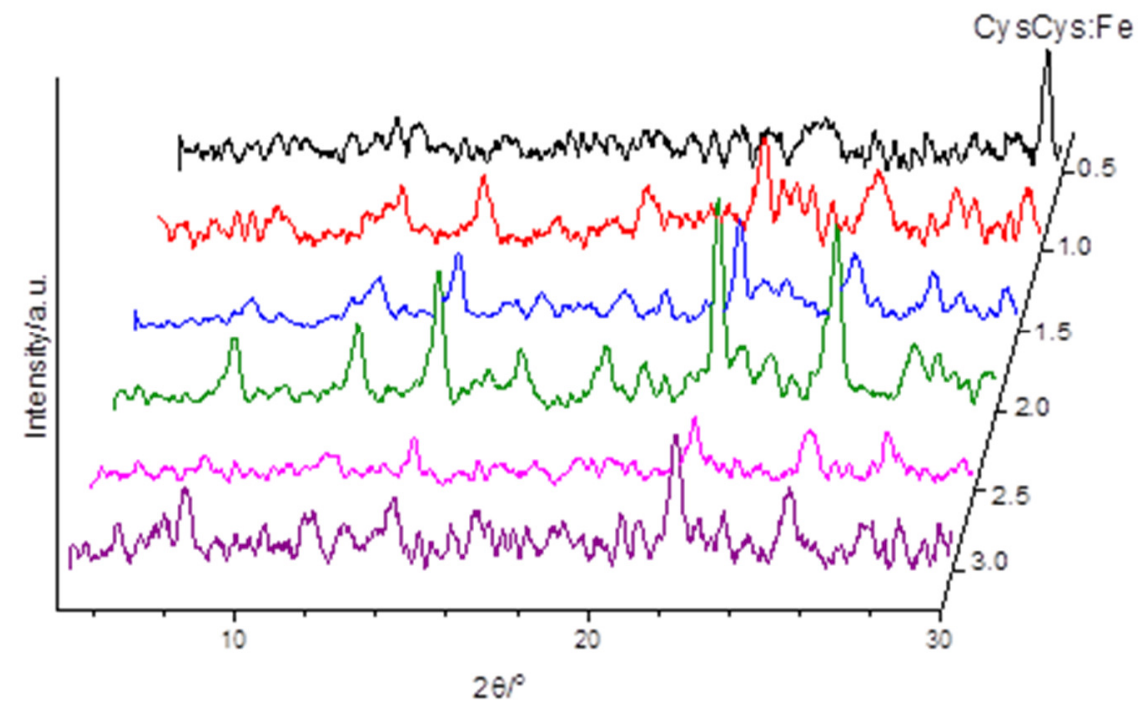

Figure 49. X-ray diffractograms of the cystinate-intercalated $\mathrm{Ca}_{2} \mathrm{Fe}$ samples, with the systematic change of the CysCys:Fe molar ratio using saturated cystine solution (concentration: $1.4 \mathrm{M}$ ) and excess $3 \mathrm{M} \mathrm{NaOH}$ 
At low quantities of cystine, there was no LDH formation, since the amount of the base was also low, clearly, it was not sufficient for the LDH to form. Increasing the amount of added cystinate solution, the intensities of the reflections typical of the LDH increased up to CysCys:Fe = 2. Just like before, reflections of the intercalated LDH as well as the pristine LDHs indicated that both substances were present. Above this ratio, the reflections of the LDHs disappeared. This may be due to the increased amount of cystinate solution consuming the mechanical energy; thus, there is not enough left for the LDH to form. The sharpest and most intense reflections were produced by the sample having the CysCys:Fe ratio of 2. This sample was further investigated using SEM (Figure 51), SEM-EDX (Figure 52), IR (Figure 53), and X-ray absortion (Figure 50).

The X-ray absorption spectrum and EXAFS data show (Figure 50 and Table 11) the characteristics of the LDH described above, i.e., during intercalation the layers of the host material was not harmed.
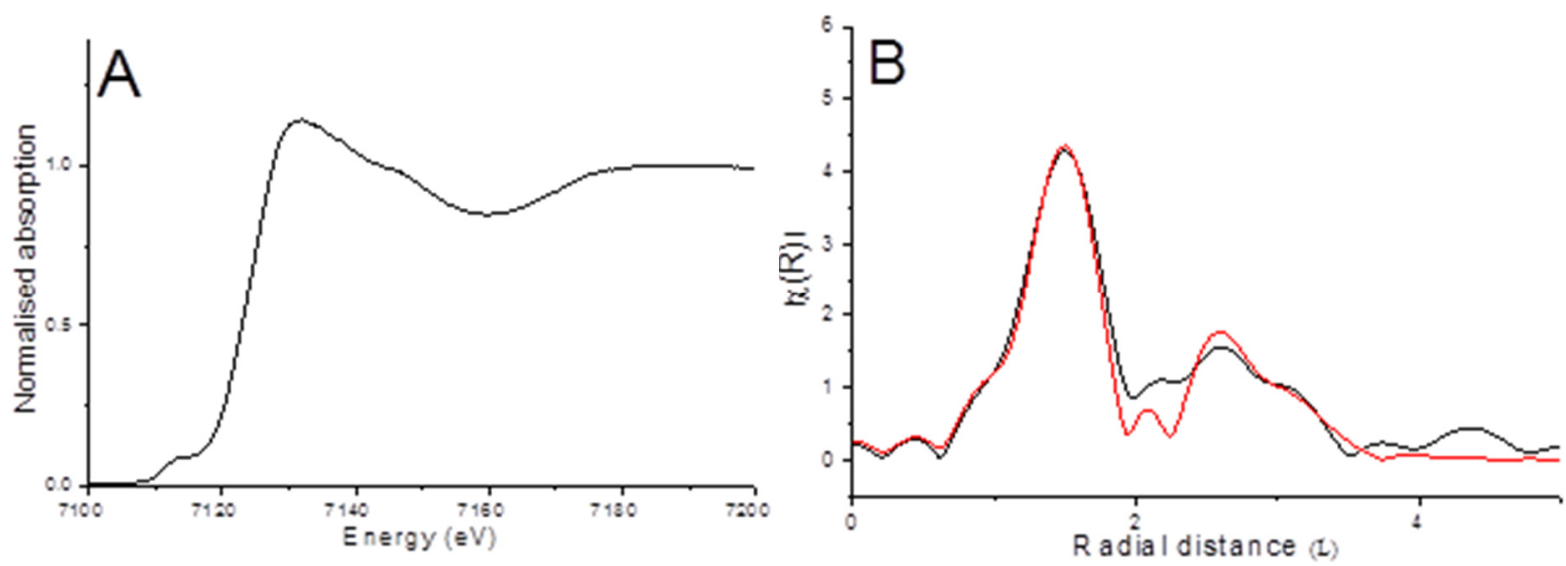

Figure 50. X-ray absorption spectrum at the near-edge region (A) and the Fourier-transformed EXAFS data (B) (without phase correction; red line - fit, black line - experimental) of the CysCys(2)-Ca2 $\mathrm{Fe}-\mathrm{LDH}$ sample

Table 11. Parameters deduced from the fitted EXAFS spectrum ( $\mathrm{N}$ - coordination number, $\mathrm{R}$ - interatomic distance, $\sigma^{2}$ - Debye-Waller factor, $\Delta \mathrm{E}_{0}$ - energy shift, R factor - goodness of fit) for the CysCys(2)-Ca $\mathrm{Fe}_{-}$ LDH sample

\begin{tabular}{lllllll}
\hline Sample & $(\mathrm{Fe}-) \mathrm{X}$ & $\mathrm{N}$ & $\mathrm{R}(\AA)$ & $\sigma^{2}\left(\AA^{2}\right)$ & $\Delta \mathrm{E}_{0}(\mathrm{eV})$ & $\mathrm{R}$ factor \\
\hline CysCysFe-LDH & $\mathrm{O}$ & 6 & 1.99 & 0.0071 & -4.69 & 0.0201 \\
& $\mathrm{Ca}$ & 3 & 3.12 & 0.0089 & & \\
& $\mathrm{Ca}$ & 3 & 3.54 & 0.0090 & &
\end{tabular}

The SEM images (Figure 51) show that the quality of particles in the samples is lower than in the previous sample; nevertheless, the LDH-like morphology is still recognizable. The elemental maps (Figure 52) verify the presence of the iron, calcium, carbon and sulfur too, and the uniform distribution of the elements within the particles. 
Although it is certain that intercalation of the cystinate anions did occur (the first reflection shifted toward lower $2 \theta$ values); however, the morphologies of the CysCys(2)CaFe-LDH sample and and Na-cystinate are not very different any more (compare Figure 51 and Figure 48), indicating that the part of the cystinate ions was attached to the outer surface of the LDH.

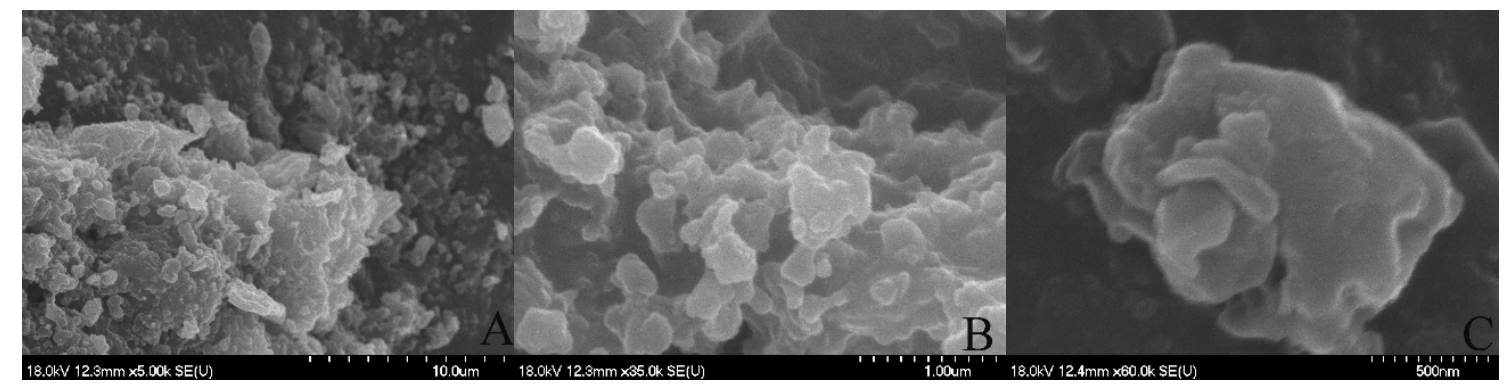

Figure 51. SEM images of the CysCys(2)-Ca2Fe-LDH sample (CysCys:Fe = 2); magnifications: 6,000 (A), $30,000(B)$ and $60,000(C)$

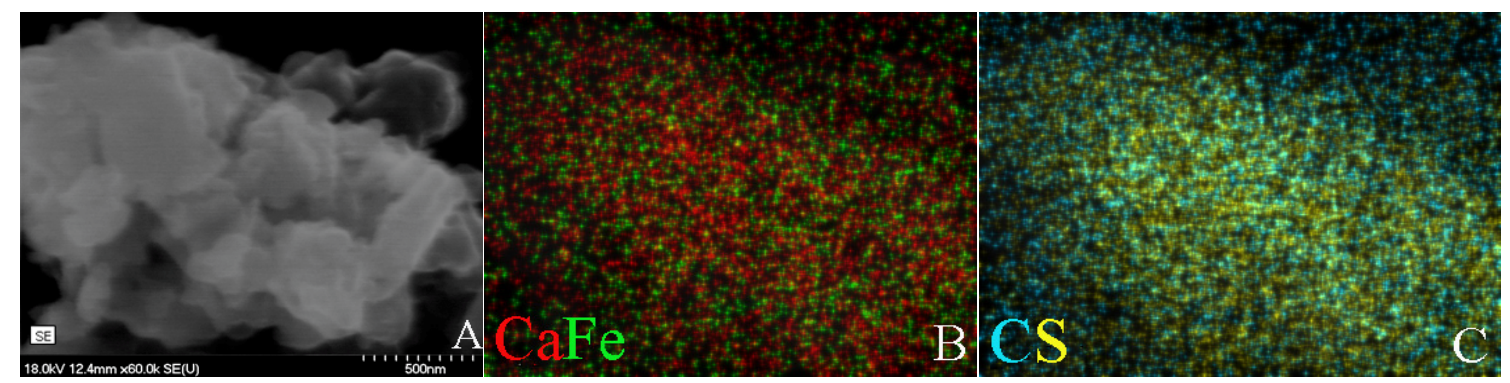

Figure 52. Ca-Fe (B) and C-S (C) elemental distribution maps on the CysCys(2)-Ca2 $\mathrm{Fe}-\mathrm{LDH}$ sample (A) at magnification of 60,000

This is also indicated by the FT-IR spectrum of the CysCys(2)-CaFe-LDH (Figure 53 , spectrum B) - it is very rich in intense bands resembling those of Na-cystinate (Figure 53, spectrum C).

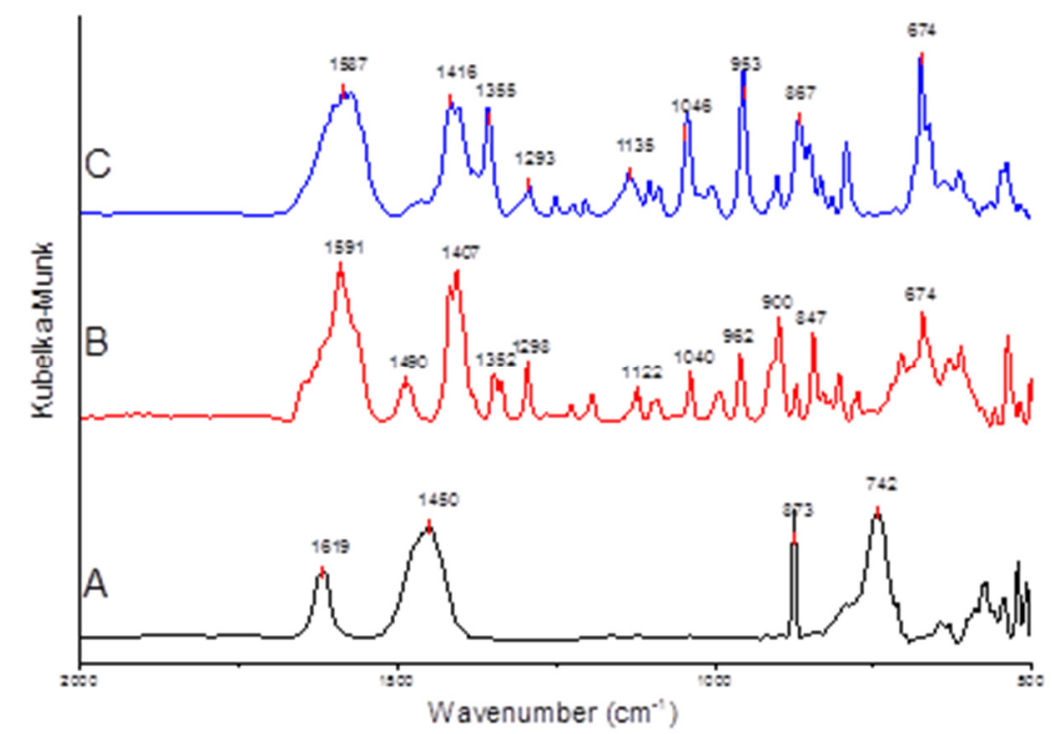

Figure 53. The FT-IR spectra of the pristine CaFe-LDH (A), the CysCys(2)-Ca2 Fe-LDH (B) and the Nacystinate $(\mathrm{C})$ 
In the following set of experiments, instead of the Na-cystine solution, precipitated Na-cystinate salt and water were added in the wet milling step (Method 3). Under these circumstances no, LDH was formed as the X-ray diffractograms (Figure 54) attest.

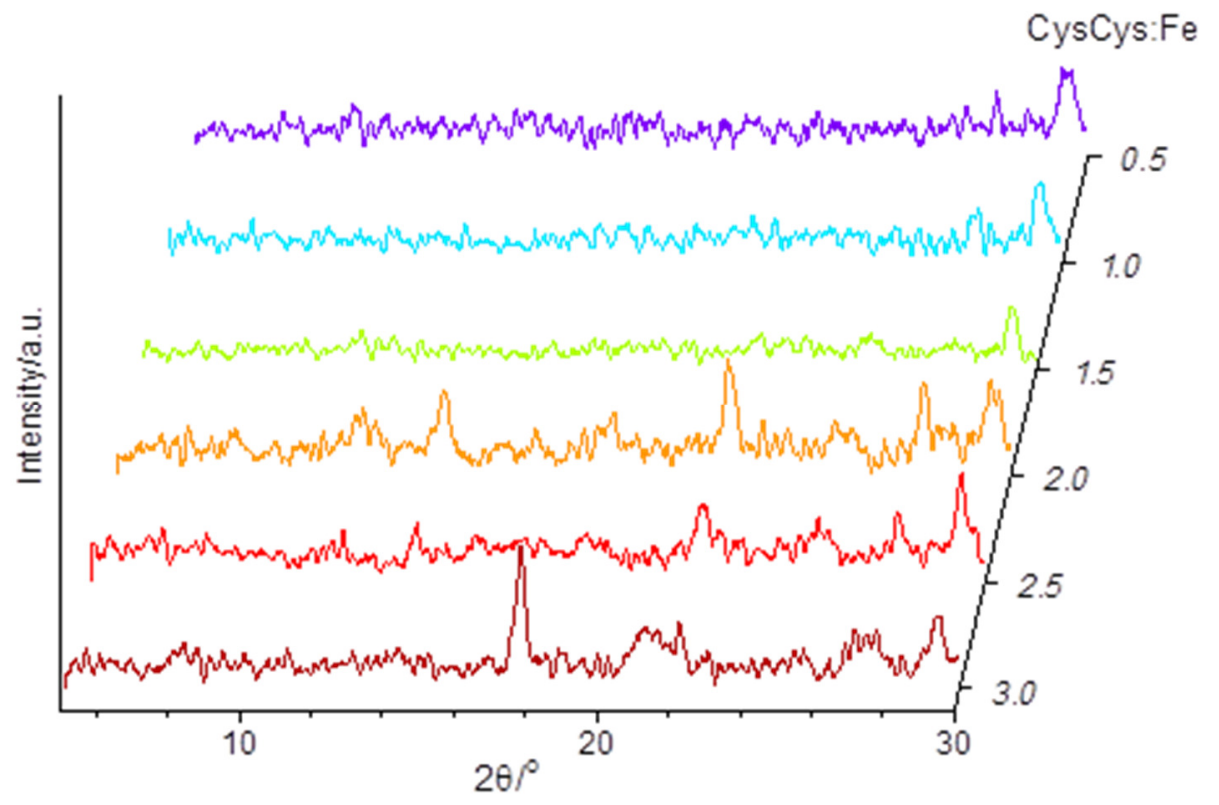

Figure 54. X-ray diffractograms of the $\mathrm{Ca}_{2} \mathrm{Fe}$ samples treated with $\mathrm{Na}$-cystinate salt and water at varying CysCys:Fe ratios

Using the Bragg equation and the position of the first basal reflection (003), the interlayer distances were calculated for the optimized pristine LDH as well as for the cystinate-containing samples chosen and described above.

Table 12. The interlayer distances of the cystinate-containing samples

\begin{tabular}{cccc}
\hline LDH sample & $\begin{array}{c}\text { Position of the }(003) \\
\text { reflection }\left(2 \theta /{ }^{\circ}\right)\end{array}$ & $\begin{array}{c}\text { do03 } \\
(\AA)\end{array}$ & $\begin{array}{c}\text { Interlayer } \\
\text { distance }(\AA)\end{array}$ \\
\hline CaFe- & 11.2 & 7.93 & 6.15 \\
CysCys(1.5)-CaFe- & 8.1 & 10.90 & 9.12 \\
CysCys(2)-CaFe- & 8.5 & 10.40 & 8.62 \\
\hline
\end{tabular}

*The thickness of one layer is $1.78 \AA$ by XRD measurements ${ }^{[15]}$

Since the cystinate anion may be included in a $11.22 \times 4.63 \times 3.36$ (obtained after geometry optimization at the PM3 semiempirical level[156] [157]; dimensions are given in $\AA$ ) prism, it is situated between the layers in a horizontal, double-layer manner, nearly parallel to the layers (Figure 55). 


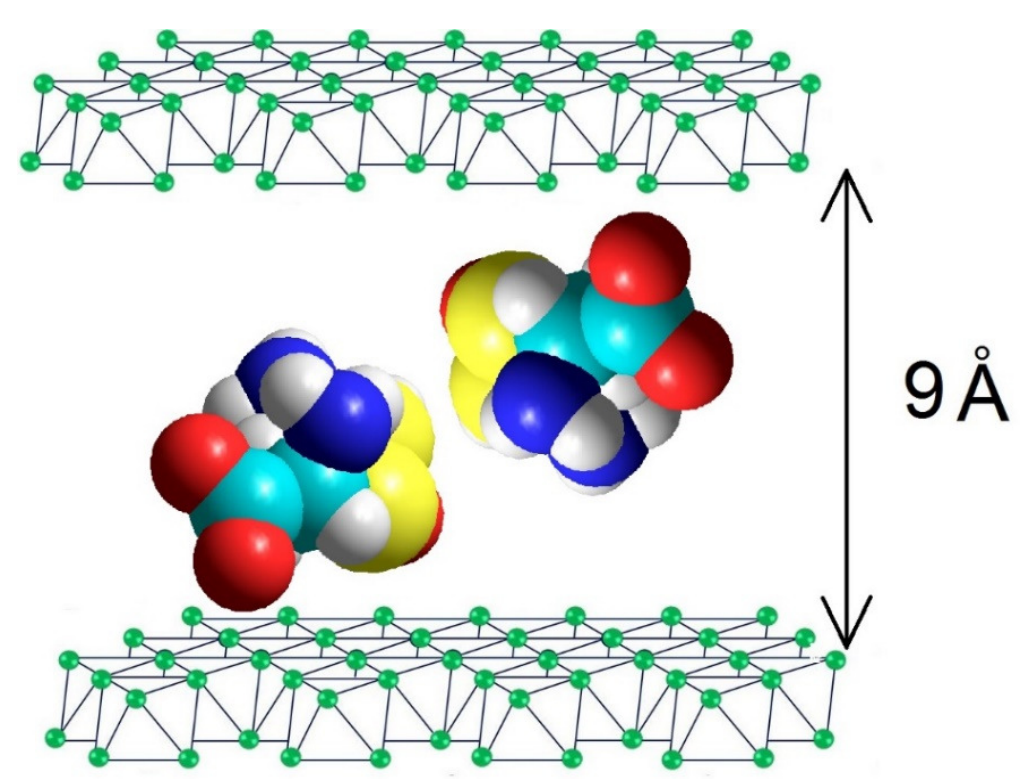

Figure 55. The orientation of the cystinate within the CaFe-LDH layers

\subsubsection{L-Tyrosine}

In an analogous way to that used for cystine, the intercalation of the anionic form of tyrosine was also attempted.

The first parameter to be examined was the amount of added $3 \mathrm{M} \mathrm{NaOH}$ (Figure $56)$.

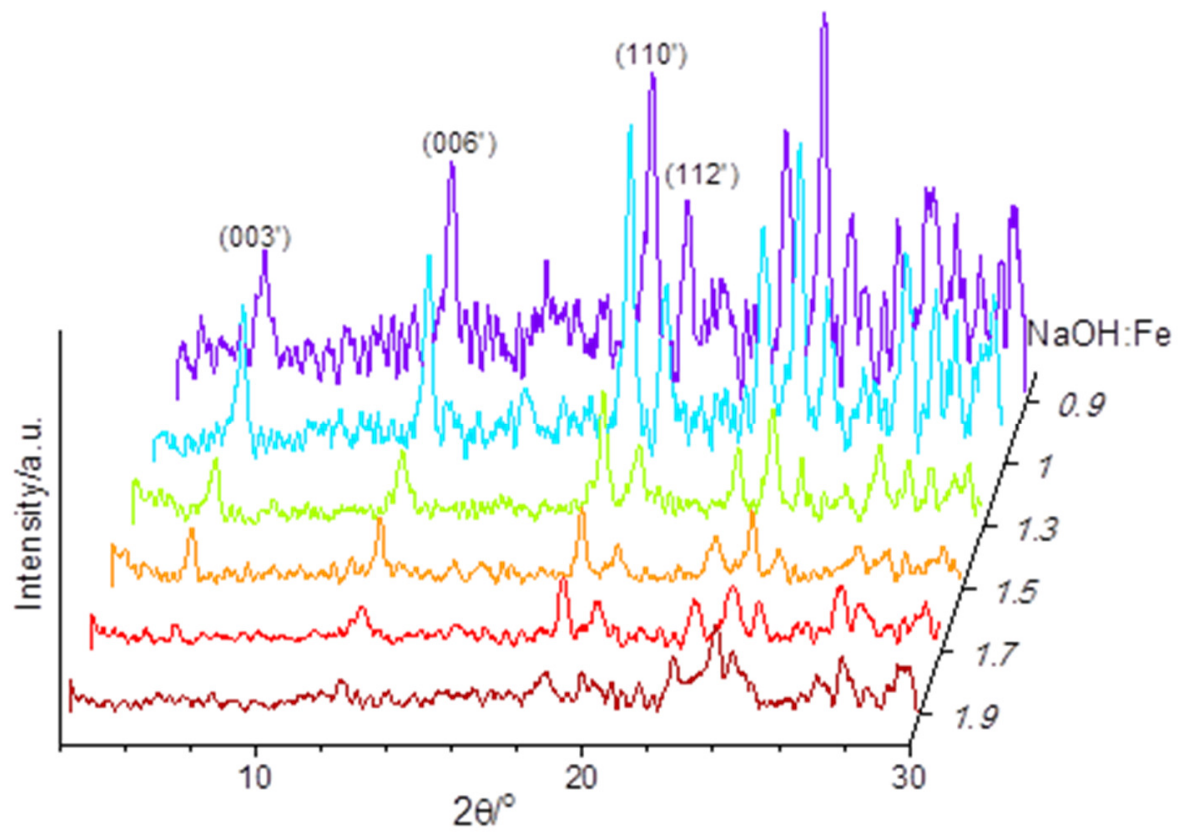

Figure 56. X-ray diffractograms of the tyrosinate-intercalated $\mathrm{Ca}_{2} \mathrm{Fe}$ samples, with the systematic change of the $\mathrm{NaOH}: \mathrm{Fe}$ molar ratio (Tyr:Fe $=1: 1$ )

LDH formation could be observed at most NaOH:Fe ratios examined; however, the sharpest and most intense reflections were produced by the sample having $\mathrm{NaOH}: \mathrm{Fe}=1$ molar ratio. For further optimization through the systematic change of the Tyr:Fe ratio, 
samples with this NaOH:Fe ratio were chosen (Method 1). Now, the aim was to find the optimal Tyr:Fe ratio. This ratio was changed in a wide range, from 0.5 to 5 (Figure 57).

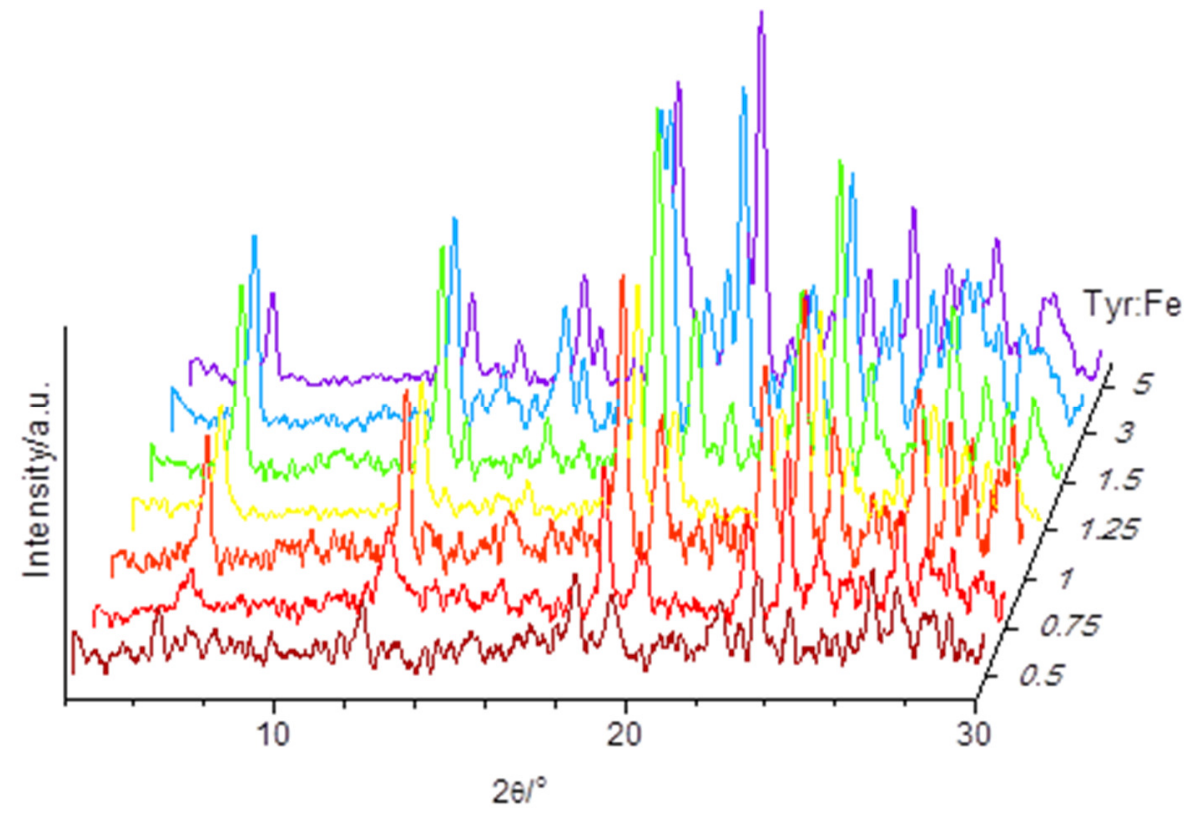

Figure 57. X-ray diffractograms of the tyrosinate-intercalated Ca2Fe samples with the systematic change of the Tyr:Fe molar ratio at $\mathrm{NaOH}: \mathrm{Fe}=1$

At low amount of Tyr, the reflections of the tyrosinate-intercalated LDH were wide with low intensities. (It is to be noted that the reflections of intercalated, but not the pristine LDH are seen at each ratio). Increasing the amount of tyrosine, the reflections became sharper and more intense reaching their maximum around ratios of 1.5-3, after which the intensities decreased. (It is to be noted that at high ratios, above1.5, the reflections of L-tyrosine may also appear due to its large excess). The decrease in the intensities is caused by the small amount of mechanical energy per unit transmitted, due to increased sample mass. For further characterization, the sample with Tyr:Fe $=1$ (Tyr(1)-CaFe-LDH in the followings) was chosen. The SEM images (Figure 58) represent the typical morphology of the LDHs, showing lamellar structure and hexagonally-shaped particles.

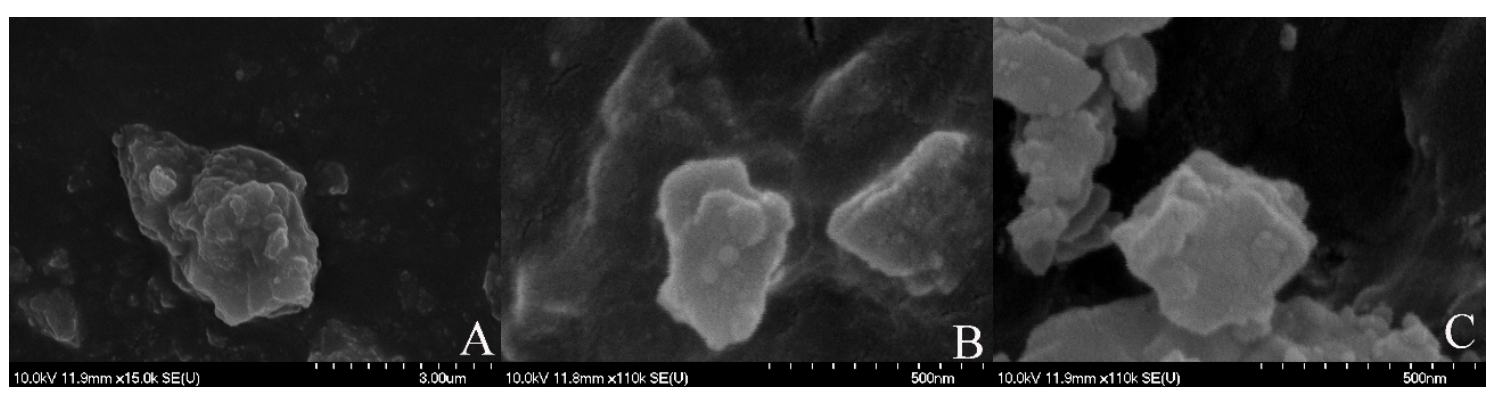

Figure 58. SEM images of the Tyr(1.5)-Ca2Fe-LDH sample (Tyr:Fe = 1.5); magnifica-tions: 15,000 (A), $110,000(B)$ and $110,000(C)$ 


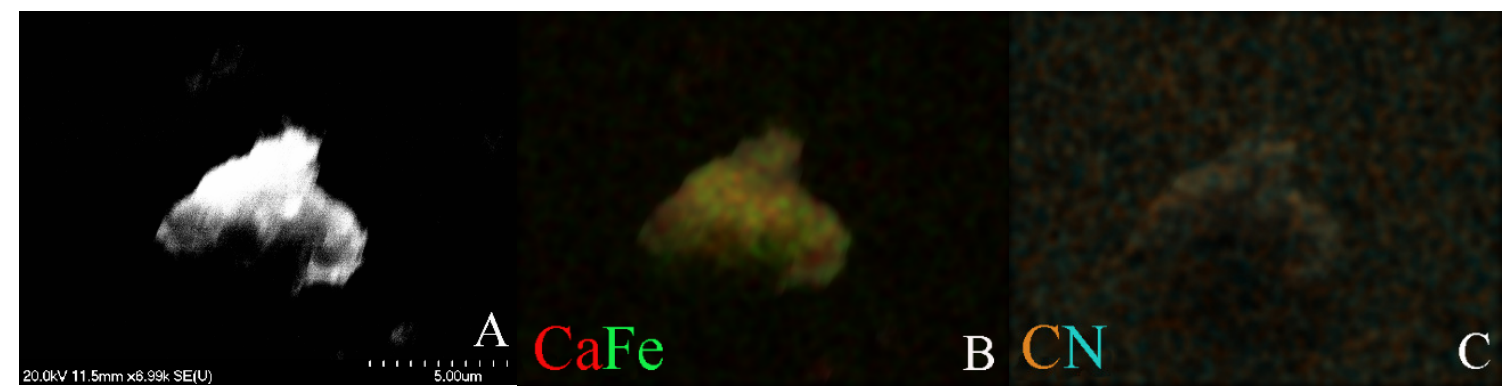

Figure 59. Ca-Fe (B) and C-N (C) elemental distribution maps on the Tyr(1.5)-Ca 2 Fe-LDH sample (A) at a magnification of 6,990

The SEM-EDX elemental maps (Figure 59) verify the presence of calcium and iron as well as carbon and nitrogen. Their distribution is uniform; no segregation or aggregation can be noticed.

Next, a saturated solution of tyrosine (1.4 M concentration) and $3 \mathrm{M} \mathrm{NaOH}$ was prepared and used in the wet-milling step (Method 2). The Tyr:Fe ratio was varied from 0.5 to 3 (Figure 60).

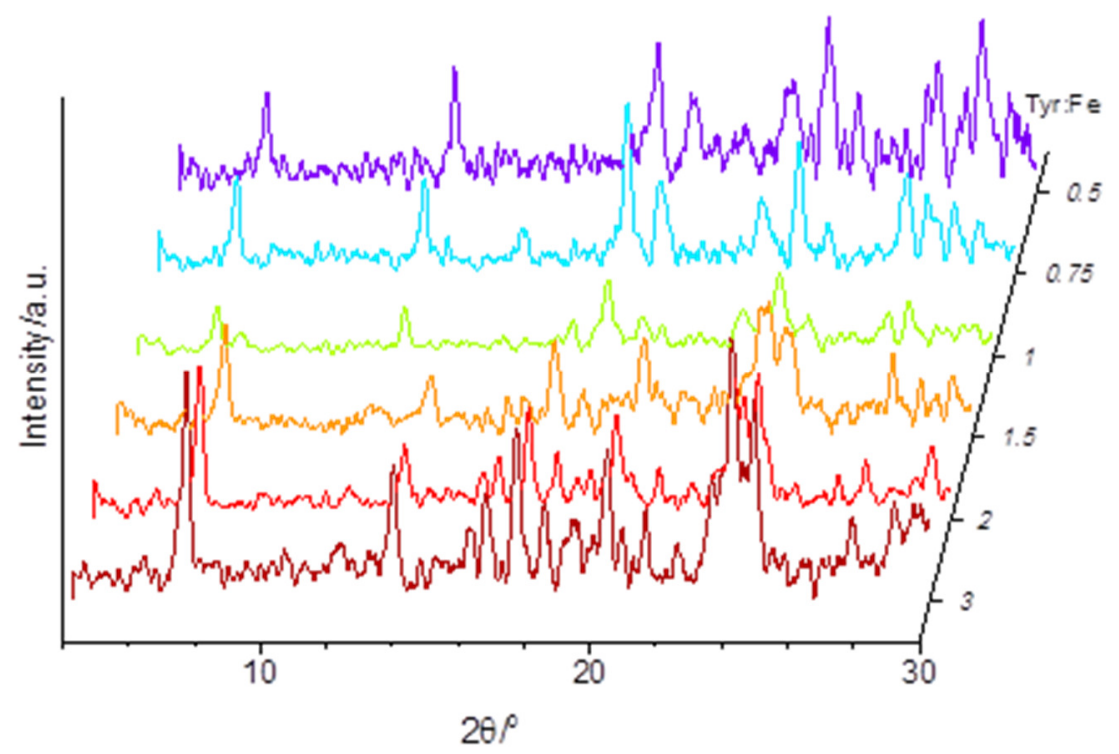

Figure 60. X-ray diffractograms of the tyrosine intercalated $\mathrm{Ca}_{2} \mathrm{Fe}$ samples with the systematic change of the Tyr:Fe molar ratio using saturated tyrosine (concentration $1.4 \mathrm{M}$ ) and excess $3 \mathrm{M} \mathrm{NaOH}$ solutions

In all the samples, the positions of the major reflections, especially of the first ones, verify that the intercalation of the tyrosinate ions readily occurred. The $\operatorname{Tyr}(3)-\mathrm{CaFe}-$ LDH sample, having the highest intensities, was selected for further characterization with SEM (Figure 61), SEM-EDX (Figure 62) and IR (Figure 66) measurements. This sample, due to excess tyrosinate ions, probably contained tyrosinate adsorbed on the outer surface of the $\mathrm{LDH}$, and, thus, its reflection may also appear at higher2 $\theta$ degrees. 


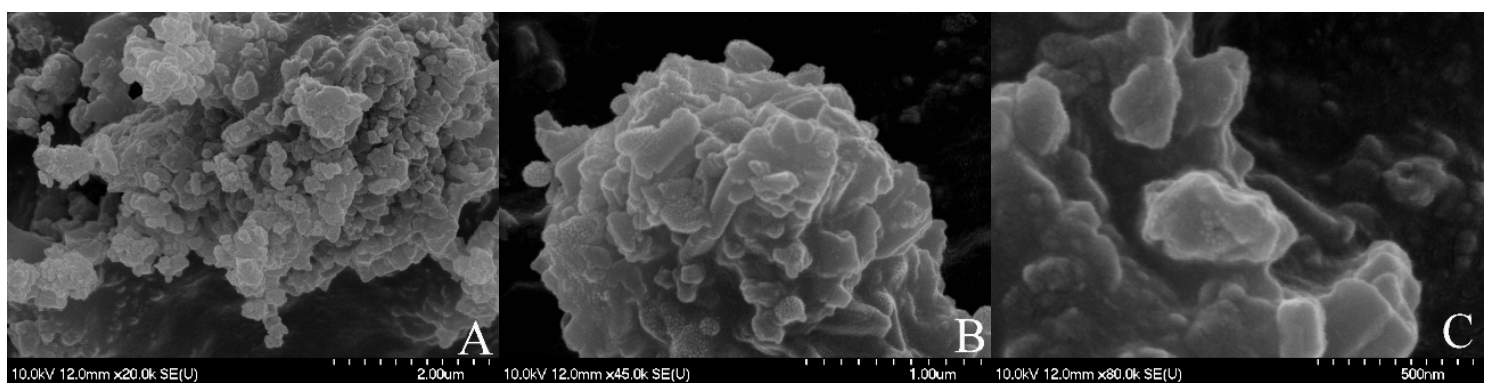

Figure 61. SEM images of the Tyr(3)-Ca2Fe-LDH (Tyr:Fe = 3); magnifications: 20,000 (A), 45,000(B) and $90,000(\mathrm{C})$

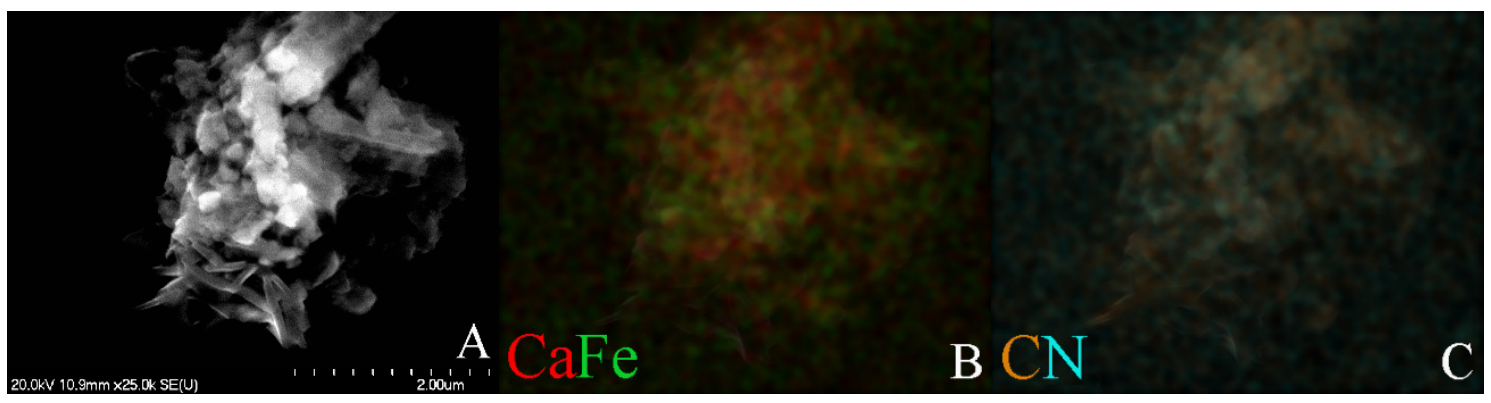

Figure 62. Ca-Fe (B) and C-N (C) elemental distribution maps of the Tyr(3)-Ca2Fe-LDH sample (A) at magnification of 20,000

The SEM images (Figure 61) revealed the typical morphology of the LDHs. Hexagonally-shaped particles were revealed in the SEM images, and the SEM-EDX maps (Figure 62) showed the presence of iron and calcium as well as carbon and nitrogen in the samples.

Finally, the synthesis was performed using solid Na-tyrosinate as well (Method 3). The Tyr:Fe molar ratio was varied from 0.5 to 3. The X-ray diffractograms (Figure 63) indicated again the success of intercalation at each ratio studied. Just as in the previous experiments, the shifts of the major reflections towards lower angles clearly indicated that the interlayer distance increased, and there was no reflection typical of the pristine $\mathrm{LDH}$, i.e., the intercalation of the tyrosinate ions was successful. The most intense and the sharpest reflections were identified in the Tyr(2)-CaFe-LDH sample (Tyr:Fe molar ratio was 2), and this was chosen for further structural characterization.

The SEM images (Figure 64) and the SEM-EDX elemental maps (Figure 65), just as in the previous instance revealed the characteristics of intercalated LDHs (hexagonallyshaped disc-like particles, close to even distribution of iron, calcium, carbon and nitrogen). 


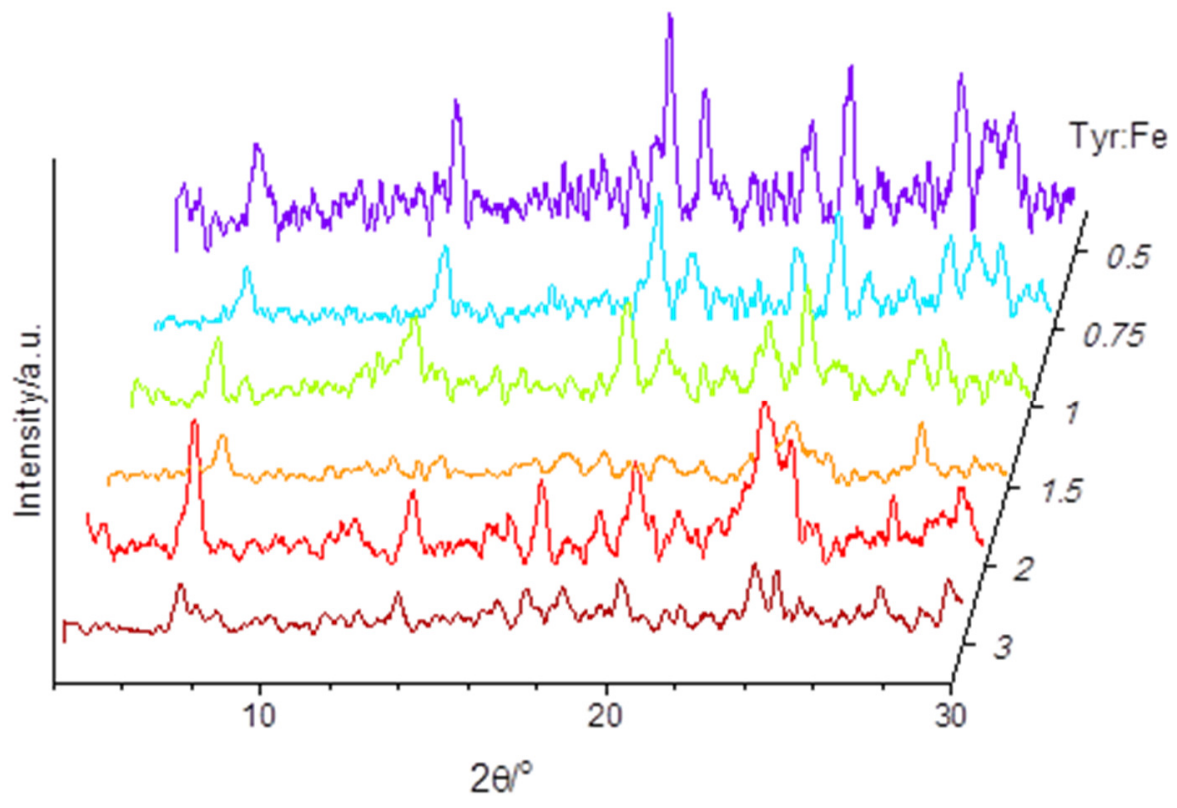

Figure 63. X-ray diffractograms of the tyrosinate-intercalated $\mathrm{Ca}_{2} \mathrm{Fe}$ samples with the systematic change of the Tyr:Fe molar ratio using solid Na-tyrosine salt and water

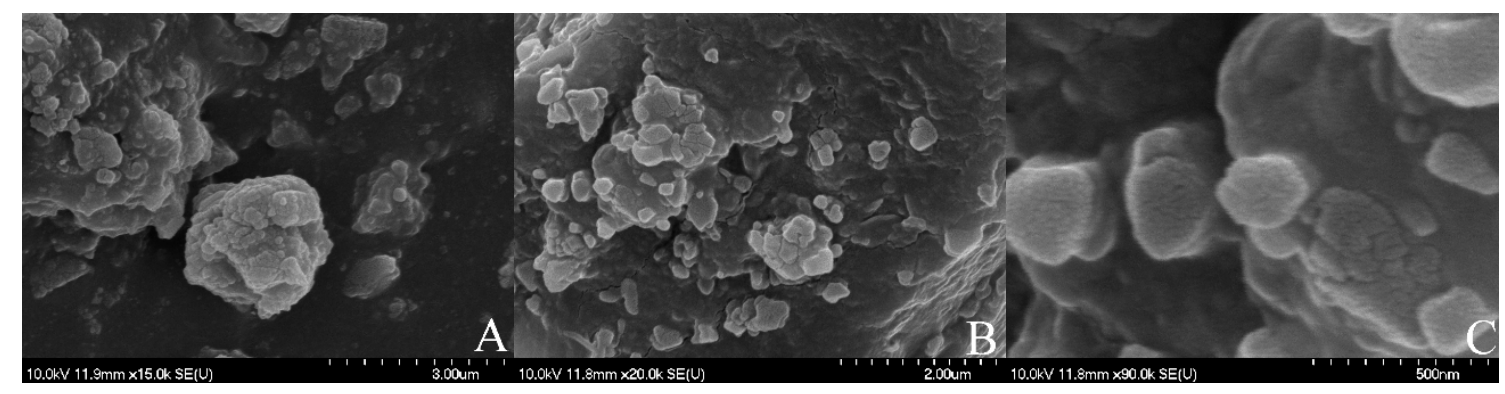

Figure 64. SEM images of the Tyr(2)-Ca2Fe-LDH sample (Tyr:Fe = 2), magnifications: 15,000 (A), $20,000(B)$ and $90,000(C)$

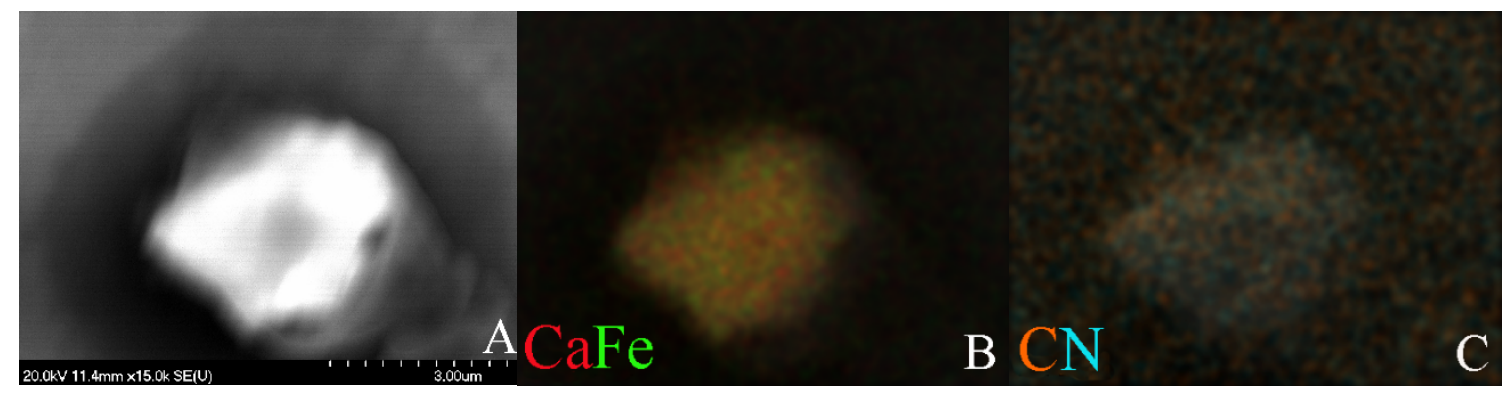

Figure 65. Ca-Fe (B) and C-N (C) elemental distribution maps on the Tyr(2)-Ca2Fe-LDH sample (A) at magnification of 15,000

FT-IR spectra of these last two selected samples were also registered (Figure 66 and Figure 67). The findings are basically the same, and it is detailed using the solid Natyrosinate-intercalated sample (Figure 67) as the example. 


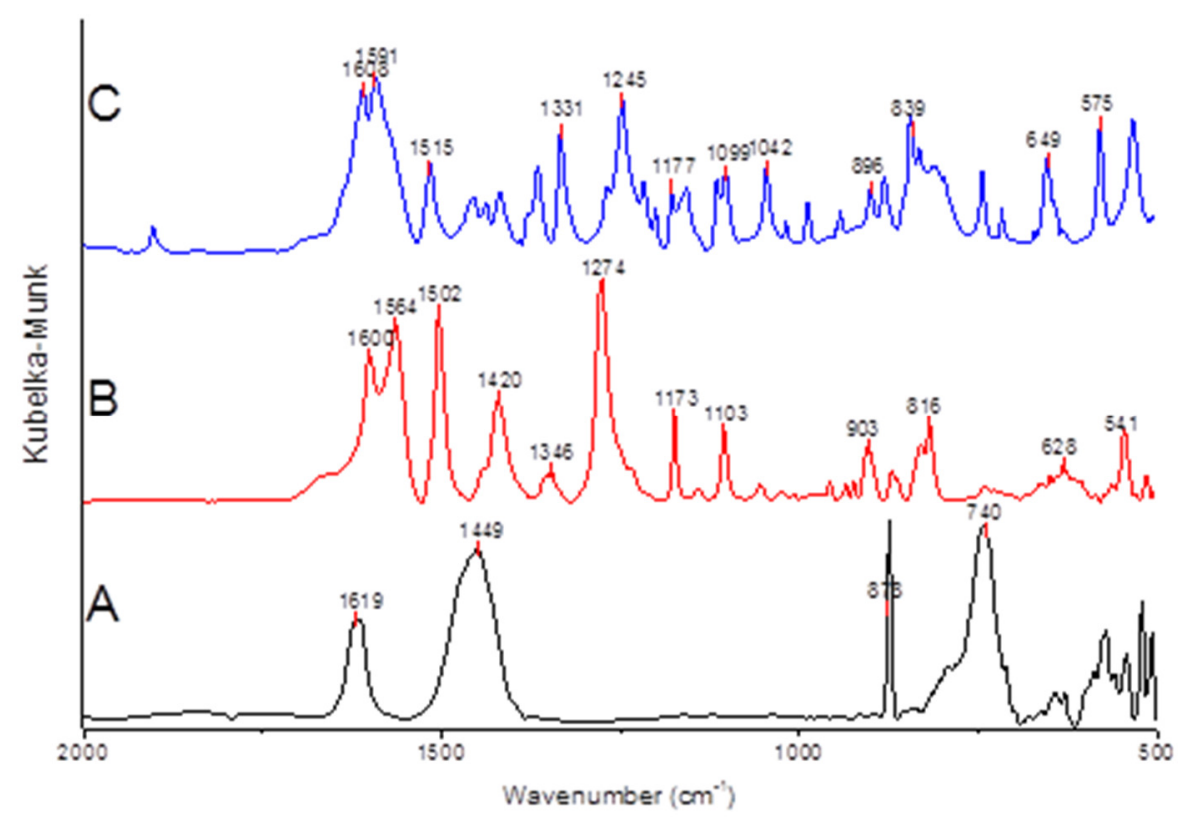

Figure 66. The FT-IR spectra of the pristine Ca2Fe-LDH (A), the Tyr(3)-Ca2Fe-LDH sample (B) and Natyrosinate $(\mathrm{C})$

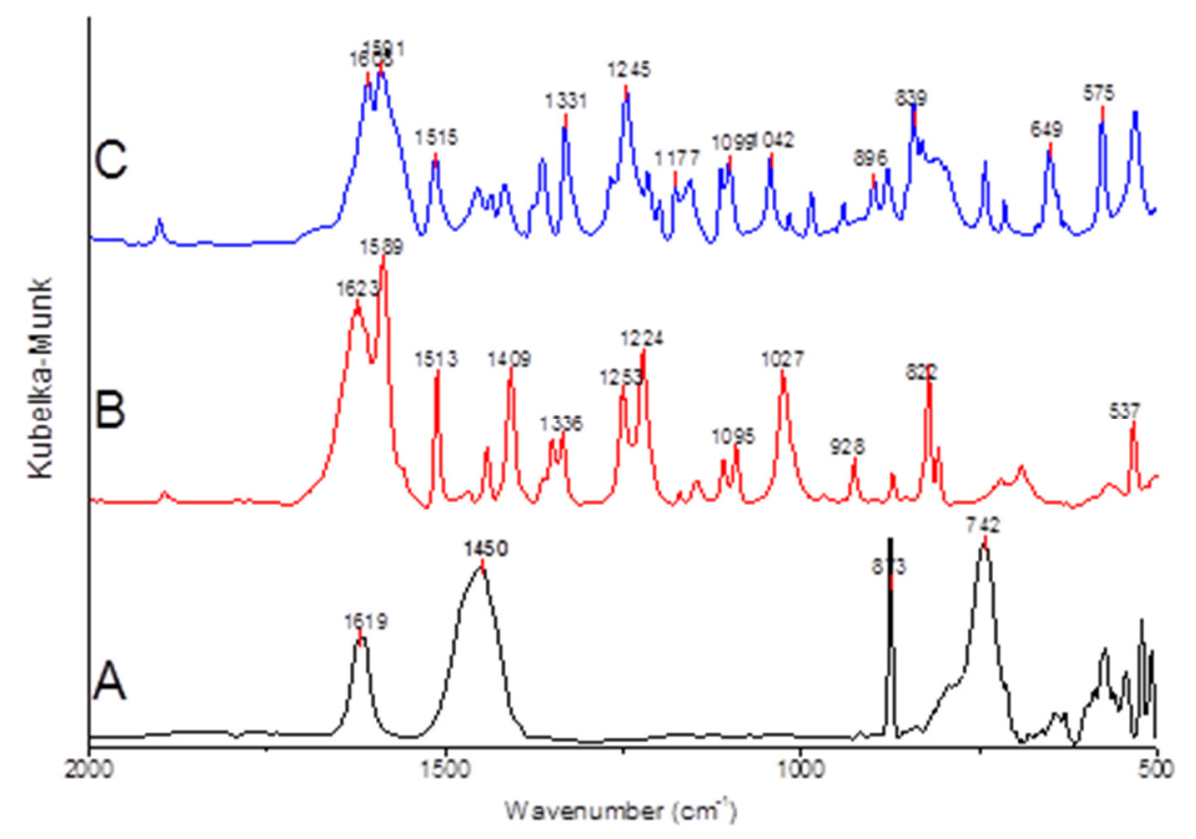

Figure 67. The FT-IR spectra of the pristine CaFe-LDH (A), the Tyr(2)-CaFe-LDH sample (B) and Natyrosinate $(\mathrm{C})$

The spectra displayed in the figure revealed the typical vibrations of the tyrosinate in the tyrosinate-containing sample: $\mathrm{C}-\mathrm{N}$ bond $\left(1336 \mathrm{~cm}^{-1}\right), \mathrm{N}-\mathrm{H}$ bond $\left(1589 \mathrm{~cm}^{-1}\right)$, carboxylate group (1623 $\mathrm{cm}^{-1}$ and $\left.1409 \mathrm{~cm}^{-1}\right)$, aromatic ring $\left(1513 \mathrm{~cm}^{-1}\right)$ as well as vibrations $0-$ metal-0 bonds of the pristine LDH under $1000 \mathrm{~cm}^{-1}\left(875 \mathrm{~cm}^{-1}\right)$. Some of the vibrations of the tyrosine shifted compared to those of Na-tyrosinate, like the asymmetric stretching vibration of the carboxylate group (from $1608 \mathrm{~cm}^{-1}$ to $1623 \mathrm{~cm}^{-1}$ ) 
the $\mathrm{C}-\mathrm{O}$ vibration (from $1245 \mathrm{~cm}^{-1}$ to $1253 \mathrm{~cm}^{-1}$ ), suggesting that the amino acid was between the layers.

Similarly, to the cystinate-intercalated sample, X-ray absorption measurements indicated that the layers of the host remained unchanged during the intercalation of the tyrosinate ion (Figure 68 and Table 13).
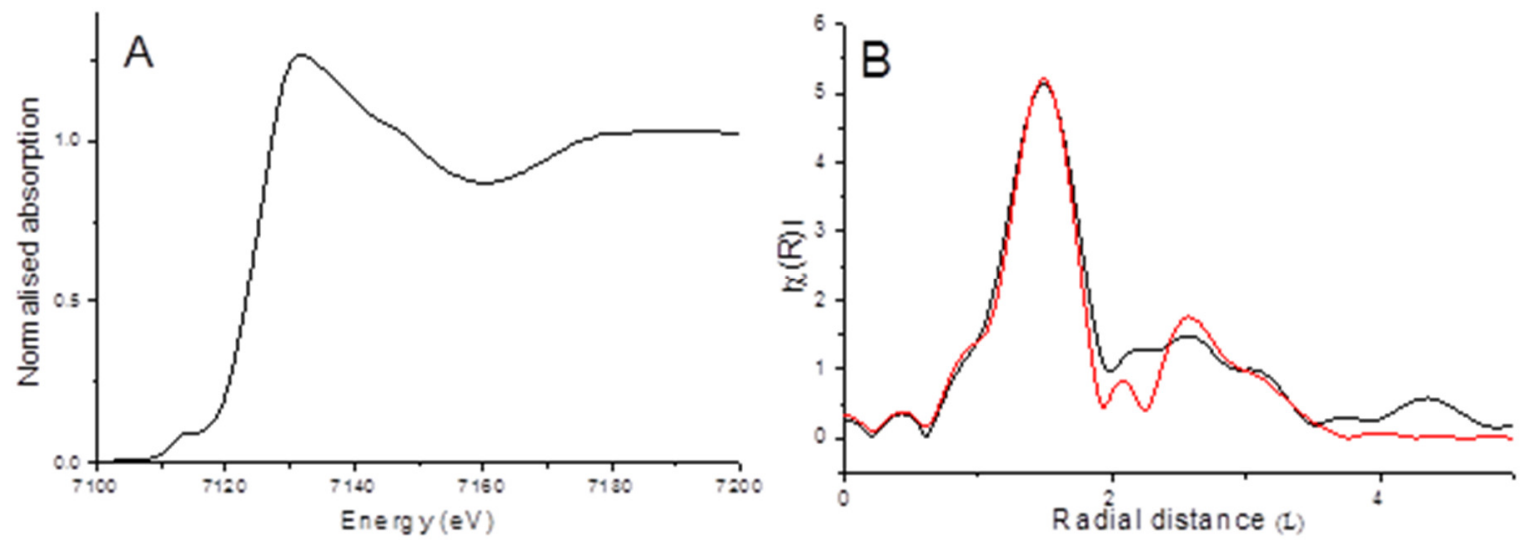

Figure 68. X-ray absorption spectrum at the near-edge region (a) and the Fourier-transformed EXAFS data (without phase correction; red line - fit, black line - experimental) of the Tyr(2)-Ca2Fe-LDH sample

Table 13. Parameters deduced from the fitted EXAFS spectrum ( $\mathrm{N}$ - coordination number, $\mathrm{R}$ - interatomic distance, $\sigma^{2}$ - Debye-Waller factor, $\Delta \mathrm{E}_{0}$ - energy shift, $\mathrm{R}$ factor - goodness of fit) for Tyr(2)-Ca2Fe-LDH

\begin{tabular}{ccccccc}
\hline Sample & $(\mathrm{Fe}-) \mathrm{X}$ & $\mathrm{N}$ & $\mathrm{R}(\AA)$ & $\sigma^{2}\left(\AA^{2}\right)$ & $\Delta \mathrm{E}_{0}(\mathrm{eV})$ & $\mathrm{R}$ factor \\
\hline TyrFe-LDH & $\mathrm{O}$ & 6 & 1.98 & 0.0066 & -4.87 & 0.0222 \\
& $\mathrm{Ca}$ & 3 & 3.12 & 0.0108 & & \\
& $\mathrm{Ca}$ & 3 & 3.54 & 0.0105 & &
\end{tabular}

Using the Bragg equation and the positions of the first basal reflections, the interlayer distances were calculated for each selected tyrosine-containing sample (Table $14)$.

Table 14. The interlayer distances of the tyrosinate-containing samples

\begin{tabular}{cccc}
\hline LDH sample & $\begin{array}{c}\text { Position of the }(003) \\
\text { reflection } \\
\left(2 \theta /{ }^{\circ}\right)\end{array}$ & $\begin{array}{c}\text { do03 } \\
(\AA)\end{array}$ & $\begin{array}{c}\text { Interlayer } \\
\text { distance }(\AA)^{*}\end{array}$ \\
\hline CaFe- & 11.2 & 7.93 & 6.11 \\
Tyr(1.5)-CaFe- & 6.5 & 13.56 & 11.78 \\
Tyr(3)-CaFe- & 7.4 & 11.19 & 9.41 \\
Tyr(2)-CaFe- & 7.1 & 12.47 & 10.69 \\
\hline
\end{tabular}

${ }^{*}$ The thickness of one layer is $1.78 \AA$ by XRD measurements ${ }^{[15]}$ 
From these calculated interlayer spaces, the position of the tyrosinate ion may be suggested knowing that the tyrosinate ion can be included in a prism of $7.7 \times 4.18 \times 4.28$ (obtained after geometry optimization at the PM3 semiempirical level [156] [157]; dimensions are given in $\AA$ ). The tyrosinate ion can conveniently fit in perpendicular manner in to each intercalated sample (Figure 69); however, a horizontal double-layer arrangement, when the anions are situated close to parallel with the layers of the LDHs (Figure 70), is equally feasible.

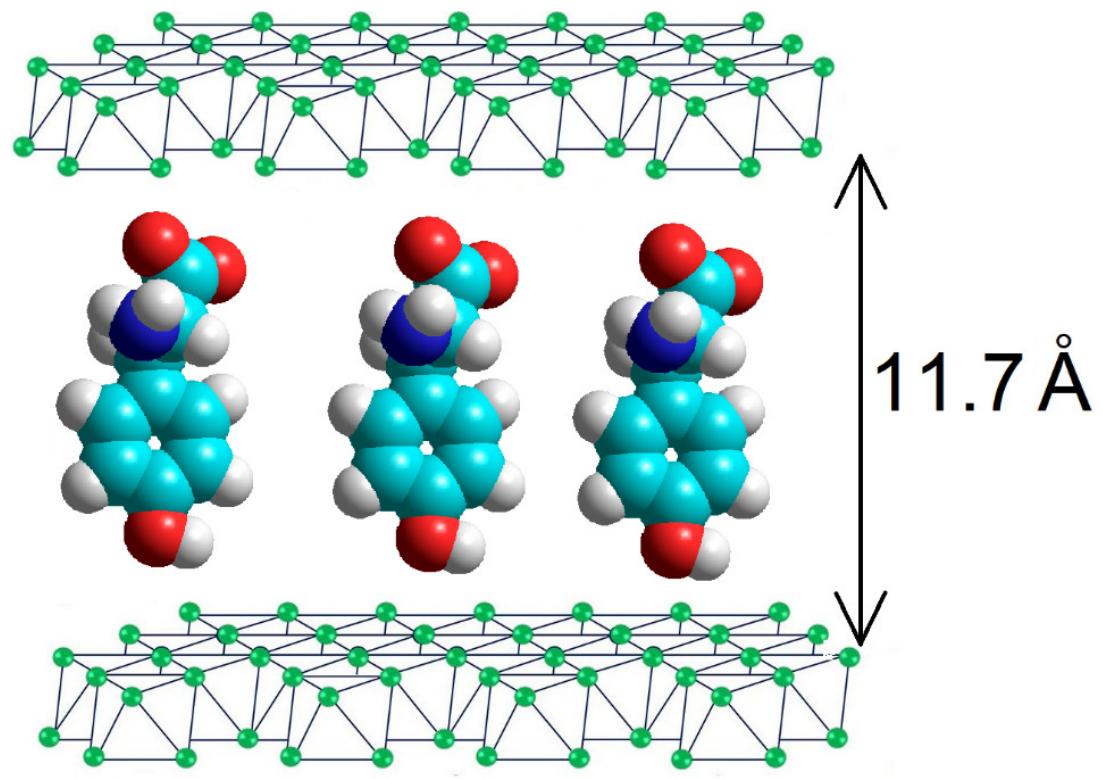

Figure 69. The perpendicular orientation of the tyrosine within the CaFe-LDH layers

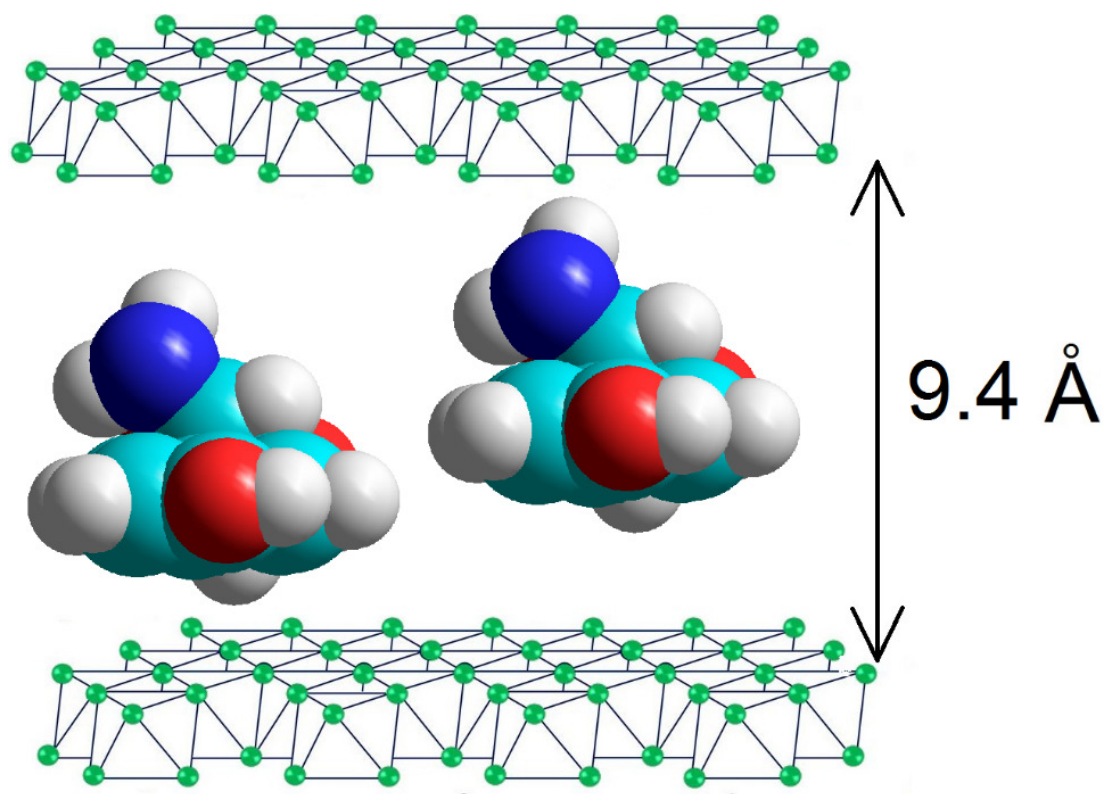

Figure 70. The horizontal, double layer orientation of the tyrosine within the CaFe-LDH layers

The intercalation of various amino acid anions (cystinate and tyrosinate) was attempted with the slightly modified two-step grinding procedure, and the optimization 
of the intercalation reactions were also performed. It was revealed that the tyrosinate ion was readily intercalated, while the formation of inorganic anion-intercalated LDH (called pristine LDH) always competed with that of the cystinate-intercalated LDH.

On the basis of calculating the interlayer distances for the organically intercalated LDHs and the knowledge of the dimensions the amino acid anions, it was revealed that the cystinate anions could be accommodated in a double-layer manner, in which the anions lay parallel with the layers; the tyrosinate ions can behave similarly, although a single-layer, perpendicularly oriented arrangement can also be an option. 


\section{CONCLUSIONS}

Layered double hydroxides (LDHs) represent a unique group of clays exhibiting anion exchange capabilities. Structurally, they consist of positively-charged mixed-metal layers, in order to achieve charge neutrality, charge-compensating anions and water molecules are situated between the layers. These composite materials can be found in Nature, but they can be also synthesized. The traditional methods for their synthesis are solution based methods.

During the experimental work leading to this dissertation, a less widely used method was chosen for the preparation and intercalation of CaSn-, CaAl- and CaFe-LDHs, mechanochemistry that is. The synthesized materials were extensively characterized by various methods like X-ray diffractometry (XRD), infrared spectroscopy (IR), thermogravimetric analysis (TG/dTG), near edge X-ray absorption fine structure spectroscopies (EXAFS) and scanning electron microscopies and scanning electron microscopy coupled with energy dispersive X-ray spectroscopy (SEM, SEM-EDX).

It has been demonstrated that mechanochemistry is a viable option in the synthesis of the LDHs; furthermore, for the Ca(II)Sn(IV) system it has been proven that using mechanochemistry even those LDHs can be synthesized, for which the classical solution-based methods failed. With the synthesis of this LDH it was proven that an LDH could be synthesized, which contained Sn(IV) in its layers (which was quite controversial in the literature). The two-step milling operation was further optimized using the $\mathrm{Ca}(\mathrm{II}) \mathrm{Al}(\mathrm{III})$ and $\mathrm{Ca}(\mathrm{II}) \mathrm{Fe}(\mathrm{III})$ systems. For both cases, the optimal reaction conditions have been determined (by systematically varying the parameters of the experiments), under which nearly phase-pure materials could be prepared (with a near complete conversion of the precursors). It has been revealed that the addition of water is of utmost importance, and also that the major parameter is the extended mechanical energy, i.e., the ball/sample ratio. In all cases, the XRD patterns for the synthesized LDHs exhibited characteristic features indicative of an ordered layered material. The TG measurements, the SEM and SEM-EDX images show the characteristic features of the LDHs. The EXAFS data for the $\mathrm{Ca}(\mathrm{II}) \mathrm{Fe}(\mathrm{III})$ system, show that in the first coordination shell of the Fe there are six oxygen atoms with $1.99 \AA \AA \mathrm{Fe}-\mathrm{O}$ interatomic distance, with the second coordination sphere containing three $\mathrm{Ca}^{2+}$ ions with $3.12 \AA \mathrm{Fe}-\mathrm{Ca}$ 
interatomic distance and three other $\mathrm{Ca}^{2+}$ atoms having $3.55 \AA$ as $\mathrm{Fe}-\mathrm{Ca}$ interatomic distance. These are also characteristic to LDHs.

The intercalation of different amino acids (cystine, tyrosine and valine) was attempted via mechanochemistry in different LDHs (CaSn and CaFe). For the $\mathrm{Ca}(\mathrm{II}) \mathrm{Sn}(\mathrm{IV})$ system it was evidenced that the intercalation of the amino acid anions can be achieved using mechanochemistry. Using the Ca(II)Fe(III) system with a slightly modified two-step grinding procedure, the optimization of the intercalation reactions was performed. It was revealed that the formation of the cystinate-intercalated LDH competed with the inorganic anion-intercalated LDHs formation, while the tyrosinate ions readily intercalated in the LDHs. The XRD confirms the intercalation as the IR, SEM and SEM-EDX measurements do. The X-ray absorption data show the characteristics of LDHs, meaning the LDH layers were not harmed during intercalation. Given the dimensions of the amino acid anions, and the calculated interlayer distances of the intercalated LDHs a presumption on the orientation of the amino acid anions could be given. The cystinate anions could be accommodated in a double-layer manner, in which the anions lay parallel with the layers; the tyrosinate ions can behave similarly, although a single-layer, perpendicularly oriented arrangement can also be an option.

These results clearly attest that mechanochemistry is an applicable option in the synthesis and intercalation of layered double hydroxides. With the optimization of the reaction parameters nearly phase pure LDHs can be synthesized, and the intercalation of different amino acid anions can be achieved. It has also been demonstrated; that via using this technique, even more "exotic" LDHs can be prepared, for which the synthesis was not possible using traditional solution based methods. 


\section{REFERENCES}

[1] W. Feitknecht, Helvetica Chimica Acta 1942, 25, 13-137.

[2] J. B. Parise, K. Leinenweber, D. J. Weidner and K. Tan, American Mineralogist 1994, 79, 193-196.

[3] S. J. Mills, A. G. Christy, J. M. R. Génin, T. Kameda and F. Colombo, Mineralogical Magazine 2012, 76, 1289-1336.

[4] D. G. Evans and R. C. T. Slade in Structural Aspects of Layered Double Hydroxides, Vol. 2005.

[5] A. I. Khan and D. O'Hare, Journal of Materials Chemistry 2002, 12, 3191-3198.

[6] D. Srankó, A. Pallagi, E. Kuzmann, S. E. Canton, M. Walczak, A. Sápi, Á. Kukovecz, Z. Kónya, P. Sipos and I. Pálinkó, Applied Clay Science 2010, 48, 214-217.

[7] H. Curtius, K. Ufer and K. Dardenne, Radiochimica Acta 2009, 97, 423-428.

[8] 0. T. Saber, H., Journal of Porous Materials 2003, 10, 83-91.

[9] M.-C. Lin, F.-T. Chang and J.-Y. Uan, Journal of Materials Chemistry 2010, 20, 65246530.

[10] F. Cavani, F. Trifiró and A. Vaccari, Catalysis Today 1991, 11, 173-301.

[11] M. Vucelic, W. Jones and G. D. Moggridge, Clays and Clay Minerals 1997, 45, 803813.

[12] M. Catti, G. Ferraris, S. Hull and A. Pavese, Physics and Chemistry of Minerals 1995, 22, 200-206.

[13] C. Greaves and M. A. Thomas, Acta Crystallographica Section B-Structural Science 1986, 42, 51-55.

[14] V. Rives, Layered Double Hydroxides: Present and Future, Nova Science Publisher, Inc, New York, 2001.

[15] I. Rousselot, C. Taviot-Guého, F. Leroux, P. Léone, P. Palvadeau and J.-P. Besse, Journal of Solid State Chemistry 2002, 167, 137-144.

[16] A. S. Bookin and V. A. Drits, Clays and Clay Minerals 1993, 41, 551-557.

[17] A. S. Bookin, V. I. Cherkashin and V. A. Drits, Clays and Clay Minerals 1993, 41, 558564.

[18] M. Sacerdoti and E. Passaglia, Neues Jahrbuch fur Mineralogie, Monatshefte 1988, 462-475.

[19] M. Bellotto, B. Rebours, O. Clause and J. Lynch, Journal of Physical Chemistry 1996, 100, 8527-8534.

[20] S. M. Auerbach, K. Carrado and P. K. Dutta, Handbook of Layered Materials, Marcel Dekker, Inc., New York, 2004.

[21] F. M. Labajos, V. Rives and M. A. Ulibarri, Spectroscopic Letters 1991, 24, 499-508.

[22] Z. P. Xu and H. C. Zeng, The Journal of Physical Chemistry B 2001, 105, 1743-1749.

[23] G. W. Brindley and S. Kikkawa, Clays and Clay Minerals 1980, 28, 87-91.

[24] M. Borja and P. K. Dutta, The Journal of Physical Chemistry 1992, 96, 5434-5444.

[25] M. Meyn, K. Beneke and G. Lagaly, Inorganic Chemistry 1990, 29, 5201-5207.

[26] S. W. Rhee, M. J. Kang, H. Kim and C. H. Moon, Environmental Technology 1997, 18, 231-236.

[27] H. Nakayama, A. Hatakeyama and M. Tsuhako, International Journal of

Pharmaceutics 2010, 393, 104-111.

[28] Y. Chen, F. Li, G. Yu and J. Wei, Spectrochimca Acta A: Molecular and Biomolecular Spectroscopy 2012, 96, 1005-1011.

[29] M. C. Gastuche, G. Brown and M. M. Mortland, Clay Minerals 1967, 7, 177-192. 
[30] V. Tóth, M. Sipiczki, A. Pallagi, A. Kukovecz, Z. Kónya, P. Sipos and I. Pálinkó, Chemical Papers 2014, 68, 633-637.

[31] S. P. Rosenberg, D. J. Wilson and C. A. Heath in Some aspects of calcium chemistry in the Bayer process, Vol. 192001.

[32] S. P. Rosenberg and L. Armstrong in Layered Double Hydroxides in the Bayer Process: Past, Present and Future, Vol. 157 (Ed. K. Halvor), 2005, pp. 157-161.

[33] E. H. Swanson, H. F. Mcmurdie, M. C. Morris, E. H. Evans, B. Paretzkin, J. H. D. Groot and S. J. Carmel, Nbs Monograph 1972.

[34] S. V. Prasanna, P. V. Kamath and C. Shivakumara, Materials Research Bulletin 2007, 42, 1028-1039.

[35] M. Sipiczki, D. F. Srankó, Á. Kukovecz, Z. Kónya, P. Sipos and I. Pálinkó, Chemical Papers 2011, 65, 840-846.

[36] M. Sipiczki, A. A. Ádám, T. Anitics, Z. Csendes, G. Peintler, Á. Kukovecz, Z. Kónya, P. Sipos and I. Pálinkó, Catalysis Today 2015, 241, 231-236.

[37] S. Velu, V. Ramaswamy, A. Ramani, B. M. Chanda and S. Sivasanker, Chemical Communications 1997, 2107-2108.

[38] S. Velu, K. Suzuki, T. Osaki, F. Ohashi and S. Tomura, Materials Research Bulletin 1999, 34, 1701-1717.

[39] S. Velu, K. Suzuki, M. P. Kapoor and S. O. Tomura, F. Osaki, T., Chemistry of Materials 2000, 12, 719-730.

[40] S. Velu, K. Suzuki and T. Osaki, Catalysis Letters 2000, 69, 43-50.

[41] M. Intissar, J. C. Jumas, J.-P. Besse and F. Leroux, Chemistry of Materials 2003, 15, 4625-4632.

[42] M. Intissar, V. Briois, J. P. Besse and F. Leroux, Physica Scripta 2005, T115, 288-290.

[43] Z. Q. Yang and S. E. Park, Solid State Phenomena 2007, 119, 163-166.

[44] D. S. Tong, C. H. Zhou, M. Y. Li, W. H. Yu, J. Beltramini, C. X. Lin and Z. P. Xu, Applied

Clay Science 2010, 48, 569-574.

[45] 0. Saber, Journal of Physics: Conference Series 2007, 61, 825-830.

[46] A. I. Al Jaafari, American Journal of Applied Sciences 2010, 7, 171-177.

[47] C. Jimenez-Sanchidrian, J. M. Hidalgo, R. Llamas and J. R. Ruiz, Applied Catalysis aGeneral 2006, 312, 86-94.

[48] M. P. Kapoor and Y. Matsumura, Catalysis Today 2004, 93-95, 287-291.

[49] X. Zheng and P. A. Cusack, Fire and Materials 2011, 37, 35-45.

[50] W. T. Reichle, Solid State Ionics 1986, 22, 135-141.

[51] W. H. R. Shaw and J. J. Bordeaux, Journal of the American Chemical Society 1955, 77, 4729-4733.

[52] J. J. Bravo-Suarez, E. A. Páez-Mozo and S. T. Oyama, Quimica Nova 2004, 27, 601614.

[53] M. Adachi-Pagano, C. Forano and J. P. Besse, Journal of Materials Chemistry 2003, 13, 1988-1993.

[54] M. Ogawa and H. Kaiho, Langmuir 2002, 18, 4240-4242.

[55] N. Morel-Desrosiers, J. Pisson, Y. Israeli, C. Taviot-Gueho, J. P. Besse and J. P. Morel, Journal of Materials Chemistry 2003, 13, 2582-2585.

[56] Y. Israëli, C. Taviot-Guého, J.-P. Besse, J.-P. Morel and N. Morel-Desrosiers, Journal of the Chemical Society, Dalton Transactions 2000, 791-796.

[57] S. Miyata, Clays and Clay Minerals 1983, 31, 305-311.

[58] T. Yamaoka, M. Abe and M. Tsuji, Materials Research Bulletin 1989, 24, 1183-1199.

[59] S. P. Newman and W. Jones, New Journal of Chemistry 1998, 22, 105-115. 
[60] R. K. Kukkadapu, M. S. Witkowsky and J. E. Amonette, Chemistry of Materials 1997, 9, 417-419.

[61] S. Miyata, Clays and Clay Minerals 1980, 28, 50-56.

[62] T. Hibino and A. Tsunashima, Chemistry of Materials 1998, 10, 4055-4061.

[63] J. S. Valente, G. Rodriguez-Gattorno, M. Valle-Orta and E. Torres-Garcia, Materials

Chemistry and Physics 2012, 133, 621-629.

[64] C. O. Oriakhi, I. V. Farr and M. M. Lerner, Clays and Clay Minerals 1997, 45, 194-202.

[65] M. Ogawa and S. Asai, Chemistry of Materials 2000, 12, 3253-3255.

[66] M. A. Aramendia, V. Borau, C. Jiménez, J. M. Marinas, J. R. Ruiz and F. J. Urbano, Journal of Solid State Chemistry 2002, 168, 156-161.

[67] Y. Zhao, F. Li, R. Zhang, D. G. Evans and X. Duan, Chemistry of Materials 2002, 14, 4286-4291.

[68] H.-P. Boehm, J. Steinle and C. Vieweger, Angewandte Chemie International Edition in English 1977, 16, 265-266.

[69] L. Indira, M. Dixit and P. V. Kamath, Journal of Power Sources 1994, 52, 93-97.

[70] G. Hu and D. O'Hare, J Am Chem Soc 2005, 127, 17806-17813.

[71] V. R. Khusnutdinov and V. P. Isupov, Chemistry for Sustainable Development 2007, 15, 367-372.

[72] W. Tongamp, Q. Zhang and F. Saito, Journal of Materials Science 2007, 42, 9210-

9215.

[73] D. Braga, S. L. Giaffreda, F. Grepioni, A. Pettersen, L. Maini, M. Curzi and M. Polito, Dalton Transactions 2006, 1249-1263.

[74] A. N. Ay, B. Zümreoglu-Karan and L. Mafra, Zeitschrift für Anorganische und Allgemeine Chemie 2009, 635, 1470-1475.

[75] M. Milanesio, E. Conterosito, D. Viterbo, L. Perioli and G. Croce, Crystal Growth \& Design 2010, 10, 4710-4712.

[76] A. Hayashi and H. Nakayama, Chemistry Letters 2010, 39, 1060-1062.

[77] E. Conterosito, W. Van Beek, L. Palin, G. Croce, L. Perioli, D. Viterbo, G. Gatti and M. Milanesio, Crystal Growth \& Design 2013, 13, 1162-1169.

[78] F. Zhang, N. Du, S. Song and W. Hou, Materials Chemistry and Physics 2015, 152, 95103.

[79] F. Zhang, N. Du, S. Song, J. Liu and W. Hou, Journal of Solid State Chemistry 2013, 206, 45-50.

[80] L. Takacs, Chemical Society Reviews 2013, 42, 7649-7659.

[81] P. Baláz, Mechanochemistry in nanoscience and minerals engineering, Springer, Kosice, Slovakia, 2008.

[82] L. Takacs, Journal of Thermal Analysis and Calorimetry 2007, 90, 81-84.

[83] L. H. Parker, Journal of the Chemical Society 1918, 113, 396-409.

[84] C. Suryanarayana, Progress in Materials Science 2001, 46, 1-184.

[85] F. P. Bowden and A. D. Yoffe, Initiation and Growth of Explosion in Liquids and Solids, Cambridge University Press, Cambridge, UK, 1985.

[86] V. V. Boldyrev, Bulletin of the Academy of Sciences of the Ussr Division of Chemical Science 1990, 39, 2029-2044.

[87] P. A. Thiessen , K. Meyer and G. Heinicke, Grundlagen der Tribochemie, Akademie Verlag, Berlin, 1967

[88] H. Heegn, Izvestiya Sibirskogo Otdeleniya Akademii Nauk Sssr Seriya Khimicheskikh Nauk 1988, 3-9.

[89] Strelets.An and P. Y. Butyagin, Vysokomolekulyarnye Soedineniya Seriya A 1973, 15, 654-661. 
[90] V. V. Boldyrev, Thermochimica Acta 1987, 110, 303-317.

[91] K. Tkacova, P. Balaz and Z. Bastl, Thermochimica Acta 1990, 170, 277-288.

[92] A. Smekal, Naturwissenschaften 1942, 30, 224-225.

[93] P. Y. Butyagin, Uspekhi Khimii 1984, 53, 1769-1789.

[94] A. Z. Juhasz and B. Kollath, Acta Chimica Hungarica-Models in Chemistry 1993, 130, 725-735.

[95] F. Toda, K. Tanaka and A. Sekikawa, Journal of the Chemical Society, Chemical Communications 1987, 279-280.

[96] L. Opoczky, Powder Technology 1977, 17, 1-7.

[97] G. Bettinetti, M. R. Caira, A. Callegari, M. Merli, M. Sorrenti and C. Tadini, Journal of Pharmaceutical Sciences 2000, 89, 478-489.

[98] Y. A. Kim, T. Hayashi, Y. Fukai, M. Endo, T. Yanagisawa and M. S. Dresselhaus, Chemical Physics Letters 2002, 355, 279-284.

[99] G. Bruni, A. Marini, V. Berbenni, R. Riccardi and M. Villa, Journal of Inclusion Phenomena and Macrocyclic Chemistry 1999, 35, 517-530.

[100] F. Taneri, T. Guneri, Z. Aigner and M. Kata, Journal of Inclusion Phenomena and Macrocyclic Chemistry 2002, 44, 257-260.

[101] R. Saikosin, T. Limpaseni and P. Pongsawasdi, Journal of Inclusion Phenomena and Macrocyclic Chemistry 2002, 44, 191-196.

[102] D. Braga and F. Grepioni, Angewandte Chemie-International Edition 2004, 43, 4002-4011.

[103] R. P. Rastogi, P. S. Bassi and S. L. Chadha, The Journal of Physical Chemistry 1963, 67, 2569-2573.

[104] V. V. Boldyrev, Russian Chemical Reviews 2006, 75, 177-190.

[105] G. Kaupp, Organic Solid State Reactions 2005, 254, 95-183.

[106] J. Schmeyers, F. Toda, J. Boy and G. Kaupp, Journal of the Chemical Society-Perkin

Transactions 2 1998, 989-993.

[107] G. Cevasco and S. Thea, Journal of Organic Chemistry 1999, 64, 5422-5426.

[108] G. W. Wang, K. Komatsu, Y. Murata and M. Shiro, Nature 1997, 387, 583-586.

[109] Y. Murata, N. Kato and K. Komatsu, Journal of Organic Chemistry 2001, 66, 72357239.

[110] D. N. B. Tichit, M.; Figueras, F.; Tessier, R.; Kervennal, J., Applied Clay Science 1998, 13, 401-415.

[111] K. K. Rao, M. Gravelle, J. S. Valente and F. Figueras, Journal of Catalysis 1998, 173, 115-121.

[112] S. Ueno, K. Yoshida, K. Ebitani and K. Kaneda, Chemical Communications 1998, 295-296.

[113] E. Suzum, M. Okamoto and Y. Ono, Journal of Molecular Catalysis 1990, 61, 283294.

[114] K. Zhu, C. Liu, X. Ye and Y. Wu, Applied Catalysis A: General 1998, 168, 365-372.

[115] B. M. Choudary, M. Lakshmi Kantam, C. R. Venkat Reddy, K. Koteswara Rao and F.

Figueras, Journal of Molecular Catalysis A: Chemical 1999, 146, 279-284.

[116] B. M. Choudary, M. Lakshmi Kantam, C. Venkat Reddy, S. Aranganathan, P. Lakshmi Santhi and F. Figueras, Journal of Molecular Catalysis A: Chemical 2000, 159, 411-416. [117] B. F. Sels, D. E. De Vos and P. A. Jacobs, Catalysis Reviews 2001, 43, 443-488. [118] E. Iglesia, D. G. Barton, J. A. Biscardi, M. J. L. Gines and S. L. Soled, Catalysis Today 1997, 38, 339-360.

[119] V. R. L. Constantino and T. J. Pinnavaia, Inorganic Chemistry 1995, 34, 886-892. 
[120] Z. P. Xu, J. Zhang, M. O. Adebajo, H. Zhang and C. Zhou, Applied Clay Science 2011, $53,139-150$.

[121] Y. Z. Chen, C. M. Hwang and C. W. Liaw, Applied Catalysis A: General 1998, 169, 207-214.

[122] T. H. Bennur, A. Ramani, R. Bal, B. M. Chanda and S. Sivasanker, Catalysis

Communications 2002, 3, 493-496.

[123] B. M. Choudary, S. Madhi and N. S. Chowdari, Journal of the American Chemical Society 2002, 124, 14127-14136.

[124] P. Levecque, H. Poelman, P. Jacobs, D. De Vos and B. Sels, Physical Chemistry Chemical Physics 2009, 11, 2964-2975.

[125] B. M. Choudary, C. V. Reddy, B. V. Prakash, B. Bharathi and M. L. Kantam, Journal of Molecular Catalysis A: Chemical 2004, 217, 81-85.

[126] H. S. Shin, M. J. Kim, S. Y. Nam and H. C. Moon, Water Science and Technology 1996, 34, 161-168.

[127] M. Park, C. I. Lee, Y. J. Seo, S. R. Woo, D. Shin and J. Choi, Environmental Sciences and Pollution Research International 2010, 17, 203-209.

[128] Y. Seida and Y. Nakano, Water Research 2000, 34, 1487-1494.

[129] Y. Ding and E. Alpay, Process Safety and Environmental Protection 2001, 79, 45-51.

[130] U. Costantino, V. Ambrogi, M. Nocchetti and L. Perioli, Microporous and Mesoporous Materials 2008, 107, 149-160.

[131] A. I. Khan, L. X. Lei, A. J. Norquist and D. O'Hare, Chemical Communications 2001, 2342-2343.

[132] J. H. Choy, J. S. Jung, J. M. Oh, M. Park, J. Jeong, Y. K. Kang and O. J. Han, Biomaterials 2004, 25, 3059-3064.

[133] S. Y. Kwak, W. M. Kriven, M. A. Wallig and J. H. Choy, Biomaterials 2004, 25, 59956001.

[134] J. H. Choy, S. Y. Kwak, J. S. Park and Y. J. Jeong, Journal of Materials Chemistry 2001, 11,1671-1674.

[135] J. H. Choy, S. Y. Kwak, J. S. Park, Y. J. Jeong and J. Portier, Journal of the American Chemical Society 1999, 121, 1399-1400.

[136] J. H. Choy and Y. H. Son, Bulletin of the Korean Chemical Society 2004, 25, 122-126. [137] S. H. Hwang, Y. S. Han and J. H. Choy, Bulletin of the Korean Chemical Society 2001, 22, 1019-1022.

[138] M. Z. bin Hussein, Z. Zainal, A. H. Yahaya and D. W. V. Foo, Journal of Controlled Release 2002, 82, 417-427.

[139] J. H. Yang, S. Y. Lee, Y. S. Han, K. C. Park and J. H. Choy, Bulletin of the Korean Chemical Society 2003, 24, 499-503.

[140] J. C. Buffet, N. Wanna, T. A. Q. Arnold, E. K. Gibson, P. P. Wells, Q. Wang, J. Tantirungrotechai and D. O'Hare, Chemistry of Materials 2015, 27, 1495-1501.

[141] T. Challier and R. C. T. Slade, Journal of Materials Chemistry 1994, 4, 367-371.

[142] S. O'Leary, D. O'Hare and G. Seeley, Chemical Communications 2002, 1506-1507.

[143] F. Leroux and J.-P. Besse, Chemistry of Materials 2001, 13, 3507-3515.

[144] G. Camino, A. Maffezzoli, M. Braglia, M. De Lazzaro and M. Zammarano, Polymer Degradation and Stability 2001, 74, 457-464.

[145] J. X. Zhu, P. Yuan, H. P. He, R. Frost, Q. Tao, W. Shen and T. Bostrom, Journal of Colloid and Interface Science 2008, 319, 498-504.

[146] P. M. Sipos, G. Hefter and P. M. May, Journal of Chemical and Engineering Data 2000, 45, 613-617. 
[147] S. Carlson, M. Clausen, L. Gridneva, B. Sommarin and C. Svensson, Journal of Synchrotron Radiation 2006, 13, 359-364.

[148] B. Ravel and M. Newville, Journal of Synchrotron Radiation 2005, 12, 537-541.

[149] J. J. Rehr, J. Mustre de Leon, S. I. Zabinsky and R. C. Albers, Journal of the American Chemical Society 1991, 113, 5135-5140.

[150] P. Fornasini in Introduction to X-Ray Absorption Spectroscopy, Vol. Eds.: S. Mobilio, F. Boscherini and C. Meneghini), Springer Berlin Heidelberg, 2015, pp. 181-211.

[151] Y. Wang, S. Luo, Z. Wang and Y. Fu, Applied Clay Science 2013, 80-81, 334-339.

[152] G. Renaudin, M. Francois and O. Evrard, Cement and Concrete Research 1999, 29, 63-69.

[153] C. R. Hubbard, E. H. Evans and D. K. Smith, Journal of Applied Crystallography 1976, 9, 169-174.

[154] T. E. Westre, P. Kennepohl, J. G. DeWitt, B. Hedman, K. O. Hodgson and E. I. Solomon, Journal of the American Chemical Society 1997, 119, 6297-6314.

[155] V. Prevot, V. Briois, J. Cellier, C. Forano and F. Leroux, Journal of Physics and Chemistry of Solids 2008, 69, 1091-1094.

[156] J. J. P. Stewart, Journal of Computational Chemistry 1989, 10, 209-220.

[157] J. J. P. Stewart, Journal of Computational Chemistry 1989, 10, 221-264. 


\section{MAGYAR ÖSSZEFOGLALÓ (SUMmARY IN HUNGARIAN)}

A réteges kettős hidroxidok (LDH-k) anioncserélő tulajdonságuknak köszönhetően egy egyedi csoportot alkotnak az agyagásvány-szerű anyagok között. Szerkezetileg brucit jellegű rétegekből állnak, melyekben a kétértékű fémiont izomorf módon háromértékű fémion helyettesíti, ezzel többlet pozitív töltéssel ruházva fel a rétegeket. A rétegek között töltéskompenzáló anionok, illetve vízmolekulák helyezkednek el, így biztosítva a töltéssemlegességet. Ezek az anyagok ugyan előfordulnak a természetben, de ha fel akarják használni őket, akkor inkább szintézisük jön szóba. Szintetikus előállításukra leggyakrabban oldatkémiai módszereket használnak (együttes lecsapás, hidrolízis karbamid jelenlétében, stb.)

Munkám során a CaSn-, CaAl- és CaFe-LDH-k szintézisére és interkalálására egy kevésbé elterjedt módszert használtam, a mechanokémiát. Az előállított anyagokat különböző szerkezetvizsgálati módszerek segítségével vizsgáltam, úgymint (por)röntgendiffraktometria (XRD), infravörös spektroszkópia (IR), termogravimetria (TG/dTG), röntgenabszorpciós spektroszkópia (XAS), pásztázó elektronmikroszkópia (SEM) és energiadiszperzív röntgenanalízis (SEM-EDX).

A kísérletek során bebizonyosodott, hogy a mechanokémia egy járható út az LDH-k szintézisében. Továbbá ezt a módszert alkalmazva sikerült előállítani a Ca(II)Sn(IV)LDH-t, melynek szintézise kudarcba fulladt a klasszikus, oldatfázisú szintézismódszerek alkalmazásakor. Ugyanakkor sikerült bebizonyítani, hogy elő lehet állítani Sn(IV)fémiont a rétegekben tartalmazó réteges kettős hidroxidot (melyek létezéséről komoly vita volt a szakirodalomban). Az itt is alkalmazott kétlépéses őrlési módszer optimalizálását elvégeztük a $\mathrm{Ca}(\mathrm{II}) \mathrm{Al}(\mathrm{III})$ és a $\mathrm{Ca}(\mathrm{II}) \mathrm{Fe}(\mathrm{III})$ rendszereken is. Mindkét esetben a reakcióparaméterek szisztematikus változtatásával meghatároztuk az optimális reakciókörülményeket, melyek használatával sikerült közel fázistiszta anyagokat előállítani. Kiderült, hogy a víz hozzáadásának kulcsfontosságú szerepe van a szintézis során, ugyanakkor a legnagyobb hatással rendelkező paraméter a közölt mechanokémia energia, amelyet golyó/minta tömegaránnyal tudtam szabályozni. Az XRD eredmények minden esetben rendezett réteges szerkezettel rendelkező anyagokra utaltak. Továbbá a TG, SEM és SEM-EDX mérések is LDH-ra jellemző eredményeket mutattak. A Ca(II)Fe(III) rendszerben mért EXAFS adatok alapján kiderült, hogy a vas első koordinációs szférájában hat oxigénatom található 1,99 Å hosszú Fe-0 interatomos 
távolsággal, továbbá a második koordinációs szférában három Ca²+-ion található 3,12 hosszú $\mathrm{Fe}-\mathrm{Ca}$ interatomos távolsággal, illetve három $\mathrm{Ca}^{2+}$-ion 3,55 Å hosszú $\mathrm{Fe}-\mathrm{Ca}$ interatomos távolsággal. Ezek az adatok szintén az LDH-ra jellemezőek.

A CaSn és a CaFe rendszerek esetében mechanokémiai módszerekkel aminosavak (cisztin, tirozin, és valin) anionjainak interkalációjára tettünk kísérletet. A Ca(II)Sn(IV)LDH-k esetében bebizonyosodott, hogy a mechanokémiai módszer alkalmazásával megvalósítható nagyobb szerves anion interkalációja. Az interkalációs eljárás optimalizálására a kismértékben módosított kétlépéses őrlési módszert, illetve a Ca(II)Fe(III) rendszert használtuk. Az eredmények alapján kijelenthetô, hogy a cisztináttal interkalált LDH és a szervetlen anionokkal interkalált LDH kialakulása egymással verseng. Ugyanakkor a tirozinát anion könnyen interkalálódik a rétegek közé. $\mathrm{Az}$ interkaláció tényét megerősítették az XRD, IR SEM és EDX eredmények is. A röntgenabszorpciós mérések szerint az LDH rétegeit nem károsította az interkalációs reakció, hiszen a mérések eredményei a már előbb említett LDH-ra jellemző adatok voltak. Ismerve az aminosav anionok méreteit (a PM3 szemiempirikus számítások alapján), illetve a rétegtávolság változást (XRD eredmények alapján) becslést lehetett adni az anionok rétegek közötti orientációjára. A cisztinát anionok orientációja kétréteges elhelyezkedést mutat, ahol az anionok párhuzamosan helyezkednek el a réteghez képest. A tirozinát anionok esetében szintén feltételezhető egy hasonló elrendeződés, valamint egy olyan orientáció is, ahol az anion merőlegesen helyezkedik el a réteghez képest.

Az előbbi eredmények egyértelműen bizonyítják, hogy a mechanokémia egy működőképes alternatíva mind az LDH-k szintézisében, mind az interkalációjában. A reakcióparaméterek optimalizálásával elő lehet állítani közel fázistiszta LDH-kat, valamint különböző szerves anionok interkalációja is megvalósítható. A mechanokémiai módszerrel továbbá előállíthatók olyan „egzotikus” LDH-k melyek szintézise akadályba ütközött klasszikus, oldatfázisú előállítási módszerek alkalmazásával. 


\section{ACKNOWLEDGEMENT}

Firstly, I want to gratefully thank Drs. István Pálinkó and Pál Sipos for their immense support and help throughout the years I have spent in Szeged for both theoretical and practical encouragement and teaching.

Let me also gratefully acknowledge Dr. Gábor Peintler for his excellent advices and detailed review of my thesis, and also of the occurring problems during my PhD studies. I also want to thank all former and current members of the Material and Solution Structure Research Group, for both their professional help, collaboration and none the less their friendship.

Finally, I want to thank my family and my friends for their immense support during my studies.

The expenses of the experimental work were covered by the OTKA NKFI 106234 grant. The financial help is highly appreciated. 